Nevada

Environmental

Restoration

Project

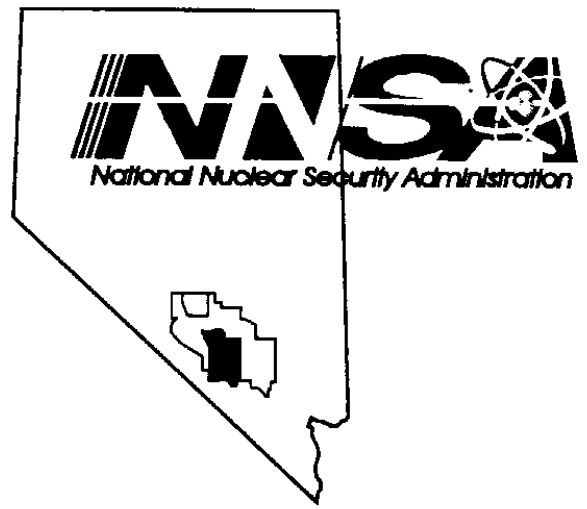

Closure Report for Corrective

Action Unit 396: Area 20 Spill

Sites, Nevada Test Site, Nevada

Controlled Copy No.:

Revision: 0

June 2004

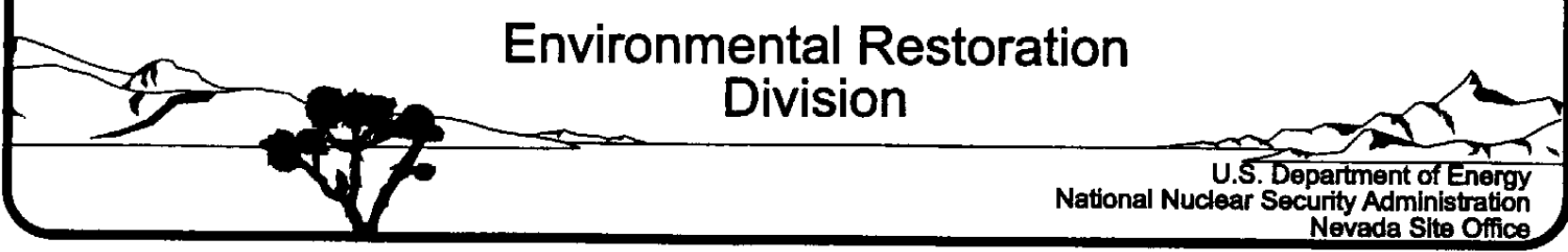




\section{DISCLAIMER}

Reference herein to any specific commercial product, process, or service by trade name, trademark, manufacturer, or otherwise, does not necessarily constitute or imply its endorsement, recommendation, or favoring by the U.S. Government or any agency thereof or its contractors or subcontractors.

This report has been reproduced directly from the best available copy.

Available for sale to the public from:

U.S. Department of Commerce

National Technical Information Service

5285 Port Royal Road

Springfield, VA 22161-0002

Telephone: (800) 553-6847

Fax: (703) 605-6900

E-mail: orders@ntis.gov

Online ordering: http://www.ntis.gov/ordering.htm

Available electronically at http://www.osti.gov/bridge.

Available for a processing fee to the U.S. Department of Energy and its contractors, in paper, from:

U.S. Department of Energy

Office of Scientific and Technical Information

P.O. Box 62

Oak Ridge, TN 37831-0062

Telephone: (865) 576-8401

Fax: (865) 576-5728

E-mail: reports@adonis.osti.gov 


\title{
CLOSURE REPORT FOR CORRECTIVE ACTION UNIT 396: AREA 20 SPILL SITES, NEVADA TEST SITE, NEVADA
}

\author{
Prepared for: \\ U.S. Department of Energy \\ National Nuclear Security Administration \\ Nevada Site Office \\ Work Performed Under Contract No. DE-AC08-96NV11718
}

Controlled Copy No.

Revision: 0

June 2004 
THIS PAGE INTENTIONALLY LEFT BLANK 


\section{SAFER CLOSURE REPORT FOR CORRECTIVE ACTION UNIT 396: AREA 20 SPILL SITES, NEVADA TEST SITE, NEVADA}

\footnotetext{
Approved By: SIGNATURE APPROVED

Date: $\quad 6 / 16 / 04$

Janet Appenzeller-Wing, Project Manager

Industrial Sites Project

Approved By: SIGNATURE APPROVED

Date: $6 / 16 / 04$

Monica Sanchez, Acting Director

Environmental Restoration Division
} 
THIS PAGE INTENTIONALLY LEFT BLANK 


\section{TABLE OF CONTENTS}

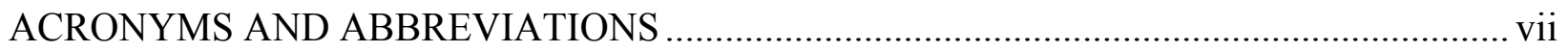

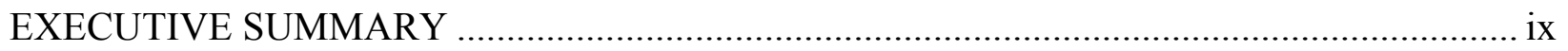

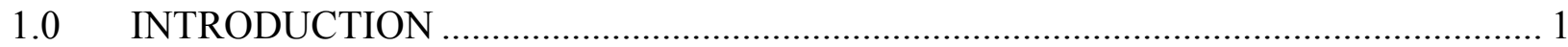

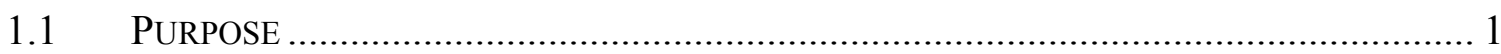

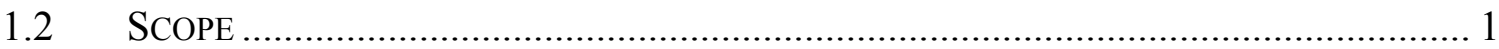

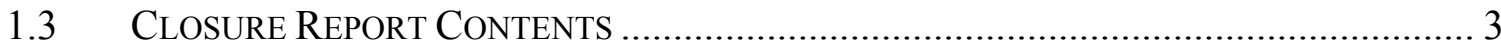

1.3.1 Data Quality Objectives........................................................................... 4

2.0 CLOSURE ACTIVITIES ………………………………………………………... 5

2.1 DESCRIPTION OF CORRECTIVE ACTION ACTIVITIES ........................................... 5

2.1.1 Preplanning and Site Preparation........................................................ 5

2.1.2 Summary of CAU 396 Site History ............................................................ 5

2.1.3 Summary of CAU 396 Site Characterization Activities and Results ......... 6

2.1.4 CAS 20-25-01, Oil Spills (2) Closure Activities ....................................... 6

2.1.5 CAS 20-25-02, Oil Spills Closure Activities........................................... 7

2.1.6 CAS 20-25-03, Oil Spill Closure Activities ………............................... 7

2.1.7 CAS 20-99-08, Spill Closure Activities.................................................... 8

2.2 DEVIATIONS FROM SAFER PLAN AS APPROVED................................................... 8

2.3 CORRECTIVE ACTION SCHEDULE AS COMPLETED ……............................................ 8

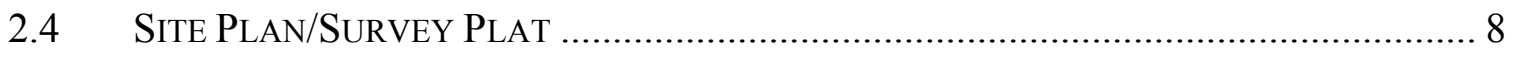

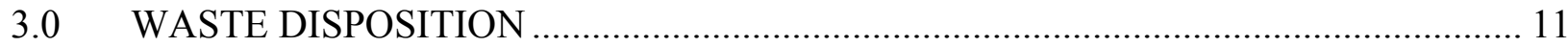

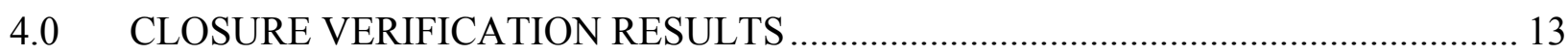

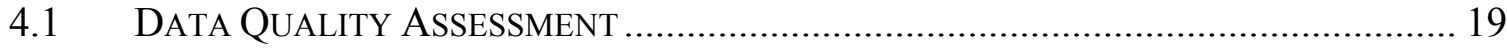

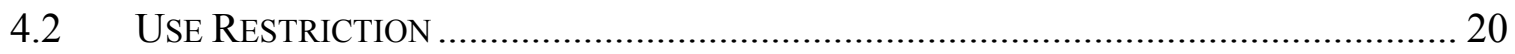

5.0 CONCLUSIONS AND RECOMMENDATIONS ……................................................... 21

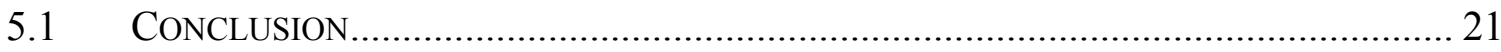

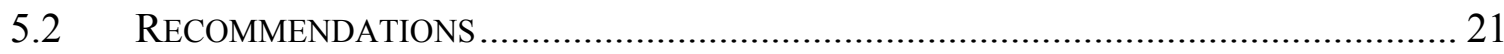

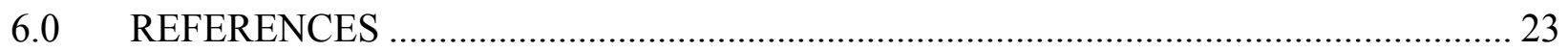




\section{TABLE OF CONTENTS (continued)}

\section{FIGURES}

FIGURE 1 CAU 396: AREA 20 SPILL SITES - SITE LOCATION MAP .............................. 2

FIGURE 2 CAS 20-25-1, OIL SPILLS (2), VERIFICATION SAMPLE LOCATIONS ........... 14

FIGURE 3 CAS 20-25-02 OIL SPILLS, VERIFICATION SAMPLE LOCATIONS................ 15

FIGURE 4 CAS 20-25-03, OIL SPILL, VERIFICATION SAMPLE LOCATIONS ................. 16

\section{TABLES}

TABLE 1: CORRECTIVE ACTION SCHEDULE AS COMPLETED ................................. 9

TABLE 2: TPH WASTE QUANTITIES GENERATED DURING CLOSURE OF CAU 396. 11

TABLE 3: CAU 396 VERIFICATION SAMPLE RESULTS

\section{APPENDICES}

APPENDIX A - DATA QUALITY OBJECTIVES FOR CAU 396

APPENDIX B - CLOSURE CERTIFICATION

APPENDIX C - AS BUILT DOCUMENTATION

APPENDIX D - SAMPLE ANALYTICAL RESULTS

APPENDIX E - WASTE DISPOSITION DOCUMENTATION

APPENDIX F - MODIFICATIONS

APPENDIX G - PHOTOGRAPHS OF CLOSURE ACTIVITIES

LIBRARY DISTRIBUTION LIST 


\section{ACRONYMS AND ABBREVIATIONS}

\begin{tabular}{|c|c|}
\hline bgs & below ground surface \\
\hline BMP & Best Management Practice \\
\hline $\mathrm{BN}$ & Bechtel Nevada \\
\hline CAS & Corrective Action Site \\
\hline CAU & Corrective Action Unit \\
\hline $\mathrm{COC}$ & Contaminant(s) of concern \\
\hline COPC & Contaminant(s) of potential concern \\
\hline $\mathrm{CR}$ & Closure Report \\
\hline CSM & Conceptual Site Model \\
\hline DOE & U.S. Department of Energy \\
\hline DOE/NV & U.S. Department of Energy, Nevada Operations Office \\
\hline DQO & Data Quality Objectives \\
\hline EPA & U.S. Environmental Protection Agency \\
\hline $\mathrm{ft}$ & foot (feet) \\
\hline $\mathrm{ft}^{3}$ & cubic foot (feet) \\
\hline FFACO & Federal Facility Agreement and Consent Order \\
\hline IT & International Technology Corporation \\
\hline $\mathrm{m}$ & meter(s) \\
\hline $\mathrm{m}^{3}$ & cubic meter(s) \\
\hline $\mathrm{mg} / \mathrm{kg}$ & milligram(s) per kilogram \\
\hline NAC & Nevada Administrative Code \\
\hline NDEP & Nevada Division of Environmental Protection \\
\hline NNSA/NSO & $\begin{array}{l}\text { U.S. Department of Energy, National Nuclear Security Administration } \\
\text { Nevada Site Office }\end{array}$ \\
\hline $\mathrm{NNSA} / \mathrm{NV}$ & $\begin{array}{l}\text { U.S. Department of Energy, National Nuclear Security Administration } \\
\text { Nevada Operations Office }\end{array}$ \\
\hline NTS & Nevada Test Site \\
\hline PA & preliminary assessment \\
\hline PCB & polychlorinated biphenyl(s) \\
\hline $\mathrm{pCi} / \mathrm{g}$ & picoCuries(s) per gram \\
\hline $\mathrm{PRG}$ & Preliminary Remediation Goal(s) \\
\hline RCRA & Resource Conservation and Recovery Act \\
\hline RSN & Raytheon Services Nevada \\
\hline SAFER & Streamlined Approach For Environmental Restoration \\
\hline SDG & Sample Delivery Group \\
\hline SVOC & Semivolatile organic compound(s) \\
\hline $\mathrm{TPH}$ & Total Petroleum Hydrocarbon(s) \\
\hline $\mathrm{yd}^{3}$ & cubic yard(s) \\
\hline VOC & Volatile organic compound(s) \\
\hline$\mu \mathrm{g} / \mathrm{kg}$ & microgram(s) per kilogram \\
\hline
\end{tabular}


CLOSURE REPORT - CAU 396

Section: Acronyms \& Abbreviations

Revision: 0

Date: June 2004

THIS PAGE LEFT INTENTIONALLY BLANK 


\section{EXECUTIVE SUMMARY}

Corrective Action Unit (CAU) 396, Area 20 Spill Sites, is located on the Nevada Test Site (NTS) approximately 105 kilometers (65 miles) northwest of Las Vegas, Nevada. CAU 396 is listed in Appendix III of the Federal Facility Agreement and Consent Order (FFACO) of 1996 and consists of the following four Corrective Action Sites (CASs) located in Area 20 of the NTS:

- CAS 20-25-01, Oil Spills (2)

- CAS 20-25-02, Oil Spills

- CAS 20-25-03, Oil Spill

- CAS 20-99-08, Spill

Closure activities for CAU 396 were conducted in accordance with the FFACO and the Nevada Division of Environmental Protection-approved Streamlined Approach for Environmental Restoration (SAFER) Plan for CAU 396 (U.S. Department of Energy National Nuclear Security Administration, Nevada Site Office, 2003). CAU 396 SAFER closure activities consisted of the following:

- CAS 20-25-01, Oil Spills (2), was clean closed by excavation and disposal of impacted soil. Site characterization results showed that total petroleum hydrocarbons (TPH) was the only contaminant of concern (COC) present above action levels. The site was clean closed by removing and disposing approximately 16 cubic meters $\left(\mathrm{m}^{3}\right)\left(21\right.$ cubic yards $\left.\left[\mathrm{yd}^{3}\right]\right)$ of TPHimpacted soil from two locations. Verification samples were collected from the sidewalls and bottom of the excavations and submitted for TPH analysis. Once analytical results for the verification samples showed TPH concentrations less than 100 milligrams per kilogram $(\mathrm{mg} / \mathrm{kg})$, the excavations were backfilled with native fill.

- CAS 20-25-02, Oil Spills, was clean closed as a best management practice. Site characterization results showed TPH was the only COC present at levels near the action level. The site was closed by removing and disposing of approximately $0.03 \mathrm{~m}^{3}\left(0.04 \mathrm{yd}^{3}\right)$ of soil. Verification samples were collected from the sidewall and bottom of the excavation and submitted for TPH analysis. Once analytical results for the verification samples showed TPH concentrations less than $100 \mathrm{mg} / \mathrm{kg}$, the excavations were backfilled with native fill.

- CAS 20-25-03, Oil Spill, was clean closed by excavation and disposal of impacted soil. Site characterization results showed TPH was the only COC present above action levels. The site was clean closed by removing and disposing of approximately $55.2 \mathrm{~m}^{3}\left(72.6 \mathrm{yd}^{3}\right)$ of TPHimpacted soil from two locations. Verification samples were collected from the sidewalls and bottom of the excavations and submitted for TPH analysis. Once analytical results for the verification samples showed TPH concentrations less than $100 \mathrm{mg} / \mathrm{kg}$, the excavations were backfilled with native fill.

- CAS 20-99-08, Spill, no further action was taken since characterization results indicated no COC present above action levels. 
CLOSURE REPORT - CAU 396

Section: Executive Summary

Revision: 0

Date: June 2004

THIS PAGE LEFT INTENTIONALLY BLANK 


\subsection{INTRODUCTION}

This Closure Report (CR) documents the closure activities performed at Corrective Action Unit (CAU) 396: Area 20 Spill Sites. CAU 396 closure activities were conducted in accordance with the Federal Facility Agreement and Consent Order (FFACO, 1996), and the Nevada Division of Environmental Protection (NDEP) approved Streamlined Approach for Environmental Restoration (SAFER) Plan for CAU 396 (U.S. Department of Energy, National Nuclear Security Administration Nevada Site Office [NNSA/NSO], 2003). CAU 396 is located at the Nevada Test Site (NTS) approximately 105 kilometers (65 miles) northwest of Las Vegas, Nevada (Figure 1). CAU 396 consists of the following 4 Corrective Action Sites (CASs) located in Area 20 of the NTS (Figure 1):

- CAS 20-25-01, Oil Spills (2)

- CAS 20-25-02, Oil Spills

- CAS 20-25-03, Oil Spill

- CAS 20-99-08, Spill

\subsection{Purpose}

CAU 396 is comprised of four CASs located in Area 20 of the NTS. The sites are believed to be associated with historic drilling operations. Three of the CASs were clean closed by removal of impacted soil, and no further action was conducted at the remaining site since no contaminants of concern (COCs) were found to be present above action levels. See Section 2.0 for more details on closure activities.

The purpose of this CR is to document that the closure activities conducted at CAU 396 complied with all of the closure requirements as stated in the NDEP-approved SAFER Plan for CAU 396 (NNSA/NSO, 2003).

\subsection{SCOPE}

Previous site characterization work done in 2003 found no COCs above action levels at two of the CASs (CAS 20-25-02 and CAS 20-99-08), and total petroleum hydrocarbons (TPH) as the only COCs found at concentrations greater than action levels at the remaining CASs (CAS 2025-01 and CAS 20-25-03) (International Technology [IT], 2001).

The closure strategy for CAU 396 was specified in the NDEP-approved SAFER Plan (NNSA/NSO, 2003) as follows:

- CAS 20-25-01, Oil Spills (2) - Clean closure

- CAS 20-25-02, Oil Spills - Clean closure as a best management practice

- CAS 20-25-03, Oil Spill - Clean closure

- CAS 20-99-08, Spill - No further action 


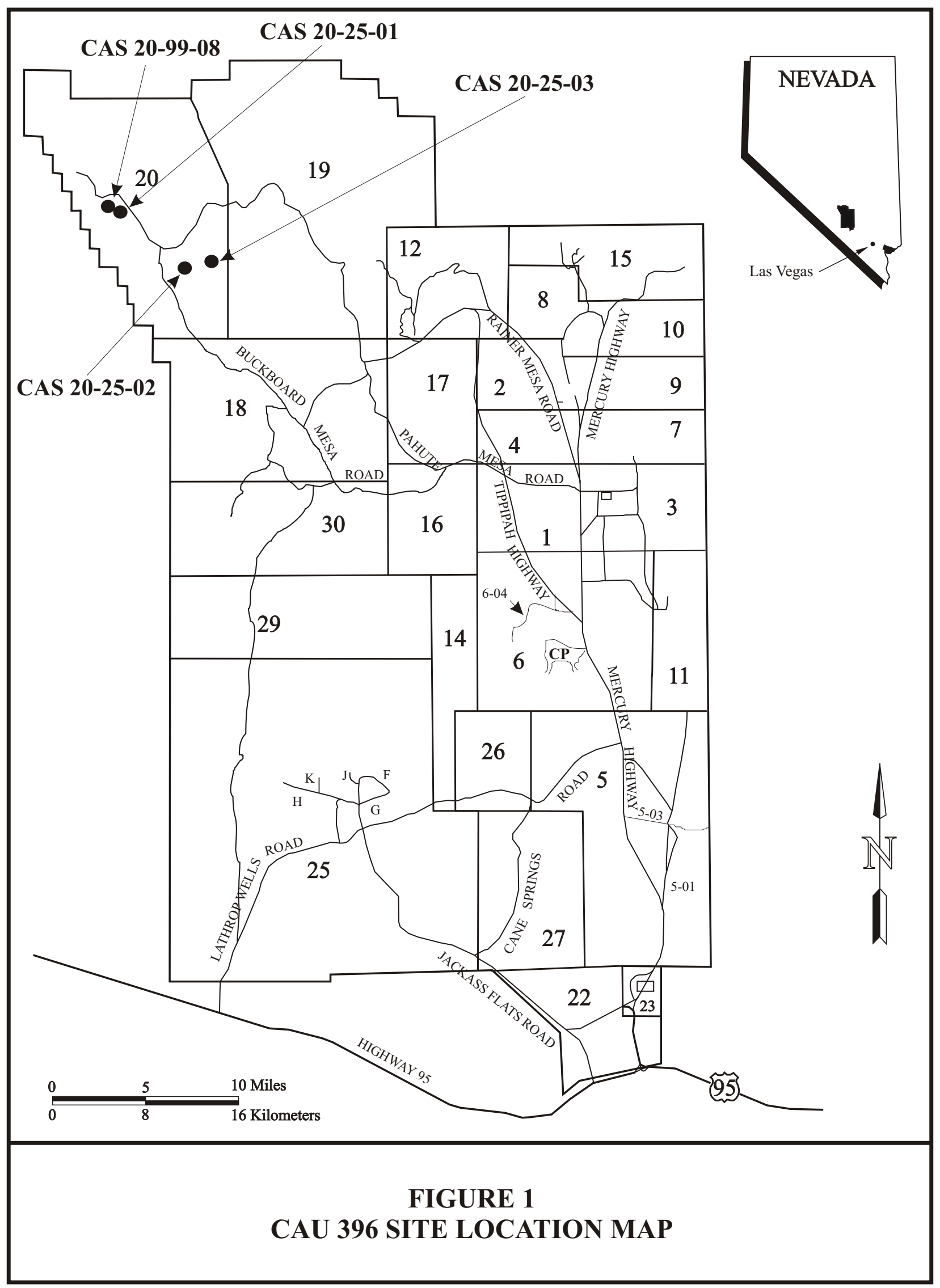


Three CASs were clean closed by removing all TPH-impacted soil and transporting it to the NTS Area 6 Hydrocarbon Landfill for disposal. Soil verification samples were collected from the bottom and sidewalls of the excavations and submitted for laboratory analysis to verify that all soil with TPH concentration greater than the 100 milligrams per kilogram (mg/kg) TPH action level (Nevada Administrative Code [NAC], 2002) has been removed from the sites. The excavations were backfilled with clean fill and returned to the approximate original site grade.

\subsection{Closure Report Contents}

This CR is divided into the following sections:

- Section 1.0 - Introduction

- Section 2.0 - Closure Activities

- Section 3.0 - Waste Disposition

- Section 4.0 - Closure Verification Results

- Section 5.0 - Conclusions and Recommendations

- Section 6.0 - References

- Appendix A - Data Quality Objectives for CAU 396

- Appendix B - Closure Certification

- Appendix C - As Built Documentation

- Appendix D - Sample Analytical Results

- Appendix E - Waste Disposition Documentation

- Appendix F - Modifications

- Appendix G - Photographs of Closure Activities

- Library Distribution List

The following Appendices listed in the FFACO Closure Report outline do not apply to the CAU 396 closure:

- Appendix B - Closure Certification (Not applicable).

- Appendix C - As-Built Documentation (Not applicable, no engineered structures were constructed).

- Appendix F - Modifications to the Post-Closure Plan (Not applicable, no Post-Closure Plan is required for a site that is clean closed).

This report was developed using information and guidance from the following documents:

- Corrective Action Unit 396 Preliminary Assessment Information: Area 20 Spill Sites. Nevada Test Site, Nevada, (IT, 2001).

- $\quad$ Streamlined Approach For Environmental Restoration Plan for Corrective Action Unit 396: Area 20 Spill Sites. Nevada Test Site, Nevada, (NNSA/NSO, 2003).

- Nevada Environmental Restoration Project, Industrial Sites Quality Assurance Project Plan, Nevada Test Site, Nevada, Revision 3 (NNSA/NV, 2002) 


\subsubsection{Data Quality Objectives}

The data quality objectives (DQOs) used for closure of CAU 396 were presented in Appendix A1 of the CAU 396 SAFER Plan (NNSA/NSO, 2003), and are included in Appendix A of this report.

The general conceptual model as presented in the SAFER Plan (NNSA/NSO, 2003) was applied to all the CASs in CAU 396 and assumed that any surface contamination was the result of surface releases. The extent of the potential contamination was dependent on such variables as release volume, system design, geologic conditions, and nature of contamination.

CAU 396 closure activities determined that actual site conditions were in agreement with the conceptual model. Details of the DQO assessment are included in Section 4.1 of this report. 


\subsection{CLOSURE ACTIVITIES}

This section details the specific closure activities completed at CAU 396: Area 20 Spill Sites. Copies of the analytical data reports for all verification samples are included in Appendix D.

\subsection{DESCRIPTION OF CORRECTIVE ACTION ACTIVITIES}

\subsubsection{Preplanning and Site Preparation}

Closure activities for CAU 396 were completed using the NDEP-approved SAFER Plan for CAU 396 (NNSA/NSO, 2003). Prior to beginning closure activities, the following pre-field activities were completed:

- Preparation of a National Environmental Policy Act documentation (checklist).

- Preparation of a Field Management Plan.

- Preparation of a Site-Specific Health and Safety Plan.

- Preparation of a Real Estate/Operations Permit.

- Preparation of a Bechtel Nevada (BN) Work Permits.

- Performing a utility and radiological survey prior to beginning excavation activities.

\subsubsection{Summary of CAU 396 Site History}

The site history for CAU 396 is provided in the SAFER Plan (NNSA/NSO, 2003). The site history is briefly summarized below.

CAS 20-25-01, Oil Spills (2): Historical information for this CAS is limited. It is believed that these oil spills are associated with drilling operations at the U-20bc post-test cellar, which was drilled between November 6, 1989 and November 7, 1989 (Raytheon Services Nevada [RSN], 1991).

CAS 20-25-02, Oil Spills: Historical information for this CAS is limited. The oil spills are believed to be associated with drilling operations at the U-20ax emplacement hole between June 19, 1987 and August 18, 1987 (RSN, 1991). During the site visit on August 1, 2001, it was determined that the spills may have been backfilled and covered with pea-size gravel.

CAS 20-25-03, Oil Spill: Historical information for this CAS is limited. These oil spills are believed to be associated with drilling operations at the U-20az post-test hole between December 14, 1990 and December 16, 1990 (RSN, 1991).

CAS 20-99-08, Spill: Historical information for this CAS is limited. This spill is believed to be associated with drilling operations of the U-20bc between April 5, 1988 and June 28, 1988, or from the U-20bc post-test hole between November 5, 1989 and November 6, 1989 (RSN, 1991). During a site visit on August 28, 1997, it was noted that the spill is surrounded on three sides by a large bermed area. 


\subsubsection{Summary of CAU 396 Site Characterization Activities and Results}

The CAU 396 site characterization was completed in December 2001 and the results reported in the SAFER Plan (NNSA/NSO, 2003). At each of the four CASs, soil samples were collected using either a direct-push (Geoprobe ${ }^{\circledR}$ ) method or hand sampling, and were submitted to an offsite laboratory for analysis. Site characterization results are briefly summarized below.

CAS 20-25-01, Oil Spills (2): Soil samples were analyzed for volatile organic compounds (VOCs), semi volatile organic compounds (SVOCs), total Resource Conservation and Recovery Act (RCRA) metals, total petroleum hydrocarbons (TPH), gamma spectroscopy and polychlorinated biphenyls (PCBs). TPH was the only COC found to be present at concentrations greater than action levels (NAC, 2002). The SAFER Plan (NNSA/NSO, 2003) provides the results of this CAS characterization investigation.

CAS 20-25-02, Oil Spills: Soil samples were analyzed for VOCs, SVOCs, total RCRA metals, $\mathrm{TPH}$, gamma spectroscopy and PCBs. TPH was the only COC found to be present above the laboratory detection limit but was not greater than the action level (NAC, 2002). The SAFER Plan (NNSA/NSO, 2003) provides the results of this CAS characterization investigation.

CAS 20-25-03, Oil Spill: Soil samples were analyzed for VOCs, SVOCs, total RCRA metals, $\mathrm{TPH}$, gamma spectroscopy and PCBs. TPH was the only COC found to be present at concentrations greater than action levels (NAC, 2002). The SAFER Plan (NNSA/NSO, 2003) provides the results of this CAS characterization investigation.

CAS 20-99-08, Spill: At this site, a preliminary site assessment was conducted in August 1997. Sample ERS00178 was collected and analyzed for PCBs, SVOCs, RCRA metals, and radionuclides. PCB results for ERS00178 were 99 micrograms per kilogram. These results were incorrectly reported in the CAU 396 SAFER Plan as $99 \mathrm{mg} / \mathrm{kg}$ (NNSA/NSO, 2003). As a result, seven additional waste characterization samples were collected from the site in August 2003, and analyzed for PCBs, and RCRA metals. These results established that PCBs were not present at concentrations above action levels (EPA, 2001); no COCs were found to be present at concentration above action levels at this site. As a result, this site was closed by taking no further action. A copy of the PCB results for sample ERS00178 and the seven samples collected in August 2003 (sample numbers 20-99-08-1 through 20-99-08-7) are included in Appendix D.

\subsubsection{CAS 20-25-01, Oil Spills (2) Closure Activities}

CAS 20-25-01, Oil Spills (2), was clean closed by removing and disposing of approximately 16 cubic meters $\left(\mathrm{m}^{3}\right)$ (21 cubic yards $\left.\left[\mathrm{yd}^{3}\right]\right)$ of TPH-impacted soil. Closure activities began on March 16, 2004, and were completed on April 15, 2004. Two excavations were made at CAS 20-25-01, Using a front-end loader both measured approximately 3.6 meters $(\mathrm{m})$ (12 feet

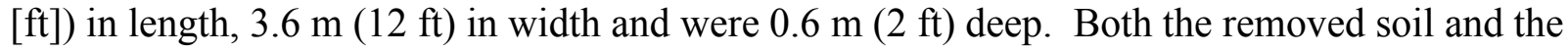
excavations were examined visually for staining or discoloration due to the presence of hydrocarbons. Excavation activities were guided by field screening with PetroFLAG ${ }^{\circledR}$ hydrocarbon field screening test kits. Initially, five verification samples were collected from each excavation. Verification samples results for excavation \#2 were all below the action levels. At excavation \#1, results for 2 verification samples were slightly higher than the TPH action level. For this reason, an additional $0.3 \mathrm{~m}(1 \mathrm{ft})$ of soil was removed from the north sidewall and 
from the bottom of excavation \#1 and two additional verification samples were collected. Results for the additional verification samples showed TPH concentrations were less than the action level.

All TPH-impacted soil removed was loaded into end-dumps and transported to the Area 6 Hydrocarbon Landfill for disposal. The excavation was backfilled with NTS native fill on April 15,2004 , compacted by wheel rolling with the front-end loader, and graded to the original site contours. All remaining fencing and debris were removed from the site.

\subsubsection{CAS 20-25-02, Oil Spills Closure Activities}

CAS 20-25-02, Oil Spills, was clean closed by removing and disposing of approximately $0.03 \mathrm{~m}^{3}$ $\left(0.04 \mathrm{yd}^{3}\right)$ of TPH-impacted soil. Excavation activities began and were completed on

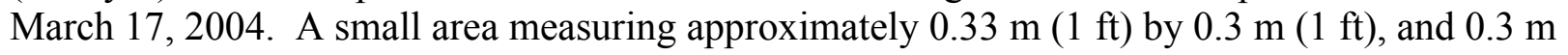
( $1 \mathrm{ft}$ ) deep was excavated by hand using a shovel. All removed TPH-impacted soil was placed into a 5-gallon bucket and transported to the Area 6 Hydrocarbon Landfill for disposal. The TPH-impacted soil was removed from this CAS as a best management practice (BMP).

Both the removed soil and the excavations were examined visually for staining or discoloration due to the presence of hydrocarbons. Once the excavations reached $0.3 \mathrm{~m}(1 \mathrm{ft})$ in depth, fieldscreening samples were collected from the bottom and sidewalls of each excavation. Each field screening sample was analyzed for TPH using a PetroFLAG ${ }^{\circledR}$ hydrocarbon field screening test kit. The TPH concentration decreased with increasing depth, and once TPH field-screening sample results were less than 75 parts per million, excavation activities ceased and soil verification samples were collected. Analytical results for the verification samples are discussed in Section 4.0.

\subsubsection{CAS 20-25-03, Oil Spill Closure Activities}

CAS 20-25-03, Oil Spill, was clean closed by removing and disposing of approximately $55.2 \mathrm{~m}^{3}$ $\left(72.6 \mathrm{yd}^{3}\right)$ of TPH-impacted soil. Excavation activities began on March 17, 2004, and were completed on April 19, 2004. Two areas were excavated at this CAS. Using a front-end loader

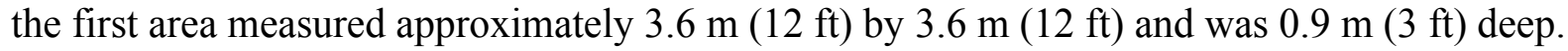

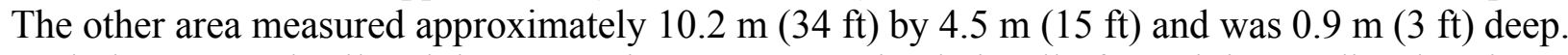
Both the removed soil and the excavations were examined visually for staining or discoloration due to the presence of hydrocarbons. Excavation activities were guided by field screening with PetroFLAG hydrocarbon field screening test kits. Initially, nine verification samples were collected from excavation \#1 (E1), and sixteen verification samples were collected from excavation \#2 (E2) including 1 blind duplicate sample. Verification sample results for two samples, one from each excavation (20-25-03 E1 V9 and 20-25-03 E2 V5), had TPH concentrations above the action level. For this reason, additional material was removed from both excavations. At E1 a hoe ram was used to break up the bottom of the excavation, and approximately 25.4 centimeters (10 inches) of weathered bedrock was removed. At E2 an additional $0.3 \mathrm{~m}(1 \mathrm{ft})$ of soil was removed from the western sidewall. Two additional verification samples were collected from the expanded excavations and submitted for TPH analysis to an off-site laboratory. Results for the additional verification samples showed TPH concentration were less than the action level. 
All removed TPH-impacted soil was loaded into end-dumps and transported to the Area 6 Hydrocarbon Landfill for disposal. The excavations were backfilled with NTS native fill on April 19, 2004, compacted by wheel rolling with the front-end loader, and graded to the original site contours. All remaining fencing and debris were removed from the site.

\subsubsection{CAS 20-99-08, Spill Closure Activities}

At CAS 20-99-08 no COC at concentrations above action levels were identified (NNSA/NSO, 2003), and no further action was taken.

\subsection{Deviations From SAFER Plan as APProved}

There were no deviations from the approved scope of work as outlined in the CAU 396 SAFER Plan (NNSA/NSO, 2003).

\subsection{Corrective ACTION SCHEdule AS COMPLETED}

The corrective action field activities began on March 10, 2004, and were completed on April 19, 2004. A corrective action schedule as completed is provided in Table 1.

\subsection{Site Plan/Survey Plat}

Because this is a clean closure, survey data are not required for this CR. Because engineered construction was not required as part of this closure, as-built drawings are not included in this CR. 


\section{TABLE 1 - CORRECTIVE ACTION SCHEDULE AS COMPLETED}

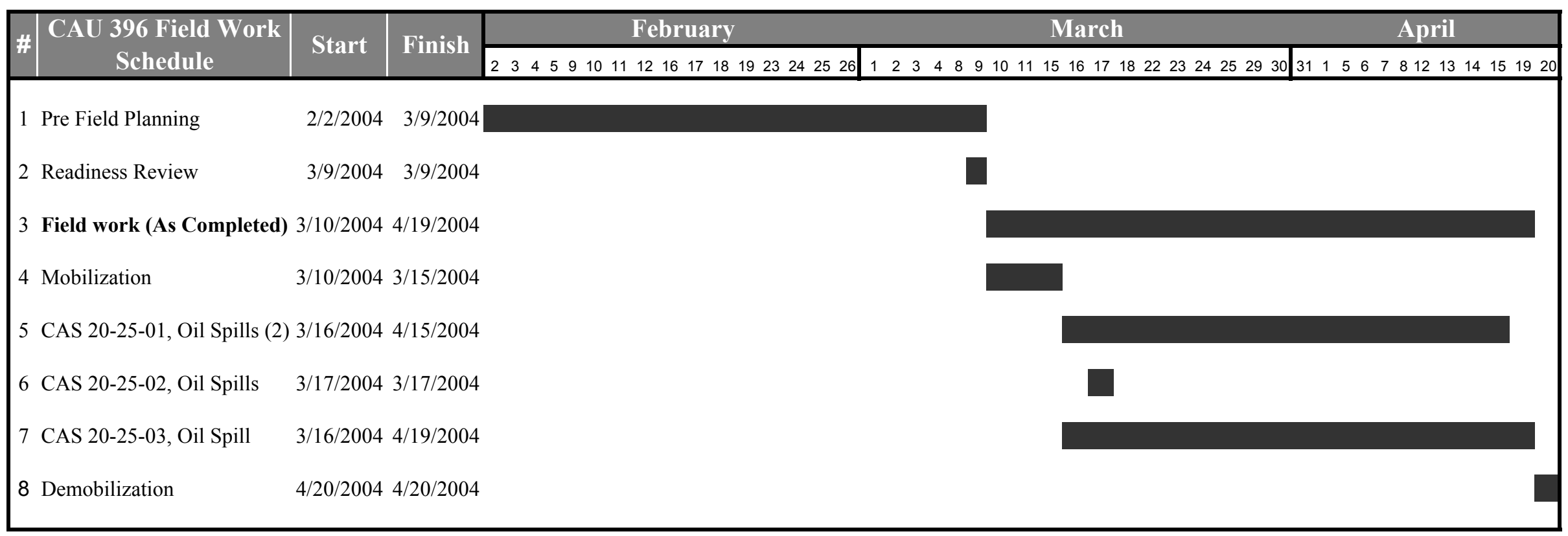


CLOSURE REPORT - CAU 396

Section: Closure Activities

Revision: 0

Date: June 2004

THIS PAGE LEFT INTENTIONALLY BLANK 


\subsection{WASTE DISPOSITION}

Wastes generated during the closure of CAU 396 consisted of TPH-impacted soil and sanitary waste. All TPH-impacted soil generated during the closure of CAU 396 was transported to the NTS Area 6 Hydrocarbon Landfill. Approximately 77,511 kilograms (173,024 pounds) of TPHimpacted soil from CAU 396 were transported and disposed of in the NTS Area 6 Hydrocarbon Landfill. All sanitary waste was disposed in the NTS Sanitary Landfill. Table 2 provides the dates and weights of TPH-impacted soil transported to the Area 6 hydrocarbon landfill for disposal. Copies from the Waste Management System database and copies of the NTS Onsite Load Verification Forms are provided in Appendix E.

TABLE 2: TPH WASTE QUANTITIES GENERATED DURING CLOSURE OF CAU 396

\begin{tabular}{|c|c|c|}
\hline DATE & KILOGRAMS & POUNDS \\
\hline $3 / 16 / 2004$ & 1590.9 & 3,500 \\
\hline $3 / 17 / 2004$ & 17390.9 & 38,260 \\
\hline $3 / 18 / 2004$ & 18800.9 & 41,362 \\
\hline $3 / 22 / 2004$ & 20650.9 & 45,432 \\
\hline $3 / 23 / 2004$ & 16804.6 & 36,970 \\
\hline $4 / 15 / 2004$ & 2272.7 & 5,000 \\
\hline $4 / 19 / 2004$ & 1136.4 & 2,500 \\
\hline Total & $\mathbf{7 8 , 6 4 7 . 3}$ & $\mathbf{1 7 3 , 0 2 4}$ \\
\hline
\end{tabular}


CLOSURE REPORT - CAU 396

Section: Waste Disposition

Revision: 0

Date: June 2004

THIS PAGE LEFT INTENTIONALLY BLANK 


\subsection{CLOSURE VERIFICATION RESULTS}

Site closure was verified by collecting soil verification samples from each excavated area within CAS 20-25-01, CAS 20-25-02, and CAS 20-25-03. The following number of verification samples as specified in the SAFER Plan (NNSA/NSO, 2003) were collected from the indicated sites verifying that the sites have been clean closed:

- CAS 20-25-01

- CAS 20-25-02

- CAS 20-25-03

- CAS 20-99-08
12 verification samples (including two resamples)

3 verification samples (including one blind duplicate)

23 verification samples (including one blind duplicate and two resamples)

0 verification samples

All verification samples were collected with decontaminated disposable scoops, placed in appropriately labeled sample containers, and secured with custody seals. All samples were labeled with a unique sample number, placed on ice in coolers, and transported under chain-ofcustody to the BN Analytical Services Group for shipment to an off-site laboratory. All samples were analyzed for TPH full scan.

CAS 20-25-01, Oil Spills (2), At this site TPH-impacted soil was removed from two locations. Originally ten soil verification samples were collected on March 18, 2004, five from excavation \#1 (E1), and five from excavation \#2 (E2). Four samples were collected from the sidewalls and one from the bottom of E1 and E2 respectfully, and submitted to an off-site laboratory for TPH analysis (Figure 2). Analytical results for all samples from E2 and for three of the samples from E1 were less than the TPH action level. Analytical results for two samples collected from the north sidewall and the bottom of E1 were greater than the TPH action level. For this reason, an additional $0.3 \mathrm{~m}(1 \mathrm{ft})$ of soil was removed from the north sidewall and $0.15 \mathrm{~m}(0.5 \mathrm{ft})$ from the bottom of E1. Two additional verifications samples were collected on April 7, 2004, from the north sidewall and from the bottom of the expanded E1, and submitted to an off-site laboratory for TPH analysis. Analytical results for these additional verification samples were less than the TPH action level; verifying that TPH-impacted soil in excess of the action level was removed from the site. Verification sample results are summarized in Table 3 and analytical data are included in Appendix D.

CAS 20-25-02, Oil Spills. Three soil verification samples (including one blind duplicate) were collected from the sidewall and the bottom of the excavation and submitted to an off-site laboratory for TPH analysis (Figure 3). Analytical results for the verification samples show that TPH-impacted soil in excess of the action level was removed. Verification samples results are summarized in Table 3, and analytical data is included in Appendix D.

CAS 20-25-03, Oil Spill. At this site, TPH-impacted soil was removed from two locations. Originally 23 soil verification samples (including one duplicate) were collected from the sidewalls and the bottom of the two excavations, E1 and E2. Nine samples were collected from E1, and 14 samples were collected from E2 on March 22 and 23, 2004 respectively and submitted to an off-site laboratory for TPH analysis (Figure 4). Analytical results for all samples 


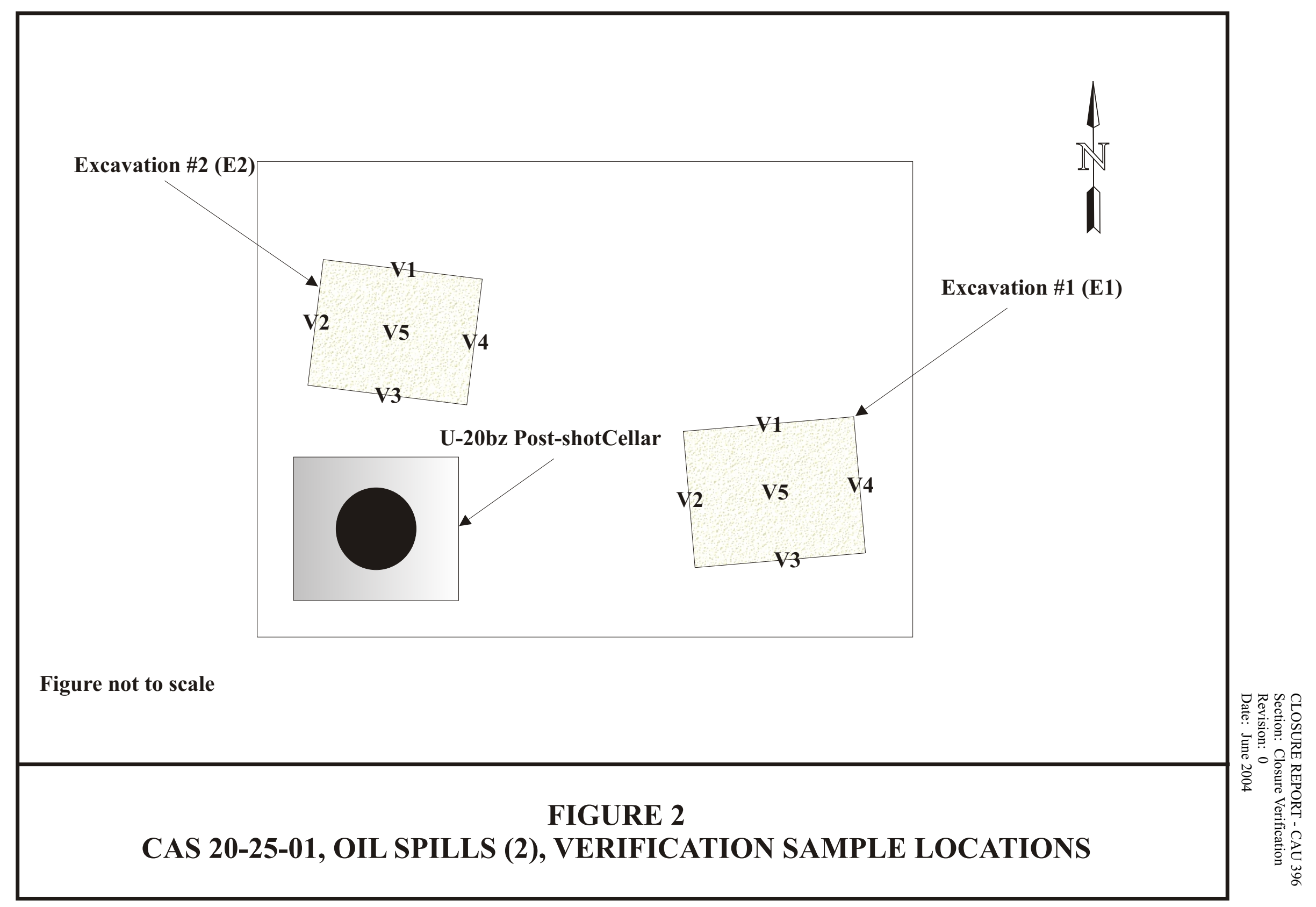




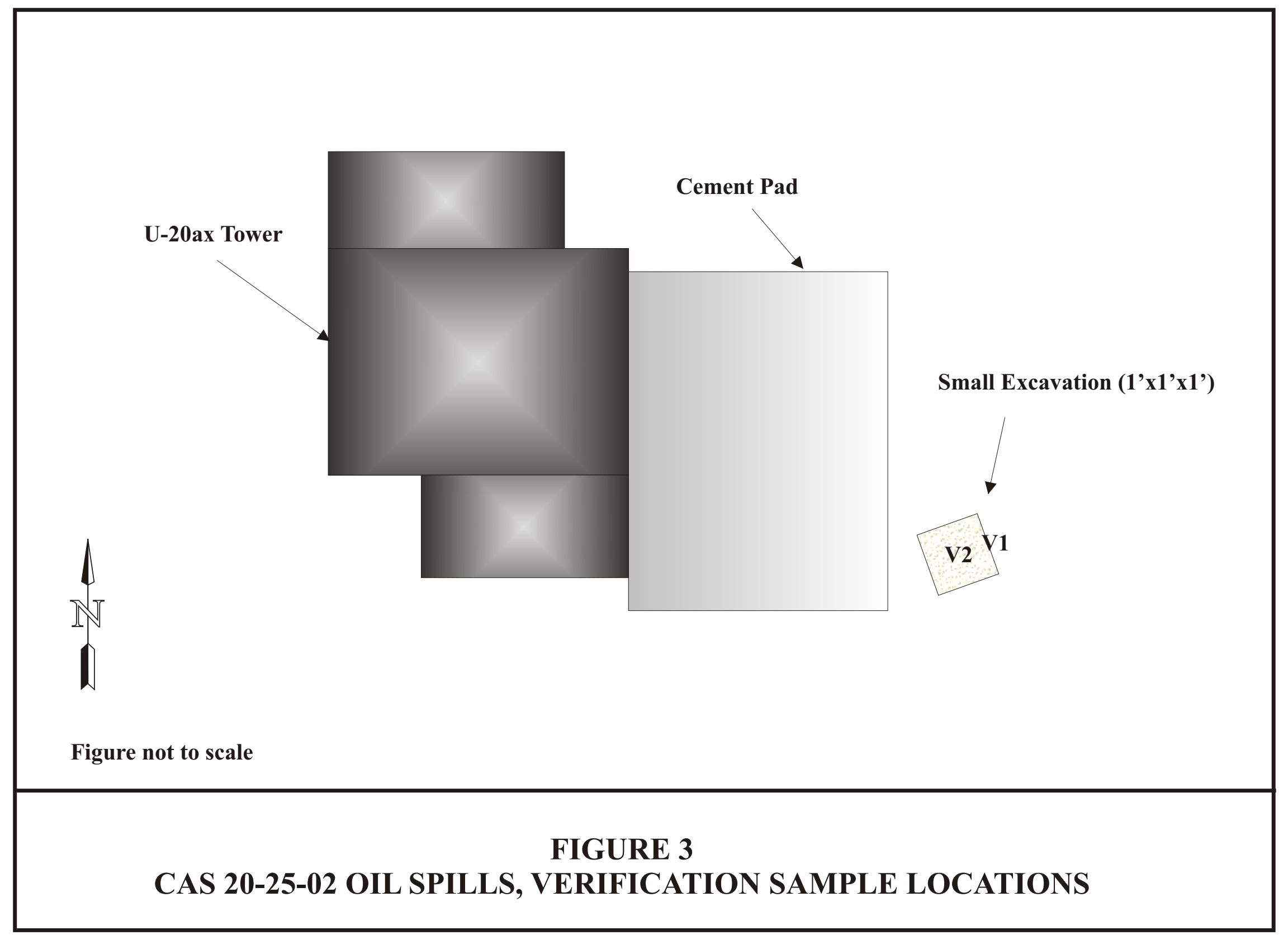




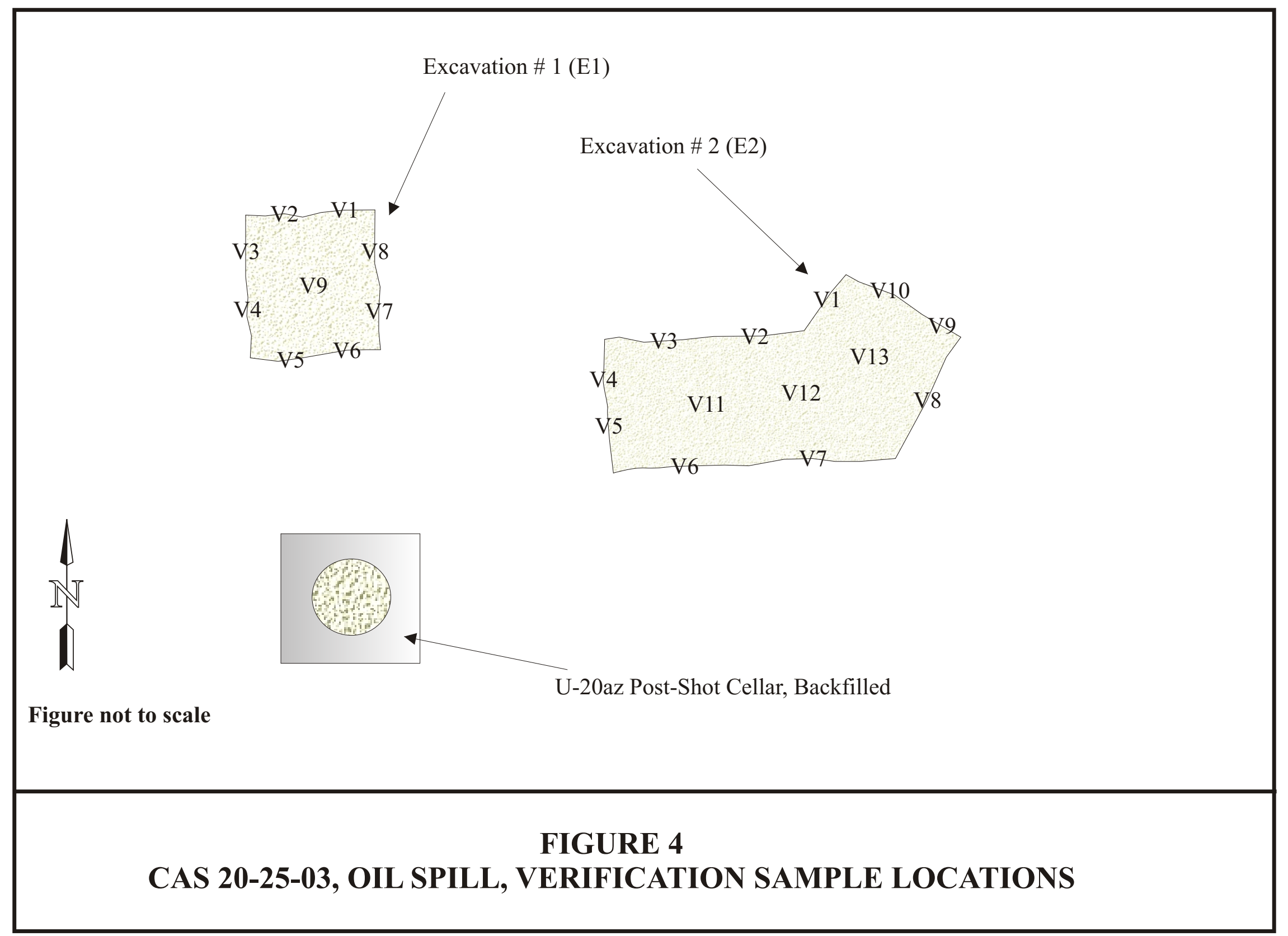




\section{TABLE 3: CAU 396 VERIFICATION SAMPLE RESULTS}

\begin{tabular}{|c|c|c|c|c|c|c|}
\hline $\begin{array}{l}\text { SAMPLE } \\
\text { NUMBER }\end{array}$ & $\begin{array}{c}\text { Date } \\
\text { COLLECTED }\end{array}$ & $\begin{array}{c}\text { DEPTH } \\
\left(\text { FEET BGS }^{A}\right)\end{array}$ & $\begin{array}{l}\text { DIESEL } \\
\text { RANGE }^{\text {B }} \\
(\mathrm{mg} / \mathbf{k g})^{\mathrm{C}}\end{array}$ & $\begin{array}{l}\text { GASOLINE } \\
\text { RANGE }^{\mathrm{B}} \\
\text { (mg/kg) }^{\mathrm{C}}\end{array}$ & $\mid \begin{array}{c}\text { OIL RANGE }^{\mathrm{B}} \\
(\mathrm{mg} / \mathrm{kg})^{\mathrm{C}}\end{array}$ & $\begin{array}{c}\text { TOTAL } \\
\text { PETROLEUM } \\
\text { HYDROCARBONs } \\
(\mathrm{mg} / \mathrm{kg})^{\mathrm{C}} \\
\end{array}$ \\
\hline \multicolumn{3}{|l|}{ Action Level $^{\mathrm{D}}$} & 100 & 100 & 100 & 100 \\
\hline \multicolumn{7}{|c|}{ CAS 20-25-01, Oil Spills (2) - SDG ${ }^{\mathrm{E}}$ V2232 and V2243 } \\
\hline 20-25-01 E1 V1 & $03 / 18 / 2004$ & 1 & ND & ND & 110 & 110 \\
\hline 20-25-01 E1 V2 & $03 / 18 / 2004$ & 1 & ND & ND & ND & ND \\
\hline 20-25-01 E1 V3 & 03/18/2004 & 1 & ND & ND & ND & ND \\
\hline 20-25-01 E1 V4 & $03 / 18 / 2004$ & 1 & ND & ND & ND & ND \\
\hline 20-25-01 E1 V5 & 03/18/2004 & 1.5 & ND & ND & 110 & 110 \\
\hline 20-25-01 E2 V1 & $03 / 18 / 2004$ & 1 & ND & ND & ND & ND \\
\hline 20-25-01 E2 V2 & 03/18/2004 & 1 & ND & ND & ND & ND \\
\hline 20-25-01 E2 V3 & 03/18/2004 & 1 & ND & ND & ND & ND \\
\hline 20-25-01 E2 V4 & $03 / 18 / 2004$ & 1 & ND & ND & ND & ND \\
\hline 20-25-01 E2 V5 & $03 / 18 / 2004$ & 1.5 & ND & ND & ND & ND \\
\hline $\begin{array}{c}\text { 20-25-01 E1 V1 } \\
\text { (resample of E1 V1) }\end{array}$ & $04 / 07 / 2004$ & 1 & ND & ND & ND & ND \\
\hline $\begin{array}{c}20-25-01 \text { E1 V5 } \\
(\text { resample of E1 V5) }\end{array}$ & $04 / 07 / 2004$ & 2 & ND & ND & ND & ND \\
\hline \multicolumn{7}{|c|}{ CAS 20-25-02, Oil Spills - SDG ${ }^{\mathrm{E}}$ V2232 } \\
\hline $20-25-02 \mathrm{~V} 1$ & $03 / 22 / 2004$ & 0.5 & ND & ND & ND & ND \\
\hline $20-25-02 \mathrm{~V} 2$ & $03 / 22 / 2004$ & 1 & ND & ND & ND & ND \\
\hline $\begin{array}{c}\text { 20-25-02 V3 } \\
\text { (duplicate of V2) }\end{array}$ & $03 / 22 / 2004$ & 1 & ND & ND & ND & ND \\
\hline \multicolumn{7}{|c|}{ CAS 20-25-03, Oil Spill - SDG ${ }^{\mathrm{E}}$ V2232 and V2243 } \\
\hline 20-25-03 E1 V1 & $03 / 22 / 2004$ & 3 & ND & ND & ND & ND \\
\hline 20-25-03 E1 V2 & $03 / 22 / 2004$ & 3 & $\mathrm{ND}$ & ND & ND & ND \\
\hline 20-25-03 E1 V3 & $03 / 22 / 2004$ & 3 & $\mathrm{ND}$ & ND & ND & ND \\
\hline 20-25-03 E1 V4 & $03 / 22 / 2004$ & 3 & ND & ND & ND & ND \\
\hline 20-25-03 E1 V5 & $03 / 22 / 2004$ & 3 & $\mathrm{ND}$ & ND & ND & ND \\
\hline 20-25-03 E1 V6 & 03/22/2004 & 3 & $\mathrm{ND}$ & ND & ND & ND \\
\hline 20-25-03 E1 V7 & $03 / 22 / 2004$ & 3 & $\mathrm{ND}$ & ND & ND & ND \\
\hline 20-25-03 E1 V8 & 03/22/2004 & 3 & ND & ND & ND & ND \\
\hline 20-25-03 E1 V9 & $03 / 22 / 2004$ & 3 & 130 & ND & 2400 & 2500 \\
\hline \begin{tabular}{|c|} 
20-25-03 E1 V9 \\
(resample of E1 V9)
\end{tabular} & 04/07/2004 & 3.5 & ND & ND & ND & ND \\
\hline
\end{tabular}

${ }^{\mathrm{A}}$ bgs $=$ below ground surface

B Total Petroleum Hydrocarbons full scan analysis by EPA method 8015 modified (EPA, 1996).

${ }^{\mathrm{C}} \mathrm{mg} / \mathrm{kg}=$ milligrams per kilogram

D Total Petroleum Hydrocarbon action level of $100 \mathrm{mg} / \mathrm{kg}$ established by the State of Nevada (NAC, 2002).

${ }^{\mathrm{E}} \mathrm{SDG}$ - Sample Delivery Group. Used to identify a group of samples submitted for analysis.

$\mathrm{ND}=$ Not detected above the laboratory minimum reporting limit. 


\section{TABLE 3: CAU 396 VeRIFICATION SAMPLE RESUlts (continued)}

\begin{tabular}{|c|c|c|c|c|c|c|}
\hline $\begin{array}{l}\text { SAMPLE } \\
\text { NUMBER }\end{array}$ & \begin{tabular}{|c|} 
DATE \\
COLLECTED
\end{tabular} & $\begin{array}{c}\text { DEPTH } \\
\left(\text { FEET BGS }^{A}\right)\end{array}$ & $\begin{array}{l}\text { DIESEL } \\
\text { RANGE }^{\mathrm{B}} \\
(\mathrm{mg} / \mathrm{kg})^{\mathrm{C}}\end{array}$ & $\begin{array}{l}\text { GASOLINE } \\
\text { RANGE }^{\text {B }} \\
(\mathrm{mg} / \mathbf{k g})^{\mathrm{C}}\end{array}$ & $\begin{array}{r}\text { OIL RANGE }{ }^{\text {B }}(\mathbf{m g} / \mathbf{k g})^{\mathrm{C}}\end{array}$ & $\begin{array}{c}\text { TOTAL } \\
\text { PETROLEUM } \\
\text { HYDROCARBONS } \\
(\mathrm{mg} / \mathrm{kg})^{\mathrm{C}}\end{array}$ \\
\hline \multicolumn{3}{|l|}{ Action Level $^{\mathrm{D}}$} & 100 & 100 & 100 & 100 \\
\hline \multicolumn{7}{|c|}{ CAS 20-25-03, Oil Spill - SDG ${ }^{\mathrm{E}}$ V2232 and V2243 } \\
\hline 20-25-03 E2 V1 & $03 / 23 / 2004$ & 3 & ND & ND & ND & ND \\
\hline 20-25-03 E2 V2 & $03 / 23 / 2004$ & 3 & ND & ND & ND & ND \\
\hline 20-25-03 E2 V3 & $03 / 23 / 2004$ & 2 & ND & ND & ND & ND \\
\hline 20-25-03 E2 V4 & $03 / 23 / 2004$ & 2 & ND & ND & ND & ND \\
\hline 20-25-03 E2 V5 & $03 / 23 / 2004$ & 2 & 300 & ND & 140 & 430 \\
\hline 20-25-03 E2 V6 & $03 / 23 / 2004$ & 2 & ND & ND & ND & $\mathrm{ND}$ \\
\hline 20-25-03 E2 V7 & $03 / 23 / 2004$ & 3 & ND & ND & ND & ND \\
\hline 20-25-03 E2 V8 & 03/23/2004 & 3 & ND & ND & ND & ND \\
\hline 20-25-03 E2 V9 & $03 / 23 / 2004$ & 3 & ND & ND & ND & ND \\
\hline 20-25-03 E2 V10 & $03 / 23 / 2004$ & 3 & ND & ND & ND & ND \\
\hline 20-25-03 E2 V11 & 03/23/2004 & 2 & ND & ND & ND & ND \\
\hline 20-25-03 E2 V12 & $03 / 23 / 2004$ & 3.5 & ND & ND & ND & ND \\
\hline 20-25-03 E2 V13 & $03 / 23 / 2004$ & 3.5 & ND & ND & ND & ND \\
\hline $\mid \begin{array}{c}20-25-03 \text { E2 V14 } \\
\text { (duplicate of E2 V12) }\end{array}$ & $03 / 22 / 2004$ & 3.5 & ND & ND & ND & ND \\
\hline $\begin{array}{c}\text { 20-25-03 E2 V5 } \\
\text { (resample of E2 V5) }\end{array}$ & 04/07/2004 & 2.5 & ND & ND & ND & ND \\
\hline
\end{tabular}

${ }^{\mathrm{A}}$ bgs $=$ below ground surface

B Total Petroleum Hydrocarbons full scan analysis by EPA method 8015 modified (EPA, 1996).

${ }^{\mathrm{C}} \mathrm{mg} / \mathrm{kg}=$ milligrams per kilogram

D Total Petroleum Hydrocarbon action level of $100 \mathrm{mg} / \mathrm{kg}$ established by the State of Nevada (NAC, 2002).

${ }^{\text {E }}$ SDG - Sample Delivery Group. Used to identify a group of samples submitted for analysis.

$\mathrm{ND}=$ Not detected above the laboratory minimum reporting limit.

except two were less than the TPH action level. The samples collected from the bottom of E1 at location V9 and from the western sidewall of E2 at location V5 exceeded the TPH action level. For this reason additional material was removed from both excavations. At E1 approximately $0.15 \mathrm{~m}(0.5 \mathrm{ft})$ of weathered bedrock was removed from the excavation bottom, and at E2 approximately $0.3 \mathrm{~m}(1 \mathrm{ft})$ of additional soil was removed from the western sidewall. Additional verification samples were collected form the center of the expanded E1 and the western sidewall of the expanded E2 on April 7, 2004 and submitted to an off-site laboratory for analysis. Analytical results for these additional verification samples were less than the TPH action level; verifying that TPH-impacted soil in excess of the action level was removed from the site. Verification samples results are summarized in Table 3 and analytical data is included in Appendix D.

CAS 20-99-08, Spill. As discussed in Section 2.1.3, no further action was taken since no COCs above action levels were found at this site. 


\subsection{Data Quality Assessment}

CAU 396 closure activities were performed to the criteria specified in the NDEP-approved SAFER Plan (NNSA/NSO, 2003). The approved corrective action alternatives as implemented did not result in any deviation with the conceptual model as presented in the SAFER Plan (NNSA/NSO, 2003) and included in Appendix A of this report.

All verification samples were analyzed for TPH by off-site contract laboratories. All quality assurance/quality control samples required by the BN analytical laboratories' contracts were prepared and analyzed. In addition, duplicate samples were collected in the field and sent to the laboratory with unique sample numbers. Table 3 gives the results for all collected verification samples.

CAS 20-25-01, Oil Spills (2). As detailed in the CAU 396 SAFER plan, the primary conceptual site model (CSM) for this site assumes that TPH is the only COC present and that it was released to the ground surface. The dimensions of the two spill sites were originally estimated from analytical results for one waste characterization sample collected during site preliminary assessment performed in 1997 (NNSA/NSO, 2003). Based on the site preliminary assessment (PA) results, the spill sites were estimated to measure approximately 10.8 by $21.6 \mathrm{~m}$ (36 by $72 \mathrm{ft}$ ) and 6 by $6 \mathrm{~m}$ ( 20 by $20 \mathrm{ft})$. To better define the lateral and vertical extent of the spill sites, additional waste characterization samples were collected using direct push techniques in August 2003. Based on results for these additional samples, the approximate size of both spill sites were reduced to 3.6 by 3.6 by $0.6 \mathrm{~m}$ (12 by 12 by $2 \mathrm{ft}$ ), and the only COC detected was TPH. Observations made during closure activities indicate that the spill site excavations approximated these dimensions. Based on these results and on field observations, the actual site conditions agreed with the primary CSM as stated in the SAFER Plan (NNSA/NSO, 2003).

CAS 20-25-02, Oil Spills. As detailed in the CAU 396 SAFER plan, the primary CSM for this site assumes that TPH is the only COC present and that it was released to the ground surface. The dimensions of the spill site was originally estimated from analytical results for one waste characterization sample collected during site preliminary assessment performed in 1997 (NNSA/NSO, 2003). Based on the PA results, the spill site was estimated to measure approximately 18 by $22.8 \mathrm{~m}$ (60 by $76 \mathrm{ft}$ ). To better define the lateral and vertical extent of the spill sites, additional waste characterization samples were collected using direct push techniques in August 2003. Based on results for these additional samples, the approximate size of the spill site was reduced to by 0.3 by 0.3 by $0.3 \mathrm{~m}$ ( 1 by 1 by $1 \mathrm{ft}$ ), and the only COC detected was TPH. Observations made during closure activities indicate the spill site excavations approximated these dimensions. Based on these results and on field observations, the actual site conditions agreed with the primary CSM as stated in the SAFER Plan (NNSA/NSO, 2003).

CAS 20-25-03, Oil Spill. As detailed in the CAU 396 SAFER plan, the primary CSM for this site assumes that TPH is the only COC present and that it was released to the ground surface. The dimensions of the two spill sites were originally estimated from analytical results for four waste characterization samples collected during site preliminary assessment performed in 1997 (NNSA/NSO, 2003). Based on the PA results, the spill site was estimated to measure approximately 15 by $15 \mathrm{~m}$ (50 by $50 \mathrm{ft}$ ). To better define the lateral and vertical extent of the spill sites, additional waste characterization samples were collected using direct push techniques in August of 2003. Based on results for these additional samples it was determined that there 
were two areas with TPH-impacted soil above the action level. The approximate sizes of both spill sites were determined to be 3.6 by 3.6 by $0.9 \mathrm{~m}$ ( 12 by 12 by $3 \mathrm{ft}$ ) and 10.2 by 4.5 by $0.9 \mathrm{~m}$ (34 by 15 by $3 \mathrm{ft}$ ), and the only COC detected was TPH. Observations made during closure activities indicate that the spill site excavations approximated these dimensions. Based on these results and on field observations, the actual site conditions agreed with the primary CSM as stated in the SAFER Plan (NNSA/NSO, 2003).

CAS 20-99-08, Spill. As detailed in the CAU 396 SAFER plan, the primary CSM for this site assumes that PCBs are the only COC present and that it was released to the ground surface. The dimensions of the spill site were originally estimated from analytical results for one waste characterization sample collected during site preliminary assessment performed in 1997 (NNSA/NSO, 2003). Based on the PA results, the spill site was estimated to measure approximately 37.5 by $37.5 \mathrm{~m}$ (125 by $125 \mathrm{ft}$ ). To better define the lateral and vertical extent of the spill site, additional waste characterization samples were collected using direct push techniques in August 2003. Based on results for these additional samples, the approximate size of the spill site was reduced to 0.3 by 0.3 by $0.3 \mathrm{~m}$ ( 1 by 1 by $1 \mathrm{ft}$ ). The only COC detected was PCBs at concentrations less than action levels, therefore no further action was taken. Based on these results and on field observations, the actual site conditions did not agree with the primary CSM as stated in the SAFER Plan (NNSA/NSO, 2003).

\subsection{USE RESTRICTION}

Since the corrective actions at CAU 396 were clean closure or no further action, no land use restrictions or post-closure monitoring requirements are applicable. 


\subsection{CONCLUSIONS AND RECOMMENDATIONS}

\subsection{CONCLUSION}

The following site closure activities were completed at each site within CAU 396 and are documented in this report:

CAS 20-25-01, Oil Spills (2). TPH-impacted soil above the $100 \mathrm{mg} / \mathrm{kg}$ action level (NAC, 2002) was removed from the site and transported to the Area 6 Hydrocarbon Landfill for disposal. The site was backfilled with NTS native fill, compacted by wheel-rolling, and graded to the original site contours.

CAS 20-25-02, Oil Spills. TPH-impacted soil above the $100 \mathrm{mg} / \mathrm{kg}$ action level (NAC,2002) was removed from the site by hand using a shovel and transported to the Area 6 Hydrocarbon Landfill for disposal. The small excavation was backfilled with NTS native fill, manually compacted, and graded to the original site contours.

CAS 20-25-03, Oil Spill. TPH-impacted soil above the $100 \mathrm{mg} / \mathrm{kg}$ action level (NAC 2002) was removed from the site and transported to the Area 6 Hydrocarbon Landfill for disposal. The site was backfilled with NTS native fill, compacted by wheel-rolling, and graded to the original site contours.

CAS 20-99-08, Spill. No COCs were found above action levels at this site, so no further action was taken.

\subsection{RECOMMENDATIONS}

Closure activities for CAU 396 were completed following the approved SAFER Plan (NNSA/NSO, 2003). Based on completion of site closure activities as documented by this CR, it is requested that a notice of completion be provided by the NDEP for CAU 396 and that the CAU be promoted from Appendix III to Appendix IV of the FFACO (1996), "Closed Corrective Action Units." 
CLOSURE REPORT - CAU 396

Section: Conclusions \& Recommendations

Revision: 0

Date: June 2004

THIS PAGE INTENTIONALLY LEFT BLANK 


\subsection{REFERENCES}

BN, see Bechtel Nevada.

Bechtel Nevada. 2002. Field Management Plan for Corrective Action Unit 396: Area 20 Spill Sites, Nevada Test Site, Nevada, Las Vegas, NV.

Bechtel Nevada. 2002. Site-Specific Health and Safety Plan for Corrective Action Unit 396: Area 20 Spill Sites, Nevada Test Sites, Nevada, Las Vegas, NV.

EPA, see U.S. Environmental Protection Agency.

FFACO, see Federal Facility Agreement and Consent Order.

Federal Facility Agreement and Consent Order. 1996 (as amended). Agreed to by the State of Nevada, U.S. Department of Energy, and U.S. Department of Defense.

IT, see International Technology Corporation.

International Technology Corporation. 2001. CAU 396: Area 20 Spill Sites, NTS, Project Files, Las Vegas, NV.

NAC, see Nevada Administrative Code.

Nevada Administrative Code. 2002. Section 445A.2272, "Contamination of soil: Establishment of Action Levels." Carson City, NV.

Nevada Environmental Restoration Project. 2002. Industrial Sites Quality Assurance Project Plan, Nevada Test Site, Nevada, Revision 3 (NNSA/NV, 2002)

NNSA/NSO, see U.S. Department of Energy, National Nuclear Security Administrations, Nevada Site Office.

NNSA/NV, see U.S. Department of Energy, National Nuclear Security Administration Nevada Operations Office.

RSN, see Raytheon Services Nevada.

Raytheon Services Nevada. 1991. Nevada Test Site Drilling and Mining Summary. Prepared for the U.S. Department of Energy, Nevada Operations Office. Las Vegas, NV.

U.S. Environmental Protection Agency. 1996. Test Methods for Evaluating Solid Waste, Physical/Chemical Methods, EPA Publication SW-846, Third Edition, Washington D.C.

US Department of Energy, National Nuclear Security Administration, Nevada Site Office. 2003. Streamlined Approach for Environmental Restoration Plan for Corrective Action Unit 396: Area 20 Spill Sites, Nevada Test Sites, Nevada, DOE/NV--884, Las Vegas, NV. 
CLOSURE REPORT - CAU 396

Section: References

Revision: 0

Date: June 2004

THIS PAGE INTENTIONALLY LEFT BLANK 


\section{APPENDIX A}

\section{DATA QUALITY OBJECTIVES FOR CAU 396*}

* As presented (as Appendix A-1) in the approved Streamlined Approach For Environmental Restoration Plan for Corrective Action Unit 396: Area 20 Spill Sites, Nevada Test Site, Nevada, March 2003, DOE/NV--884, Rev. 0, Las Vegas, NV. 
CLOSURE REPORT - CAU 396

Section: Appendix A

Revision: 0

Date: June 2004

THIS PAGE INTENTIONALLY LEFT BLANK 


\section{ACRONYMS AND ABBREVIATIONS}

\begin{tabular}{|c|c|}
\hline $\mathrm{BN}$ & Bechtel Nevada \\
\hline CAS & Corrective Action Site \\
\hline CAU & Corrective Action Unit \\
\hline $\mathrm{cm}$ & centimeter(s) \\
\hline $\mathrm{cm} / \mathrm{y}$ & centimeter(s) per year \\
\hline $\mathrm{COC}$ & contaminant(s) of concern \\
\hline $\mathrm{COPC}$ & contaminant(s) of potential concern \\
\hline CSM & conceptual site model \\
\hline $\mathrm{DOE} / \mathrm{NV}$ & U.S. Department of Energy, Nevada Operations Office \\
\hline DQO & Data Quality Objective \\
\hline EPA & U.S. Environmental Protection Agency \\
\hline FFACO & Federal Facility Agreement and Consent Order \\
\hline $\mathrm{ft}$ & foot/feet \\
\hline GC & Gas Chromatograph \\
\hline in & $\operatorname{inch}(s)$ \\
\hline in $/ y$ & inch(s) per year \\
\hline IT & International Technology Corporation \\
\hline $\mathrm{km}$ & kilometer(s) \\
\hline $\mathrm{m}$ & meter(s) \\
\hline $\mathrm{mg} / \mathrm{kg}$ & milligram(s) per kilogram \\
\hline $\mathrm{mi}$ & mile(s) \\
\hline NAC & Nevada Administrative Code \\
\hline NDEP & Nevada Division of Environmental Protection \\
\hline NNSA/NSO & $\begin{array}{l}\text { U.S. Department of Energy, National Nuclear Security Administration Nevada } \\
\text { Site Office }\end{array}$ \\
\hline NNSA/NV & $\begin{array}{l}\text { U.S. Department of Energy, National Nuclear Security Administration Nevada } \\
\text { Operations Office }\end{array}$ \\
\hline NTS & Nevada Test Site \\
\hline PCB & polychlorinated biphenyls \\
\hline $\mathrm{pCi} / \mathrm{g}$ & picoCuries per gram \\
\hline PRG & Preliminary Remediation Goals \\
\hline RCRA & Resource Conservation and Recovery Act \\
\hline RPD & relative percent difference \\
\hline RSM & Radiological Safety Marker \\
\hline RSN & Raytheon Services Nevada \\
\hline SAFER & Streamlined Approach for Environmental Restoration \\
\hline SDG & Sample Delivery Group \\
\hline SVOC & Semivolatile organic compound \\
\hline $\mathrm{TPH}$ & total petroleum hydrocarbon \\
\hline VOC & volatile organic compound \\
\hline
\end{tabular}


SAFER Plan - CAU 396

Section: Appendix A1

Revision: 0

Date: March 2003

THIS PAGE INTENTIONALLY LEFT BLANK

A1-iv 


\section{DATA QUALITY OBJECTIVES FOR CORRECTIVE ACTION UNIT 396: AREA 20 SPILL SITES}

The information presented here is based on historical data generated from preliminary assessment activities for Corrective Action Unit (CAU) 396 at the Nevada Test Site (NTS). Data quality objective (DQO) worksheets follow the U.S. Environmental Protection Agency (EPA) DQO guidance outline (EPA, 2000). The steps systematically build on the data acquired during preliminary assessment work and background research. Copies of the preliminary assessment work are retained in the project files.

Members of the Scoping Team and Decision Teams are as follows:

1. Scoping Team

a. U.S. Department of Energy, National Nuclear Security Administration Nevada Site Office (NNSA/NSO)

Kevin Cabble

b. Nevada Division of Environmental Protection (NDEP)

Ted Zaferatos

c. Bechtel Nevada (BN)

Thomas Fitzmaurice

Kraig Knapp

David Nacht

Glenn Richardson

2. Core Decision Team

Kevin Cabble

Glenn Richardson

3. Primary Decision Makers

Kevin Cabble 


\subsection{PROBLEM STATEMENT}

\subsection{State the problem}

Four Corrective Action Sites (CASs) that comprise Corrective Action Unit (CAU) 396, have been identified for closure (Figure A1-1). In order to properly close these sites, current data and existing information will be evaluated and used to develop conceptual site models (CSMs). These data will also be used to develop closure altematives. CAU 396 consists of sites located in Area 20 of the Nevada Test Site (NTS), and is currently listed in Appendix III of the Federal Facility Agreement and Consent Order (FFACO, 1996). One of the corrective action sites (CAS) within CAU 396 was not identified during the initial site visit. Based upon the original site description, (Reynolds Electrical and Engineering Co., Inc., 1991) and a site visit on February 4, 2003, it was determined that this CAS is located in a "potential crater area" and poses a potential safety risk to personnel working at the site. Therefore, an FFACO modification request to remove this CAS from CAU 396 and place it in CAU 544 will be prepared and submitted. Pending the approval of this FFACO modification, CAU 396 will consist of the following four CASs:

\footnotetext{
- $\quad$ CAS 20-25-01, Oil Spills (2)

- $\quad$ CAS 20-25-02, Oil Spills

- $\quad$ CAS 20-25-03, Oil Spill

- $\quad$ CAS 20-99-08, Spill
}

Upon approval of the FFACO modification request the following CAS 20-25-05, Oil Spills which is currently in CAU 396 will be moved to CAU 544: Cellars, Mud Pits, and Oil Spills

\subsection{Summarize the problem - combine the relevant background information into a concise description of the problem to be resolved and known or suspected sources of disposed waste.}

There were 828 underground nuclear tests conducted at the NTS between November 1951 and September 1992 (U.S. Department of Energy, Nevada Operation Office [DOE/NV], 2000). Several different types of holes were drilled into the ground for each test. Holes were drilled for exploratory purposes, device emplacement, and placement of instrumentation prior to the test. Holes were drilled after the test to collect samples of the affected media. Regardless of the purpose of the borehole, drill rigs and other equipment may have released contaminants into the environment. The contaminants of potential concern (COPCs) can include total petroleum hydrocarbons (TPH), polychlorinated biphenyls (PCBs), volatile organic compounds (VOCs), semivolatile organic compounds (SVOCs), Resource Conservation and Recovery Act (RCRA) metals, and various radionuclides. The Mud Pit Strategy report provides the details on why these COPCs are possibly associated with drilling activities (DOE/NV, 2001). The problem that needs to be resolved is whether the spills identified in CAU 396 pose a significant risk to human health or the environment. 
Date: March 2003

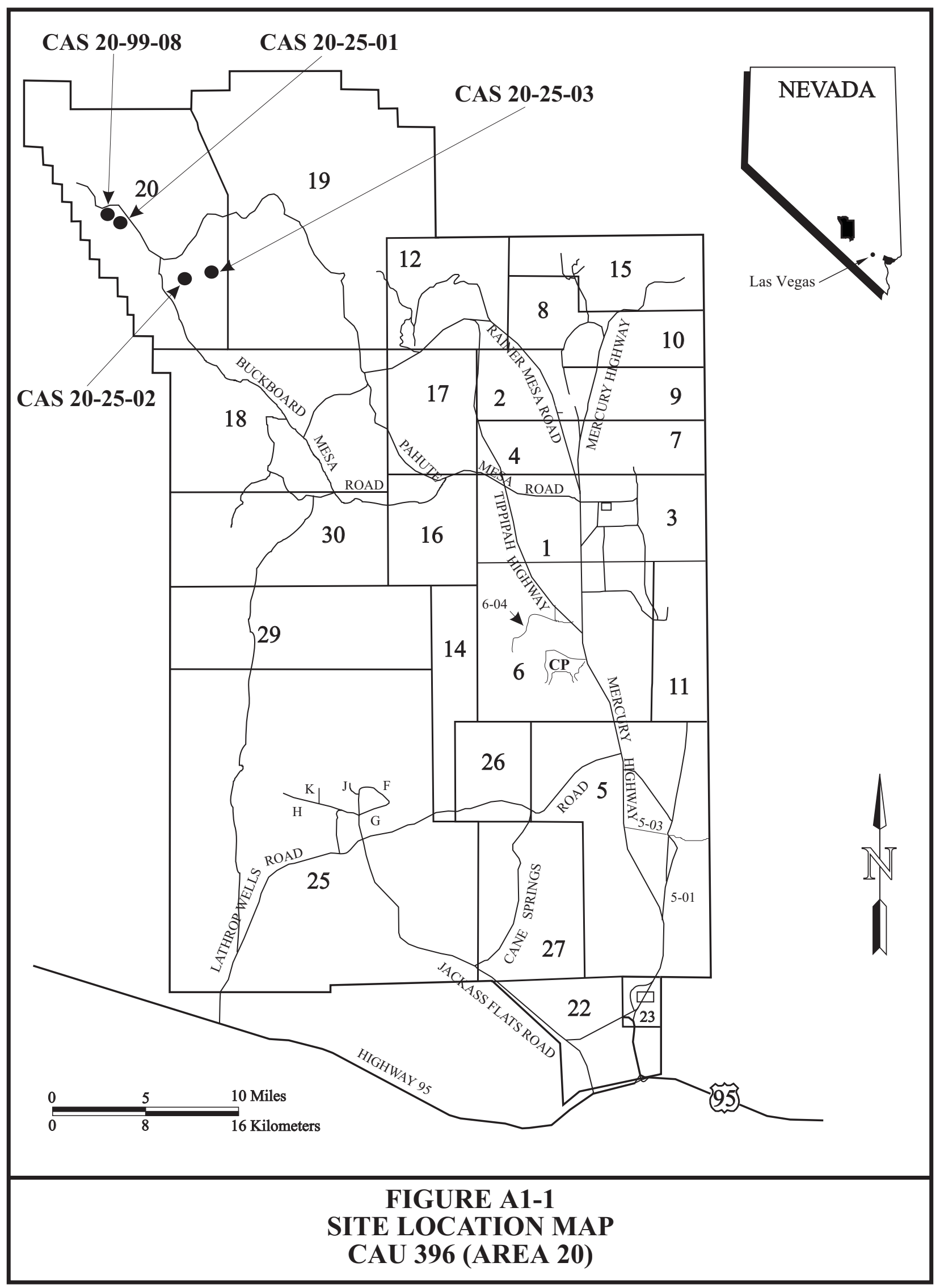




\subsubsection{CAS 20-25-01, Oil Spills (2)}

This CAS is located near Pahute Mesa Road on the Radiological Safety Marker (RSM) P 130 road, approximately 1.1 kilometers $(\mathrm{km})(0.7$ miles [mi]) from the intersection with Pahute Mesa Road. It is marked with the sign U-20bc cellar. One of the spill areas is located next to the cellar; the other spill area is located 9.1 meters $(\mathrm{m})(30$ feet $[\mathrm{ft}])$ north of the cellar. The estimated length and width of the two major spill areas (each consisting of numerous spills) is 11 by $21.9 \mathrm{~m}(36$ by $72 \mathrm{ft})$ and 6.1 by $6.1 \mathrm{~m}(20$ by $20 \mathrm{ft})$.

Historical information for this CAS is limited. It is believed that these oil spills are associated with drilling operations at the U-20bc post-test cellar, which was drilled between November 6, 1989 and November 7, 1989 (Raytheon Services Nevada [RSN], 1991). Unknown items include the volume of liquid spilled and the current dimensions of impacted soil.

Samples from sites in CAU 396 were collected between August 26, 1997 and August 28, 1997 by the International Technology Corporation (IT) Preliminary Assessment Group. One sample was collected from the spill area closest to the U-20bc cellar. The sample was analyzed for VOCs, SVOCs, TPH, PCBs, RCRA metals, and gamma-emitting radionuclides. The sample showed a TPH concentration of 35,000 milligrams per kilogram ( $\mathrm{mg} / \mathrm{kg})$, and an arsenic concentration above the EPA Region IX preliminary remediation goals (PRG's) for industrial soils. Although the arsenic level exceeds the PRG's, the concentration measured is consistent with background levels normally found at the NTS.

\subsubsection{CAS 20-25-02, Oil Spills}

This CAS is located by traveling west on Buckboard Mesa Road. Turn right (east) on Pahute Mesa Road and proceed approximately $2.7 \mathrm{~km}(1.7 \mathrm{mi})$ to a dirt road on the south (right). The spill area is just north east of the U-20ax tower. During a site visit on August 1, 2001, it was determined that the spills may have been backfilled and covered with pea size gravel.

Historical information for this CAS is limited. It is believed that these spills are associated with drilling operations of the U-20ax emplacement hole, between June 19, 1987 and August 18, 1987 (RSN, 1991). Unknown items include the volume of liquid spilled and the current dimensions of impacted soil.

Samples from sites in CAU 396 were collected between August 26, 1997 and August 28, 1997 by the IT Preliminary Assessment group. One sample was collected approximately $50 \mathrm{ft}$ north the U-20ax drilling tower. The sample was analyzed for VOCs, SVOCs, TPH, PCBs, total RCRA metals, and gamma-emitting radionuclides. The only COPC present was arsenic. Although the arsenic level exceeds the PRG's, the concentration measured is consistent with background levels normally found at the NTS. 


\subsubsection{CAS 20-25-03, Oil Spill}

This CAS is located by proceeding west on Pahute Mesa Road to the UE-20bh1 sign. Turn left (south) on the dirt road across from the sign and follow the dirt road to the U-20az cellar. The oil spill area consists of numerous spills, that are located around the U-20az post-test cellar.

Historical information for this CAS is limited. It is believed that these spills are associated with drilling operations of the U-20az post test hole, between December 14, 1990 and December 16, 1990 (RSN, 1991). Unknown items include the volume of liquid spilled and the current dimensions of impacted soil.

Samples from sites in CAU 396 were collected between August 26, 1997 and August 28, 1997 by the IT Preliminary Assessment group. Four samples, including two duplicates, were collected from the spills located around the U-20az post test cellar. These samples were analyzed for VOCs, SVOCs, TPH, PCBs, RCRA metals, and gamma-emitting radionuclides. All of the samples showed TPH concentrations greater than $50,000 \mathrm{mg} / \mathrm{kg}$. The highest sample value found was $70,000 \mathrm{mg} / \mathrm{kg}$. Arsenic was also measured above the PRG's, but the concentrations measured are consistent with background levels normally found at the NTS.

\subsubsection{CAS 20-99-08, Spill}

This CAS is located by proceeding west on Pahute Mesa Road. Turn left (west) on Airport Road, and proceed to Pahute Mesa Road. Turn left (northwest) on Pahute Mesa Road and proceed to RSM P 130. Turn left (west) on the dirt road and proceed $0.8 \mathrm{~km}(0.5 \mathrm{mi})$ to the fork. Turn left (west) at the fork and proceed about $0.3 \mathrm{~km}(0.2 \mathrm{mi})$ past U-20bc. The spill is located near the U-20bc emplacement hole, south of the U-20bc post test cellar. During a site visit on August 28, 1997, it was noted that the spill is surrounded on three sides by a large bermed area.

Historical information for this CAS is limited. It is believed that this spill is associated with drilling operations of the U-20bc, between April 5, 1988 to June 28, 1988, or from the U-20bc post-test hole that was drilled between November 5, 1989 to November 6, 1989 (RSN, 1991). Unknown items include the volume of liquid spilled, and the current dimensions of impacted soil.

Samples from sites in CAU 396 were collected between August 26, 1997 and August 28, 1997 by the IT Preliminary Assessment group. One composite sample was collected near the U-20bc emplacement hole, south of the U-20bc post test cellar. The sample was analyzed for VOCs, SVOCs, TPH, PCBs, RCRA metals, and gamma-emitting radionuclides. The sample showed a PCB concentration of $99 \mathrm{mg} / \mathrm{kg}$ and an arsenic concentration above the PRGs. Although arsenic exceeds the PRGs, the concentration measured is consistent with background levels normally found at the NTS. 


\subsection{Develop and Refine the Conceptual Site Model}

The CSMs are considered the most probable scenarios for current conditions at the CAU 396 sites. Available information from which the CSMs are based were derived from process knowledge, related sites, site investigation, and environmental sampling analysis results. All of the sites are expected to fit the basic CSMs which pertain to that particular CAS with minor variations.

An important element of a CSM is the expected fate and transport of contaminants as they move through site media, and where they can be expected in the environment. The expected fate and transport is based on distinguishing physical characteristics of the contaminants and media, such as solubility of the contaminant, density, and particle size of the media. Ultimately, migration of contaminants to groundwater is limited by the geophysical properties such as permeability, porosity, and hydrologic conductivity. Groundwater contamination is not considered a likely scenario at CAU 396 based on the following information.

\subsubsection{Primary CSMs}

The following primary CSMs have been developed for CAU 396.

- $\quad$ For CAS 20-25-01, Oil Spills (2): The primary CSM assumes that only petroleum hydrocarbons were released to the soil. It also assumes that the vertical extent of contamination can be defined within the capability of a geoprobe 3.1 to $4.6 \mathrm{~m}$ (10 to $15 \mathrm{ft}$ ) max depth (Figure A1-2). The estimated length and width of the two major spill areas (each consisting of numerous spills) is 11 by $21.9 \mathrm{~m}$ (36 by $72 \mathrm{ft}$ ) and 6.1 by $6.1 \mathrm{~m}(20$ by $20 \mathrm{ft})$.

- $\quad$ For CAS 20-25-02, Oil Spills: The primary CSM assumes that only petroleum hydrocarbons were released to the soil. It also assumes that the vertical extent of contamination can be defined within the capability of a geoprobe 3.1 to $4.6 \mathrm{~m}$ (10 to $15 \mathrm{ft}$ ) max depth, and that these spills have not been excavated and are located below an estimated 25.4 centimeters (cm) (10 inches [in]) layer of pea sized gravel and fill material (Figure A1-3). The estimated length and width of this spill area is 18.3 by $23.2 \mathrm{~m}$ (60 by $76 \mathrm{ft})$.

- $\quad$ For CAS 20-25-03,Oil Spill: The primary CSM assumes that only petroleum hydrocarbons were released to the soil. It also assumes that the vertical extent of contamination can be defined within the capability of a geoprobe 3.1 to $4.6 \mathrm{~m}$ (10 to15 ft) max depth (Figure A1-2). The estimated length and width of this spill area is 15.2 by $15.2 \mathrm{~m}(50$ by $50 \mathrm{ft})$. 


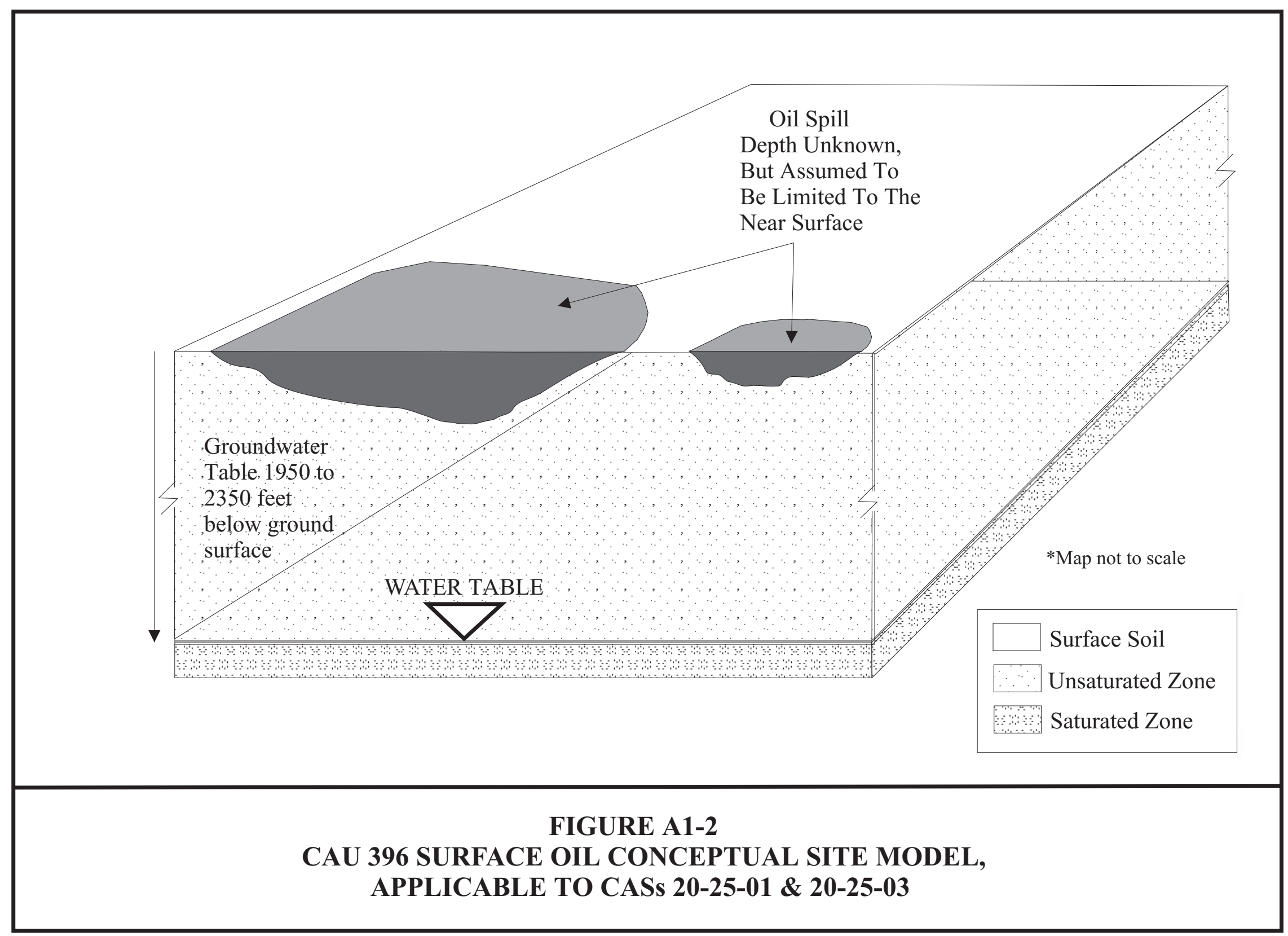




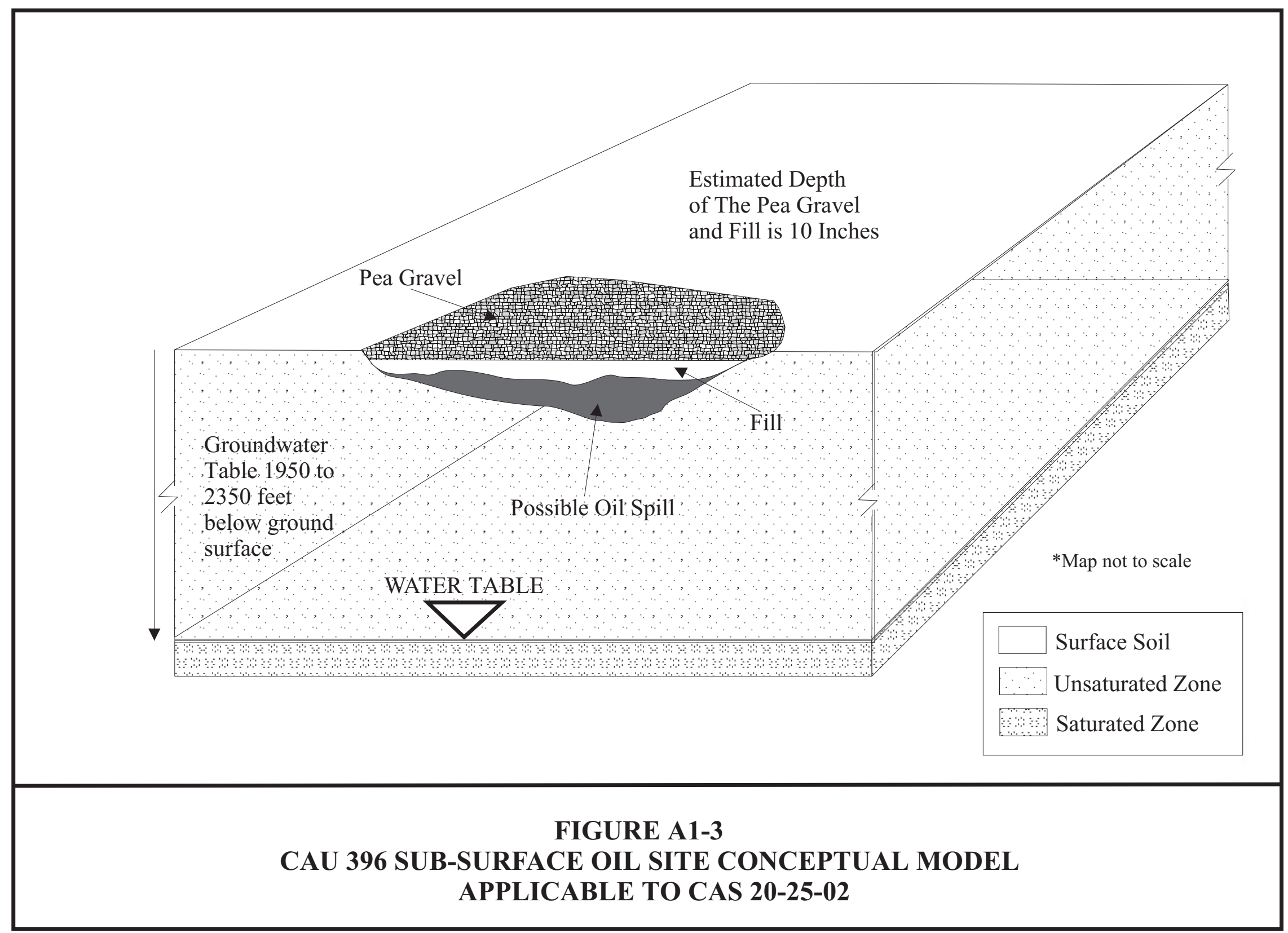


- $\quad$ For CAS 20-99-08, Spill: The primary CSM assumes that only PCB's were released to the soil. It also assumes that the vertical extent of contamination can be defined within the capability of a geoprobe 3.1 to $4.6 \mathrm{~m}$ (10 to $15 \mathrm{ft}$ ) max depth (Figure A1-4). The estimated length and width of this spill is 38.1 by $38.1 \mathrm{~m}$ (125 by $125 \mathrm{ft})$.

These CSMs include the following information that applies to all of the sites:

The CASs within CAU 396 are all located within Area 20. Area 20 was added to the NTS in 1963 to provide an area where deep underground weapon tests could be conducted (DOE/NV, 1988). Because of the unique nature of the historic activities performed at these sites, access will likely be further controlled from any use other than weapons testing. Therefore, contact with the CASs in CAU 396 by members of the public will not occur, and there will be no uncontrolled contact with these CASs by NTS personnel.

Area 20 of the NTS is located in the Pahute Mesa, which includes a broad volcanic plateau underlain by tuffs and lavas from the Timber Mountain Oasis Valley caldera complex and the Silent Canyon and Black Mountain calderas north of Timber Mountain. This Miocene, rhyolitic, eruptive center produced an overlapping complex of fault-controlled calderas in the general area of Timber Mountain and Pahute Mesa (DOE/NV, 1996). The mesa is an area of relatively low relief, with altitudes ranging from about 1676 to $2134 \mathrm{~m}(5,500$ to 7,000 ft) above sea level (DOE/NV, 1988).

Static water levels for the Pahute Mesa inside the caldera range from 594 to $716 \mathrm{~m}$ $(1,950$ to $2,350 \mathrm{ft})$ beneath the ground surface. Outside the caldera, the depth of the groundwater decreases to around $259 \mathrm{~m}(850 \mathrm{ft})$ in the extreme northwest corner of the NTS. The permeability of the rock is generally low; groundwater movement is primarily through fractures in the rock. Groundwater flow is generally south to southwest to the Oasis Valley, about 20 miles away (DOE/NV, 1988).

The NTS is one of the most arid regions of the United States. No surface water features or expression of erosional activity exist at any of the CASs. The annual average precipitation for area 20, Pahute Mesa, is 20.02 centimeter per year $(\mathrm{cm} / \mathrm{y})(7.88$ inches per year $[\mathrm{in} / \mathrm{y}])$ (Pahute Mesa 1 monitoring station). This station has been monitored since 1964. 


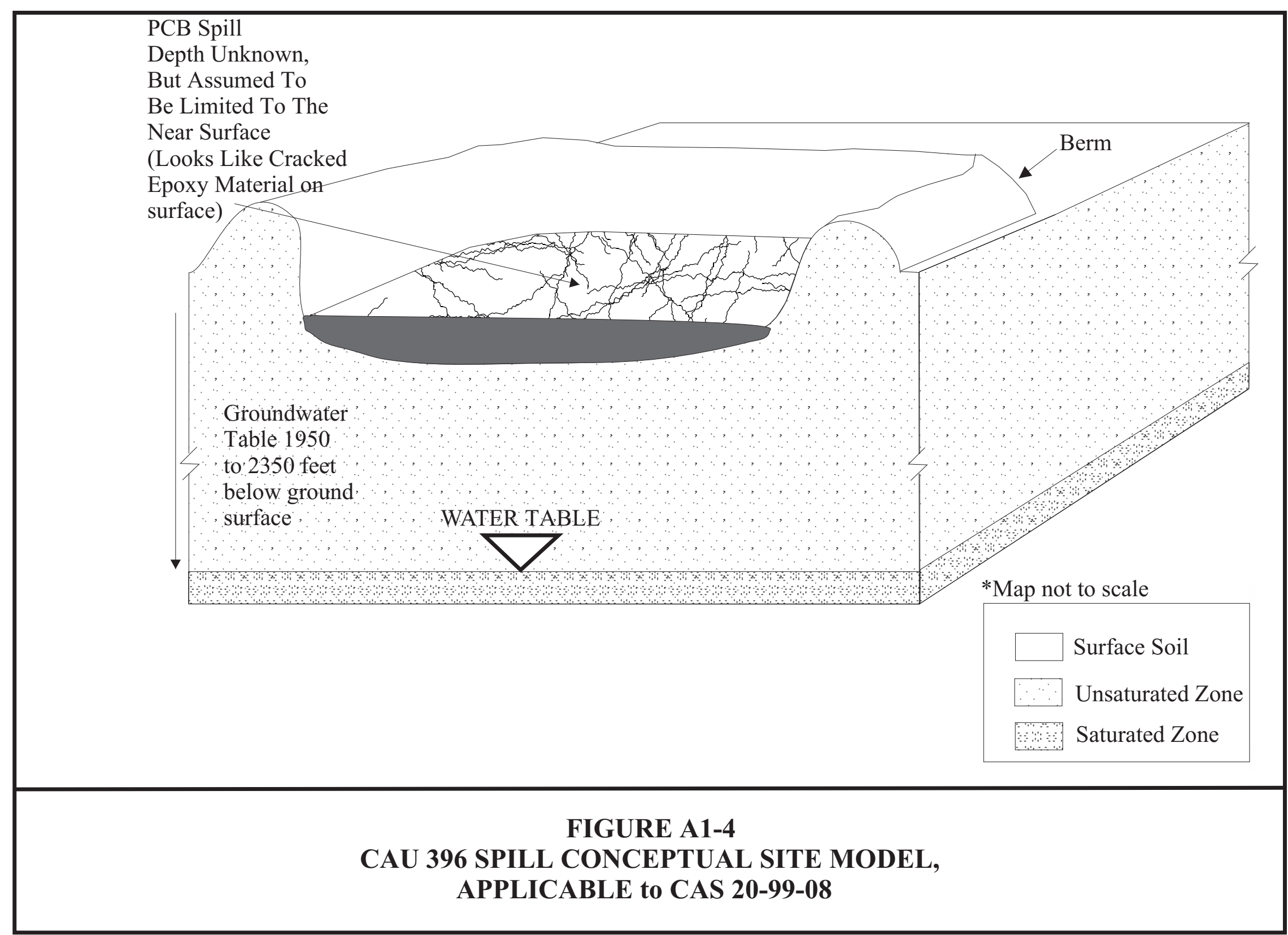




\subsubsection{CAS Specific Variations to the Primary CSMs}

Table A1 summarizes the basic variations to the primary CSMs for all of the sites.

\section{TABLE A1 - SUMMARY OF CAU 396 CAS STATUS}

\begin{tabular}{|c|c|c|c|c|}
\hline & & SPILLS & & \\
\hline CAS & $\begin{array}{c}\text { BY GRAVEL } \\
\text { AND } \\
\text { BACKFILL }\end{array}$ & ON SURFACE & $\begin{array}{c}\text { TPH } \\
\text { CONTAMINATION }\end{array}$ & $\begin{array}{c}\text { PCB } \\
\text { CONTAMINATION }\end{array}$ \\
\hline $20-25-01$ & & $\mathrm{X}$ & $X$ & \\
\hline $20-25-02$ & $\mathrm{X}$ & & & \\
\hline $20-25-03$ & & $X$ & $X$ & \\
\hline 20-99-08 & & $X$ & & $X$ \\
\hline
\end{tabular}

Note: An X indicates that this is applicable to this CAS.

\subsubsection{Alternate CSMs}

- The conditions under the alternate CSM are considered less likely than conditions outlined in the primary CSMs. The alternate CSM for all of the CASs in CAU 396 are listed below:

- $\quad$ For CAS 20-25-01, Oil Spills (2): The alternate CSM provides for a release of other contaminants of concern (COCs) found in conjunction with the waste oil. If these COCs are above the action level, TPH field screening will be used to determine the boundaries of the TPH impacted soil. It also provides for a petroleum hydrocarbon release with a vertical extent of contamination deeper than can be defined within the capability of a geoprobe. Methods capable of obtaining deeper samples will be evaluated such as using a drill rig.

- $\quad$ For CAS 20-25-02, Oil Spills: The alternate CSM provides for a release of other COCs found in conjunction with the waste oil. If these COCs are above the action level, TPH field screening will be used to determine the boundaries of the TPH impacted soil. It also provides for a petroleum hydrocarbon release with a vertical extent of contamination deeper than can be defined within the capability of a geoprobe. Methods capable of obtaining deeper samples will be evaluated such as using a drill rig. 
- $\quad$ For CAS 20-25-03,Oil Spill: The alternate CSM provides for a release of other COCs found in conjunction with the waste oil. If these COCs are above the action level, TPH field screening will be used to determine the boundaries of the TPH impacted soil. It also provides for a petroleum hydrocarbon release with a vertical extent of contamination deeper than can be defined within the capability of a geoprobe. Methods capable of obtaining deeper samples will be evaluated such as using a drill rig.

- $\quad$ For CAS 20-99-08, Spill: The alternate CSM provides for a release of other COCs found in conjunction with the PCB impacted material. If these COCs are above the action level, sampling (Dexsil field screening or Gas Chromatograph [GC] method) will be used to determine the boundaries of the PCB impacted soil/material. It also provides for a PCB release with a vertical extent of contamination deeper than can be defined within the capability of a geoprobe. Methods capable of obtaining deeper samples will be evaluated such as using a drill rig.

\subsection{IDENTIFY THE DECISION}

In this step, the principal study question will be made into a decision statement that will address the problem as previously described.

\subsection{Identify the Principal Study Question}

The principal study question is, "Does any CAS within CAU 396 pose an unacceptable risk to human health/environment?"

\subsection{Alternative Actions that Could Result from Resolving the Principal Study Question}

The possible actions that may result include:

- $\quad$ Clean closure of the site based on unacceptable risk to human health or the environment.

- No further action with administrative controls based on unacceptable risk to human health for potential future site workers.

- No further action based on an acceptable risk to human health and the environment.

\subsection{Decision Statement}

Combining the principal study question with the alternative actions generates the following decision statement:

"Determine if the CASs within CAU 396 have a risk to human health or the environment and thus require some type of corrective action." 


\subsection{IDENTIFY THE INPUTS TO THE DECISION}

\subsection{Information Required to Resolve the Decision Statement}

Relevant information that bears on the decision statement will be defined on a case to case basis. The relevant information will clarify the nature and extent of COCs at each site. This information will include process knowledge, information from similar sites, and analytical sampling using an appropriate analytical method for potential COCs at each CAS. The future land use and potential receptors must be identified. Any missing data relevant to the decision statement must also be identified.

General information that applies to each CAS includes the PRGs (EPA, 2002) for industrial soils to aid in the determination of risk to human health and the environment, The Nevada Administrative Code (NAC) 445A.2272 for action levels for petroleum hydrocarbons (NAC, 2002), and Title 40 CFR 761, "Polychlorinated Biphenyls (PCBs) Manufacturing, Processing, Distribution in Commerce, and use Prohibitions" (EPA, 2001).

All of these CASs are in Area 20 of the NTS which is designated as a weapons test zone. Because of the unique nature of the historic activities performed at these sites, access will likely be further controlled from any use other than weapons testing.

\subsubsection{CAS 20-25-01, Oil Spills (2) and 20-25-03, Oil Spill}

Total petroleum hydrocarbons in the oil range were found at both of these CASs. Previous work on TPH impacted soils at the NTS have demonstrated that TPH infiltration is relatively slow (NNSA/NSO, 2003) due to the low annual precipitation that the NTS receives as described in section 1.3.1. These spills are also thought to be associated with drilling activities that took place for only a few days to just over two months. Because of these factors, it is thought that the vertical extent of these spills are shallow and can be determined with a geoprobe 3.1 to $4.6 \mathrm{~m}$ (19 to $15 \mathrm{ft}$ ) max depth as stated in section 1.3.1. At CAS 20-25-01, only one sample was taken with in the larger spill area. At CAS 20-25-03, only two of the spills in the spill area were sampled. Because of these data gaps for the spill areas that have not been sampled, their nature is not known.

\subsubsection{0-25-02, Oil Spills}

It is believed that the spills in this area were covered up with $25.4 \mathrm{~cm}$ (10 in) of pea gravel and fill material, and that the gravel cover is about the same size as the spill area (90 by $114 \mathrm{ft}$ ). Although no COPCs were found, the sample collected at this site on August 26, 1997 was collected at a depth of $15.2 \mathrm{~cm}$ (6 in), and may not have been sampled deep enough to reach any contaminates. The data is also in question because the holding time for VOC's and SVOC's was exceeded, and the surrogate recovery for waste oil and diesel were outside the limits. 


\subsubsection{CAS 20-99-08, Spill}

Polychlorinated biphenyl (Aroclor-1248) was found at this CAS. Usually PCB's bind to soil particles and are thought to be relatively immobile. Because of this factor, it is thought that the vertical extent of this spill can be determined with a geoprobe 3.1 to $4.6 \mathrm{~m}$ (10 to15 ft) max depth as stated in section 1.3.1. Only one mixed sample of the epoxy like material and soil was taken with in this large spill area, and their was poor duplicate precision for RCRA metals. Because of this data gap, it is not known if the underlying soil is impacted.

\subsection{List types of COCs and Affected Media}

Only two COPCs were detected at CAU 396 sites. They were TPH in the oil range, and the PCB Aroclor 1248. For all CASs except 20-99-08, the affected media is soil. At CAS 20-99-08 the affected media is soil and an epoxy like material on the surface. Table A2 provides a summary of the sample analytical data.

\subsection{Identify Potential Sampling Approaches and Appropriate Analytical Methods}

\subsubsection{CAS 20-25-01: Oil Spills (2)}

The nature of both spill areas are not fully defined in this CAS. Their nature can be determined by taking one sample from spill area 1 , and two samples from spill area 2 . These samples will be analyzed by using EPA approved methods for VOCs (8260B), SVOCs (8270C), TPH (8015B), PCBs (8082), RCRA metals (6010B 7000 series), and gamma-emitting radionuclides (HASL 300, 4.5.2.3).

If TPH is the only COC found, the horizontal extent of each spill area will be identified on four sides by the following method. Samples will be collected from the apparent edge of the spill

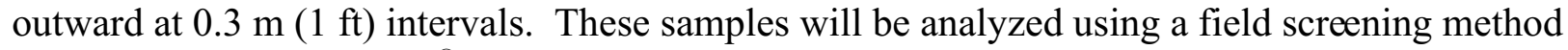
(developed by PetroFLAG ${ }^{\circledR}$ ) until two consecutive samples are found at or below the $100 \mathrm{mg} / \mathrm{kg}$ action level for TPH. The PetroFLAG ${ }^{\circledR}$ field screening method has been used extensively on other CASs at the NTS and produces conservative results for the presence of petroleum hydrocarbons in soil. The vertical extent of each spill will be determined by using a geoprobe to collect a sample from the center of each spill area. These samples will also by analyzed at one foot intervals with PetroFLAGs ${ }^{\circledR}$ until two consecutive samples are found at or below the $100 \mathrm{mg} / \mathrm{kg}$ action level for TPH. If a geoprobe is inadequate to determine the vertical extent of the spill, other options will be evaluated such as using a drill rig.

Once the estimated volume of impacted soil has been excavated, a number of verification samples will be collected and screened for TPH (PetroFLAG ${ }^{\circledR}$ or equivalent) to determine if all of the TPH impacted soil has been removed from the site. When PetroFLAG ${ }^{\circledR}$ screening indicates that TPH concentrations are at or below $100 \mathrm{mg} / \mathrm{kg}$, excavation activities will be suspended and verification samples will be collected. After all of the contaminated soil that is above the action limit has been excavated, confirmatory samples will be collected and analyzed 
for TPH (using analytical method 8015B modified EPA, 1996) to confirm the PetroFLAG ${ }^{\circledR}$ results and verify that the impacted soils have been removed.

If other COCs are found in conjunction with the waste oil, oil will be assumed to be the carrier. PetroFLAG $^{\circledR}$ TPH field screening will be used to determine the boundaries of TPH impacted soil. Once the extent is determined, a confirmatory sample will be collected and analyzed for TPH and any other COCs previously identified. The confirmatory sample method can be found in Table 1 of the SAFER.

\subsubsection{CAS 20-25-02: Oil Spills}

The nature and extent of the spills in this area are not defined. In order to determine if there is contaminated soil in this area, three exploratory holes will be excavated through the pea gravel and fill material and analyzed using EPA approved methods for VOCs (8260B), SVOCs (8270C), TPH (8015B), PCBs (8082), RCRA metals (6010B 7000 series), and gamma-emitting radionuclides (HASL 300, 4.5.2.3). In addition to the three biased samples, a 3 by $3 \mathrm{~m}$ (10 by10 ft) grid sampling approach will be used. The boundaries of this grid will be the spill area as defined by the original spill dimensions of 18.3 by $23.2 \mathrm{~m}$ ( 60 by $76 \mathrm{ft})$. Twenty randomly chosen samples will be taken from the center of these squares and analyzed using PetroFLAGS ${ }^{\circledR}$.

If TPH is the only COC found, the horizontal extent of the spill area will be identified on four sides by the following method. Samples will be collected $1.5 \mathrm{~m}(5 \mathrm{ft})$ inside the original dimensions of the spill area and outward at $0.3 \mathrm{~m}(1 \mathrm{ft})$ intervals. These samples will be analyzed using the PetroFLAG ${ }^{\mathbb{R}}$ screening method until two consecutive samples are found at or below the $100 \mathrm{mg} / \mathrm{kg}$ action level for TPH. The vertical extent of each spill will be determined by using a geoprobe to collect a sample from the center of each spill area. These samples will also by analyzed at $0.3 \mathrm{~m}(1 \mathrm{ft})$ intervals with PetroFLAGs ${ }^{\mathbb{R}}$ until two consecutive samples are found at or below the $100 \mathrm{mg} / \mathrm{kg}$ action level for TPH. If a geoprobe is inadequate to determine the vertical extent of the spill, other options will be evaluated such as using a drill rig.

Once the estimated volume of impacted soil has been excavated, a number of verification samples will be collected and screened for TPH PetroFLAG ${ }^{\mathbb{R}}$ or equivalent) to determine if all of the TPH impacted soil has been removed from the site. When PetroFLAG ${ }^{\circledR}$ screening indicates that TPH concentrations are at or below $100 \mathrm{mg} / \mathrm{kg}$, excavation activities will be suspended and verification samples will be collected. After all of the contaminated soil that is above the action limit has been excavated, confirmatory samples will be collected and analyzed for TPH (using analytical method 8015B modified EPA, 1996) to confirm the PetroFLAG ${ }^{\circledR}$ results and verify that the impacted soils have been removed. 
TABLE A2 - CAU 396 SAMPLE ANALYTICAL RESULTS

\begin{tabular}{|c|c|c|c|c|c|c|c|c|}
\hline $\begin{array}{c}\text { SAMPLE } \\
\text { IDENTIFICATION } \\
\text { NUMBER }\end{array}$ & $\begin{array}{l}\text { DIESEL } \\
(\mathrm{mg} / \mathrm{kg})^{\mathrm{a}}\end{array}$ & $\begin{array}{c}\text { OIL } \\
(\mathrm{mg} / \mathrm{kg})\end{array}$ & $\begin{array}{c}\text { TPH }^{\mathbf{b}} \\
(\mathrm{mg} / \mathbf{k g})\end{array}$ & $\begin{array}{l}\mathrm{VOCs}^{\mathrm{c}} \\
(\mu \mathrm{g} / \mathbf{k g})^{\mathrm{d}}\end{array}$ & $\begin{array}{l}\text { SVOC }^{\mathrm{e}} \\
(\mu \mathrm{g} / \mathbf{k g})\end{array}$ & $\begin{array}{c}\text { Total RCRA } \\
\text { METALS } \\
(\mathrm{mg} / \mathrm{kg})\end{array}$ & $\begin{array}{c}\mathrm{PCBs}^{\mathrm{g}} \\
(\mathrm{mg} / \mathrm{kg})\end{array}$ & $\begin{array}{c}\text { GAMMA } \\
\text { SPECTROSCOPY } \\
(\mathbf{p C i} / \mathrm{g})^{\mathrm{h}}\end{array}$ \\
\hline $\begin{array}{l}\text { ANALYSIS } \\
\text { METHOD } \\
\end{array}$ & $\begin{array}{l}\text { EPA } \\
8015 \\
\end{array}$ & $\begin{array}{l}\text { EPA } \\
8015 \\
\end{array}$ & $\begin{array}{l}\text { EPA } \\
8015 \\
\end{array}$ & $\begin{array}{r}\text { EPA } \\
\text { 8260A } \\
\end{array}$ & $\begin{array}{l}\text { EPA } \\
8270 \\
\end{array}$ & $\begin{array}{c}\text { EPA } \\
6010 \& 7460 \\
\end{array}$ & $\begin{array}{l}\text { EPA } \\
8082 \\
\end{array}$ & $\begin{array}{c}\text { HASL } 300 \\
\text { SM } 7110 \\
\end{array}$ \\
\hline ACTION LEVEL & $\begin{array}{c}100 \\
\mathrm{mg} / \mathrm{kg}^{\mathrm{i}} \\
\end{array}$ & $\begin{array}{c}100 \\
\mathrm{mg} / \mathrm{kg}^{\mathrm{i}} \\
\end{array}$ & $100 \mathrm{mg} / \mathbf{k g}^{\mathrm{i}}$ & $\begin{array}{c}\text { EPA } \\
\text { PRGs }^{\mathrm{j}} \\
\end{array}$ & $\begin{array}{c}\text { EPA } \\
\text { PRGs }^{\mathrm{j}} \\
\end{array}$ & $\begin{array}{c}\text { EPA } \\
\text { PRGs }^{\mathrm{j}} \\
\end{array}$ & $\mathbf{T S C A}^{\circ}$ & NTS Background $^{k}$ \\
\hline \multicolumn{9}{|c|}{ CAS 20-25-01 (SDG' 15718) } \\
\hline ERS00079 & $\mathrm{ND}^{\mathrm{m}}$ & 35,000 & 35,000 & $\begin{array}{c}<\text { Action } \\
\text { levels }\end{array}$ & $\begin{array}{c}<\text { Action } \\
\text { levels }\end{array}$ & $<$ Action levels $^{\mathrm{n}}$ & $\begin{array}{c}<\text { Action } \\
\text { levels }\end{array}$ & $\begin{array}{c}\text { NTS Background } \\
\text { levels }\end{array}$ \\
\hline \multicolumn{9}{|c|}{ CAS 20-25-02 (SDG 15718) } \\
\hline ERS00080 & ND & ND & ND & $\begin{array}{c}<\text { Action } \\
\text { levels }\end{array}$ & $\begin{array}{c}<\text { Action } \\
\text { levels }\end{array}$ & $\begin{array}{l}<\text { Action } \\
\text { levels }\end{array}$ & $\begin{array}{l}<\text { Action } \\
\text { levels }\end{array}$ & $\begin{array}{c}\text { NTS Background } \\
\text { levels }\end{array}$ \\
\hline \multicolumn{9}{|c|}{ CAS 20-25-03 (SDG 15720) } \\
\hline ERS00173 & ND & 50,000 & 50,000 & \multirow{4}{*}{$\begin{array}{l}<\text { Action } \\
\text { levels }\end{array}$} & \multirow{4}{*}{$\begin{array}{c}<\text { Action } \\
\text { levels }\end{array}$} & \multirow{4}{*}{$\begin{array}{l}<\text { Action } \\
\text { levels }^{\mathrm{n}}\end{array}$} & \multirow{4}{*}{$\begin{array}{l}<\text { Action } \\
\text { levels }\end{array}$} & \multirow{4}{*}{$\begin{array}{l}\text { NTS Background } \\
\text { levels }\end{array}$} \\
\hline ERS00174 (DUP 173) & ND & 63,000 & 63,000 & & & & & \\
\hline ERS00175 & $\mathrm{ND}$ & 70,000 & 70,000 & & & & & \\
\hline RS00176 (DUP 175) & ND & 57,000 & 57,000 & & & & & \\
\hline \multicolumn{9}{|c|}{ CAS 20-99-08 (SDG 15720) } \\
\hline ERS00178 & ND & ND & ND & $\begin{array}{c}<\text { Action } \\
\text { levels }\end{array}$ & $\begin{array}{c}<\text { Action } \\
\text { levels }\end{array}$ & $\begin{array}{c}<\text { Action } \\
\text { levels }^{\mathrm{n}}\end{array}$ & 99 & $\begin{array}{l}\text { NTS Background } \\
\text { levels }\end{array}$ \\
\hline \multirow{2}{*}{\multicolumn{9}{|c|}{$\begin{array}{ll}\text { amilligrams per kilogram } & { }^{\mathrm{k}} \text { Background levels established in McArther and Miller, 1989. } \\
{ }^{\mathrm{b}} \text { Total petroleum hydrocarbons } & { }^{\mathrm{l}} \text { Sample Delivery Group } \\
{ }^{\mathrm{c}} \text { Volatile organic compounds } & { }^{\mathrm{m}} \text { Not detected at the lab oratory rep orting limit } \\
{ }^{\mathrm{d}} \text { Micrograms per kilogram } & { }^{\mathrm{n}} \text { Although arsenic excee ds the PR Gs, the con centration measured is co nsistent with } \\
\text { e Semivolatile organic compounds } & \text { background levels normally found at the NTS. }\end{array}$}} \\
\hline & & & & & & & & \\
\hline \multicolumn{4}{|c|}{$\begin{array}{l}{ }^{\mathrm{f}} \text { Resource Conservation and Recovery Act } \\
\text { g Polychlorinated biph enyls } \\
{ }^{\mathrm{h}} \text { picocuries per gram }\end{array}$} & \multicolumn{2}{|c|}{$\begin{array}{r}{ }^{\circ} \text { U.S. Environmental } \\
761, " \mathrm{P} \text { olycl } \\
\text { Comm erce, } \\
\text { DUP = duplica te }\end{array}$} & $\begin{array}{l}\text { otection Agency } 20 \\
\text { rinate d Biphe nyls M } \\
\text { d u se Prohib itions." }\end{array}$ & $\begin{array}{l}\text { Title } 40 \mathrm{Co} \\
\text { nu facturing, } \\
\text { Iashington, I }\end{array}$ & $\begin{array}{l}\text { ef Federal Regulations } \\
\text { ro cessing, Distribution in } \\
\text { C. }\end{array}$ \\
\hline
\end{tabular}


If other COCs are found in conjunction with the waste oil, oil will be assumed to be the carrier. PetroFLAG $^{\circledR}$ TPH field screening will be used to determine the boundaries of TPH impacted soil. Once the extent is determined, a confirmatory sample will be collected and analyzed for TPH and any other COCs previously identified. The confirmatory sample method can be found in Table 1 of the SAFER.

\subsubsection{CAS 20-25-03: Oil Spill}

The nature of two of the spills in this area are partially defined, however the others are not. Their nature can be determined by taking a sample, from each spill, and analyzing them using EPA approved methods for VOCs (8260B), SVOCs (8270C), TPH (8015B), PCBs (8082), RCRA metals (6010B 7000 series), and gamma-emitting radionuclides (HASL 300, 4.5.2.3). If the first sample does not show any COCs a second sample will be collected and analyzed for the full range of COPCs described above.

If TPH is the only COC found, the horizontal extent of each spill area will be identified on four sides by the following method. Samples will be collected from the apparent edge of the spill outward at $0.3 \mathrm{~m}(1 \mathrm{ft})$ intervals. These samples will be analyzed using the PetroFLAG ${ }^{\circledR}$ field screening method, until two consecutive samples are found at or below the $100 \mathrm{mg} / \mathrm{kg}$ action level for TPH. The vertical extent of each spill will be determined by using a geoprobe to collect a sample from the center of each spill area. These samples will also by analyzed at one foot intervals with PetroFLAGs ${ }^{\circledR}$, until two consecutive samples are found at or below the $100 \mathrm{mg} / \mathrm{kg}$ action level for TPH. If a geoprobe is inadequate to determine the vertical extent of the spill, other options will be evaluated such as using a drill rig.

Once the estimated volume of impacted soil has been excavated, a number of verification samples will be collected and screened for TPH (PetroFLAG ${ }^{\circledR}$ or equivalent) to determine if all of the TPH impacted soil has been removed from the site. When PetroFLAG ${ }^{\circledR}$ screening indicates that TPH concentrations are at or below $100 \mathrm{mg} / \mathrm{kg}$, excavation activities will be suspended and verification samples will be collected. After all of the contaminated soil that is above the action limit has been excavated, confirmatory samples will be collected and analyzed for TPH (using analytical method 8015B modified EPA, 1996) to confirm the PetroFLAG ${ }^{\circledR}$ results and verify that the impacted soils have been removed.

If other COCs are found in conjunction with the waste oil, oil will be assumed to be the carrier. PetroFLAG ${ }^{\circledR}$ TPH field screening will be used to determine the boundaries of TPH impacted soil. Once the extent is determined, a confirmatory sample will be collected and analyzed for TPH and any other COCs previously identified. The confirmatory sample method can be found in Table 1 of the SAFER. 


\subsubsection{CAS 20-99-08: Spill}

The nature and extent of this spill is not fully defined. The nature can be determined by taking three soil samples, and three samples of the material on the surface from this spill area, and analyzing them using EPA approved methods for PCBs (8082) and RCRA metals (6010B 7000 series).

If PCB is the only COC found, the horizontal extent of this spill will be identified on four sides by the following method. Samples will be collected from the apparent edge of the spill outward at $0.3 \mathrm{~m}(1 \mathrm{ft})$ intervals. These samples will be analyzed using a field screening method developed by the Dexsil Corporation, or a GC method. The samples will be analyzed until two consecutive samples are found at or below the $25 \mathrm{mg} / \mathrm{kg}$ action level for PCB bulk remediation waste in low occupancy areas (EPA, 2001). The vertical extent of this spill will be determined by using a geoprobe to collect a sample from the center of the spill. These samples will also by analyzed at $0.3 \mathrm{~m}(1 \mathrm{ft})$ intervals using a field screening method developed method developed by the Dexsil Corporation, or a GC method until two consecutive samples are found at or below the $25 \mathrm{mg} / \mathrm{kg}$ action level for PCB bulk remediation waste in low occupancy areas (EPA, 2001). If a geoprobe is inadequate to determine the vertical extent of the spill, other options will be evaluated such as using a drill rig.

Once the estimated volume of soil/material has been excavated, a number of verification samples will be collected and screened for PCBs (Dexsil or GC method) to determine if all of the PCB impacted soil/material has been removed from the site. When the screening indicates that PCB concentrations are at or below $25 \mathrm{mg} / \mathrm{kg}$ excavation activities will be suspended and verification samples will be collected. After all of the contaminated soil/material that is above the action limit has been excavated, verification samples will be collected by following all of the EPA regulations that are stated in Title 40 CFR 761.130 ,"Sampling Requirements." (EPA, 2001). If other COCs are found in conjunction with the PCB impacted material, the material will be assumed to be the carrier. PCB field screening or a GC method will be used to determine the boundaries of the PCB impacted soil. Once the extent is determined, confirmatory samples will be collected and analyzed for PCB and any other COCs previously identified. The confirmatory sample method can be found in Table 1 of the SAFER.

\subsection{DEFINE THE BOUNDARIES OF THE STUDY}

\subsection{Define the Geographic Areas of the Field Investigation}

All of the CASs withing CAU 396 are located within Area 20 of the NTS. The geographic areas of the field investigation are those areas of each CAS which are impacted by COCs as identified by the CSM in section 1.3.1. Descriptions of each area are found in Section 1.2 of this report. The boundaries in all cases are limited to the FFACO CAS description. 


\subsubsection{Define the Geographic Area Within Which all Decisions Must Apply}

The geographic areas of the field investigation are those areas of each CAS which are impacted by COCs as identified by the CSM in section 1.3.1. Descriptions of each area are found in Section 1.2 of this report. The boundaries in all cases are limited to the FFACO CAS description.

\subsubsection{Specify the Characteristics that Define the Population of Interest}

The population of interest is the concentration of COCs associated with each CAS and its associated risk to human health and the environment.

\subsection{Define the Time Frame of the Decision}

\subsubsection{Determine the Time Frame to Which the Study Data Apply}

- $\quad$ The study data should be relevant to the length of time allowed by the Streamlined Approach for Environmental Restoration (SAFER) process under the FFACO (FFACO, 1996).

- $\quad$ Migration (if occurring) is assumed to be imperceptibly slow. This is based on minimal surface water infiltration for TPH, and PCB's affinity to bind with soil particles.

\subsubsection{Determine When to Collect Data}

Field activities are scheduled to take place after approval of the final SAFER Plan. A date for field activities has not been formally determined. Field activities will be conducted at times that meet the security and safety constraints of the NTS.

\subsubsection{Define Relevant Time Constraints}

The FFACO deadline for delivery of the final SAFER Plan is March 31, 2003. The FFACO deadline of delivery for the final Closure Report has not been formally determined.

\subsection{Identify any Practical Constraints on Data Collection}

- $\quad$ Approval of the DQO process and the SAFER Plan by the NDEP

- $\quad$ Site operations - NTS operational and security constraints

- $\quad$ Equipment and personnel access

- $\quad$ Severe meteorological conditions

- $\quad$ Availability of resources (personnel and equipment)

- Health and safety of workers 


\subsection{DEVELOP A DECISION RULE-DEFINE A LOGICAL BASIS FOR CHOOSING AMONG ALTERNATIVE ACTIONS}

\subsection{Specify the Action Level or Preliminary Action Level for the Decision}

The action level is $100 \mathrm{mg} / \mathrm{kg}$ for TPH based on NAC 445A.2272 (NAC, 2002). All other action levels are based on the EPA Region IX PRGs for Industrial Soils (EPA, 2002). Chemical concentrations above the action levels do not automatically trigger a response action.

\subsection{Basis for Choosing Alternative Actions}

Alternative actions will be based on whether a COC exceeds an action level as described in Section 5.1. If an action level is exceeded, then future land use and potential impact to human health and the environment will be considered. If COCs exceed action levels and future land use indicates an exposure potential, then the action alternative will be clean closure. If COCs exceed action levels, future land use limits exposure, and there is limited risk to human health and the environment, then closure in place will be recommended. If COCs are not present above action levels, then no further action will be required.

\subsection{SPECIFY LIMITS ON THE DECISION ERRORS}

\subsection{Sources of Potential Decision Error}

Measurement error is influenced by imperfections in the measurement and analysis system. Random and systematic measurement errors can be introduced in the measurement process during physical sample collection, sample handling, sample preparation, sample analysis, and data reduction.

Errors introduced during sample collection and handling are minimized by developing a sampling and analysis plan. BN Environmental Restoration sampling plans are compliant with approved operational instructions for sample collection, field documentation, and equipment decontamination. Arsenic samples are collected, each sample is identified with a unique number. A custody seal is placed on the container. The "Services Request \& Chain of Custody Record" form is filled out and maintained.

Sample preparation and analysis errors are minimized by using an EPA-approved analytical method. Additionally, quality control samples are added to maintain the following:

- $\quad$ Accuracy - Closeness of a measurement or the mean of a set of results to the true value. Accuracy measures the bias of the measurement system. Indicators for measurement are based on the percent recoveries associated with the laboratory analytical control spikes, surrogate spikes, or matrix spikes. 
- Comparability - A qualitative judgement which expresses the confidence with which one set can be compared to another. Items used to determine comparability include the analytical method and reporting units.

- $\quad$ Completeness - Indicators for this measurement are the amount of valid data obtained from a measurement system compared to the amount that was expected and needed to be obtained to meet the project data goals.

- $\quad$ Precision - A measurement which represents the repeatability of the analytical system. Indicators for measurement are based on the relative percent difference (RPD) between field duplicates, laboratory splits, or laboratory replicate analysis. It is usually expressed as the RPD or standard deviation.

- $\quad$ Representativeness - A qualitative judgement which refers to a sample or group of samples that reflect the characteristics of the media at the sampling point. It also includes how well the sampling point represents the actual parameter variations which are under study.

\subsection{Limits on Decision Errors}

The proposed future sampling at CAU 396 will use a biased sampling approach. The biased sampling approach does not allow for the assessment of whether or not specific decision error rate limits have been attained. Therefore, for biased sampling, a decision error rate cannot be established. Because an error rate cann ot be established, the discus sion of Type I (false rejection of the null hypothesis) and Type II (false acceptance of the null hypothesis) is not meaningful. A valid null hypothesis, however, for each CAS in CAU 396 would be that COCs pose an unacceptable risk to human health and the environment.

\subsection{OPTIMIZE THE DESIGN - OUTLINE A SAMPLING DESIGN, SPECIFYING THE OPERATION DETAILS OF THE SAMPLING PLAN WHICH FALLS WITHIN THE PROJECTS CONSTRAINTS}

\subsection{Develop General Sampling and Analysis Design Alternatives}

Additional sampling will be conducted as described in section 3.3 in order to define the nature and extent of the spills in CAU 396.

\subsection{Select the Most Resource-effective Design that Satisfies All of the DQOs}

Additional samples will be collected as stated in section 3.3 of this document in order to define the nature and extent of the spills in CAU 396. 
7.3 Document the Operational Details and Theoretical Assumptions of the Selected Design in the Sampling and Analysis Plan

Detailed documentation of sampling and analysis is in the main body of this SAFER plan. 


\section{REFERENCES}

DOE/NV, see U.S. Department of Energy, Nevada Operation Office.

EPA, see U.S. Environmental Protection Agency.

FFACO, see Federal Facility Agreement and Consent Order.

Federal Facility Agreement and Consent Order. 1996 (as amended). Agreed to by the State of Nevada, the U.S. Department of Energy, and the U.S. Department of Defense.

McArther, R. D. and Miller, F. L., Jr. 1989. Off-Site Radiation Exposure Review Project (ORERP), Phase II Soil Program, DOE/NV/10384-23. Las Vegas, NV.

NAC, see Nevada Administrative Code.

NNSA/NSO, see U.S. Department of Energy, National Nuclear Security Administration Nevada Site Office.

Nevada Administrative Code. 2002. 445A.2272, "Contamination of Soil: Establishment of Action Levels." Carson City, NV.

Raytheon Services Nevada. 1991. Nevada Test Site Drilling and Mining Summary. Prepared for U.S. Department of Energy, Nevada Operations Office. Las Vegas, NV

Reynolds Electrical and Engineering Co., Inc. 1991. Inventory of Inactive and Abandoned Facilities and Waste Sites Areas 19-20 Volume 4 of 5, Las Vegas, NV

RSN, see Raytheon Services Nevada.

U.S. Department of Energy, Nevada Operations Office. 1988. CERCLA Preliminary Assessment of DOE's Nevada Operations Office Nuclear Weapons Testing Areas, Volume I. Prepared by the Desert Research Institute. Las Vegas, NV: Water Resources Center

U.S. Department of Energy, Nevada Operations Office. 1996. The Final Environmental Impact Statement for the Nevada Test Site and Off-site Locations in the State of Nevada. Las Vegas, NV.

U.S. Department of Energy, Nevada Operations Office. 2000. United States Nuclear Tests July 1945 through September 1992, DOE/NV--209 Rev. 15. Las Vegas, NV.

U.S. Department of Energy, Nevada Operations Office. 2001. Mud Pit Strategy, Nevada Test Site, Nevada, DOE/NV--684. Las Vegas, NV. 
U.S. Department of Energy, National Nuclear Security Administration Nevada Site Office. 2003. Streamlined Approach for Environmental Restoration Plan for Corrective Action Unit 358: Areas 18, 19, 20 Cellars/Mud Pits, Nevada Test Site, Nevada, DOE/NV--837

Rev. 1. Las Vegas, NV.

U.S. Environmental Protection Agency. 1996. Test Methods for Evaluating Solid Waste Physical/Chemical Methods (SW-846) Third Edition. Washington, D.C.

U.S. Environmental Protection Agency. 2000. Guidance for the Data Quality Objective Process, EPA QA/G-4, EPA/600/R-96-055. Washington, D.C.

U.S. Environmental Protection Agency. 2001. Title 40 Code of Federal Regulations 761 , "Polychlorinated Biphenyls (PCBs) Manufacturing, Processing, Distribution in Commerce, and use Prohibitions." Washington, D.C.

U.S. Environmental Protection Agency. 2002. Region IX Preliminary Remediation Goals (PRGs). October. San Francisco, CA. 


\section{APPENDIX B}

\section{CLOSURE CERTIFICATION*}

*Appendix B of the standardized outline for a Federal Facility Agreement and Consent Order Closure Report, Closure Certification, is not required for CAU 396. This appendix is not applicable to CAU 396: Area 20 Spill Sites. 
CLOSURE REPORT - CAU 396

Section: Appendix B

Revision: 0

Date: June 2004

THIS PAGE INTENTIONALLY LEFT BLANK 


\section{APPENDIX C}

\section{AS-BUILT DOCUMENTATION*}

*Appendix C of the standardized outline for a Federal Facility Agreement and Consent Order Closure Report, As-Built Documentation, is not required for CAU 396. This appendix is not applicable to CAU 396: Area 20 Spill Sites. 
CLOSURE REPORT - CAU 396

Section: Appendix C

Revision: 0

Date: June 2004

THIS PAGE INTENTIONALLY LEFT BLANK 
CLOSURE REPORT - CAU 396

Section: Appendix D

Revision: 0

Date: June 2004

\section{APPENDIX D}

\section{SAMPLE ANALYTICAL RESULTS}


CLOSURE REPORT - CAU 396

Section: Appendix D

Revision: 0

Date: June 2004

THIS PAGE INTENTIONALLY LEFT BLANK 
Friday, April 02, 2004

Ted Redding

Bechtel Nevada

P.O. Box 98521 , M/S NTS273

Las Vegas, NV 89193-8521

TEL: 702-295-7220

FAX: (702) 295-3069

RE Project: V2232

Order No.: L0403337

Dear Ted Redding:

NEL Laboratories, Las Vegas received 40 samples on 3/24/04 5:30:00 PM for the analyses presented in the following report.

The case narrative for the project listed above specifies all quality assurance deficiencies associated with the data. Data that is not qualified in the case narrative has met or exceeded the US-EPA or laboratory specifications for the analytical method.

If you have any questions regarding these tests results, please feel free to call.

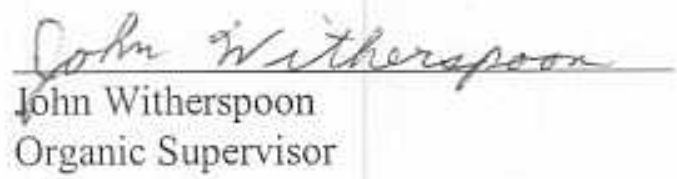

$\frac{4-2-0 y}{\text { Date }}$

Certifications:

Washington

C 325

Idaho NV052

Nevada

NV052

California 2002 
CLIENT:

Project: Bechtel Nevada

Lab Order:

\section{CASE NARRATIVE}

Date: $02-A p r-04$

Attached are the analytical results for samples in support of the above referenced project.

The samples submitted for this project were not sampled by NEL. Should you have any questions or comments, please feel free to contact our Client Services Department.

Analytical Comments:

SW846 8015B Mod.

F3: Hydrocarbons eluted within the Diesel Range (C12-C22). However, the hydrocarbon pattern is atypical of diesel. 


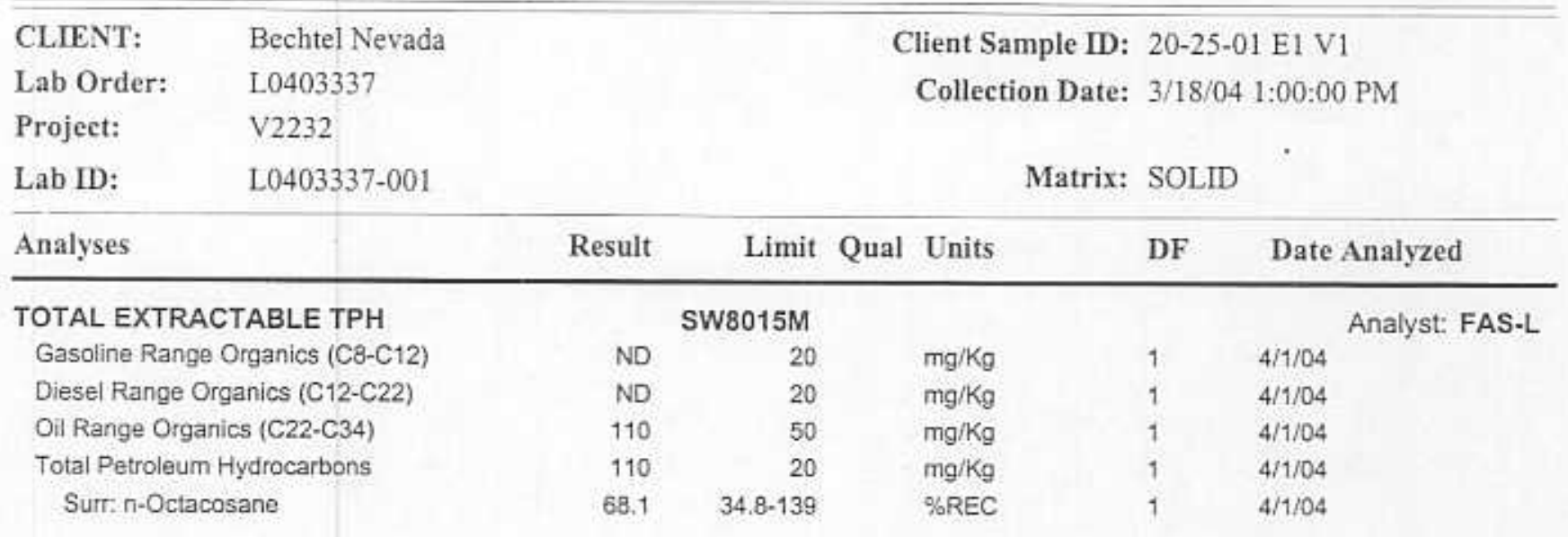

- Value exceeds Maximum Contaminant Levet
S-Spike Recovery outside accepted recovery limits

R-RPD outside accepted recovery limits

E-Value above quantitation range 
NEL Laboratories, Las Vegas

Date: 02-Apr-04

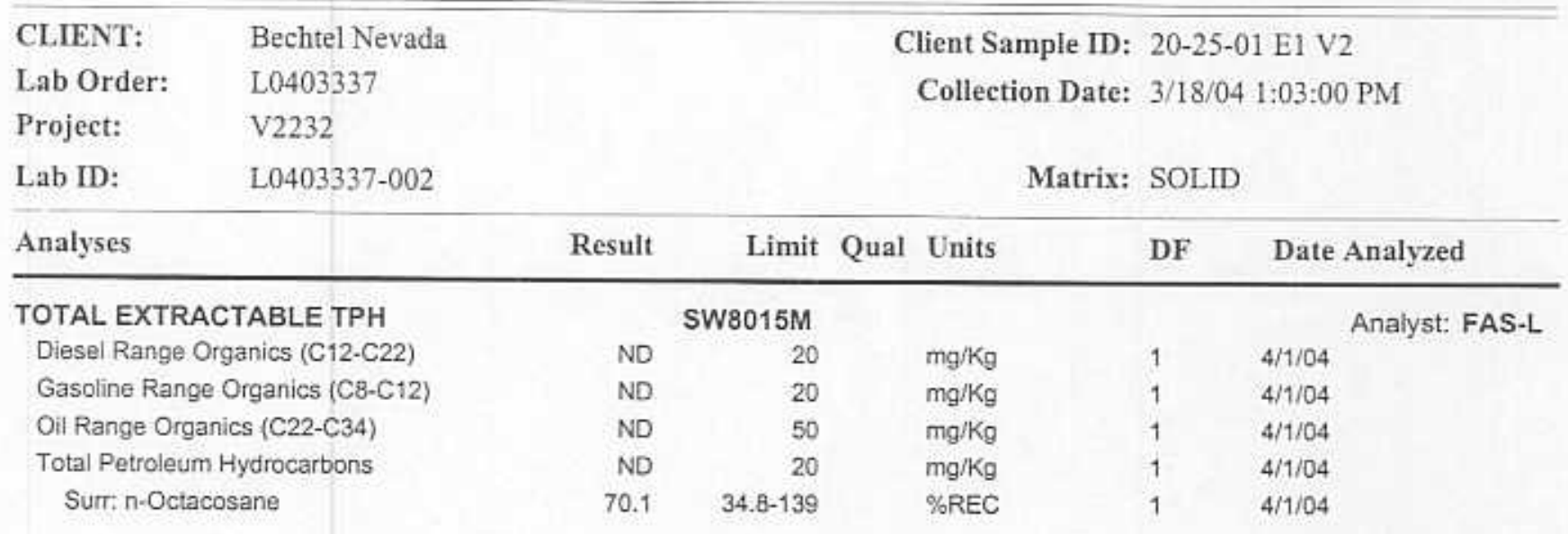

Qualifiers: $\quad$ ND - Not Detected at the Reporting Limit

J- Analyte detected below quanititation limits

B - Analyte detected in the associated Method Blank

- Value exceeds Maximum Contaminant Level
S - Spike Recovery outside accepted recovery limits

R - RPD outside accepted recovery limits

E-Valuc above quantitation range

Page 2 of 40 


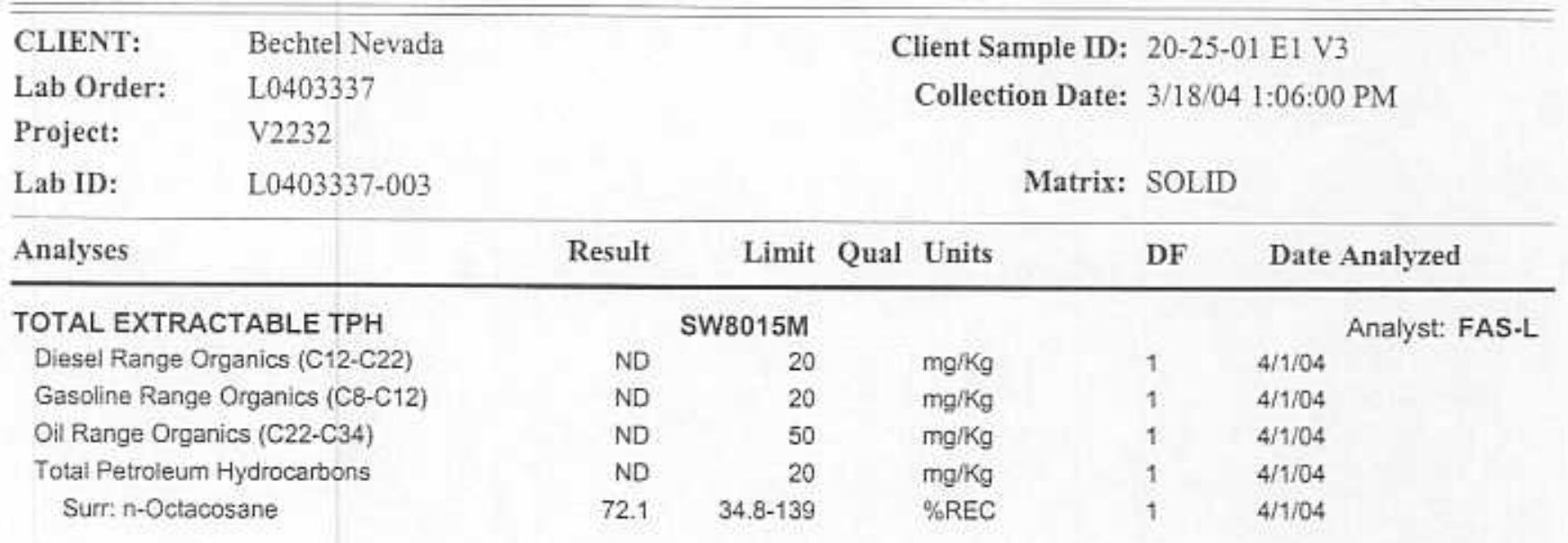

S - Spike Recovery outside accepted recovery limits

R-RPD outside accepted recovery limits

E-Valuc above qutintitation range

Page 3 of 40 


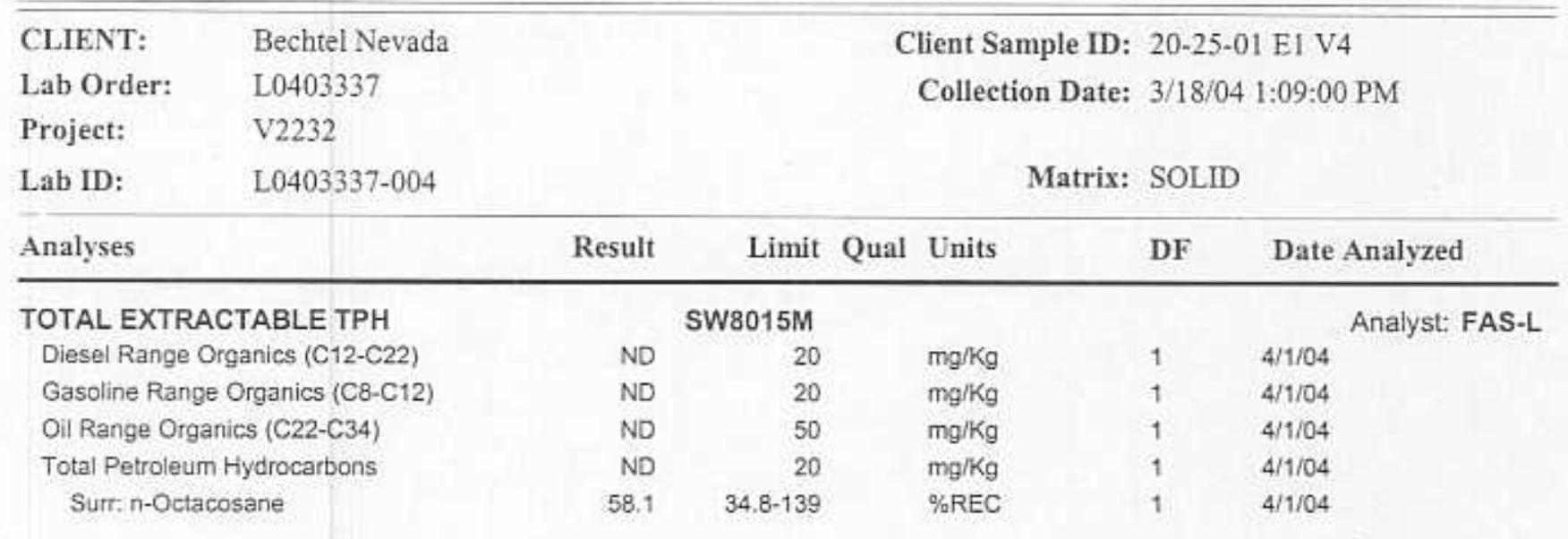

B - Analyte detected in the associated Method Blank

* - Value exceeds Maximum Contaminant Level
S - Spike Recovery outside accepted recovery limits

R-RPD outside accepted recovery limits

E. Value above quantitation range

Page 4 of 40 
NEL Laboratories, Las Vegas

Date: $02-A p r-04$

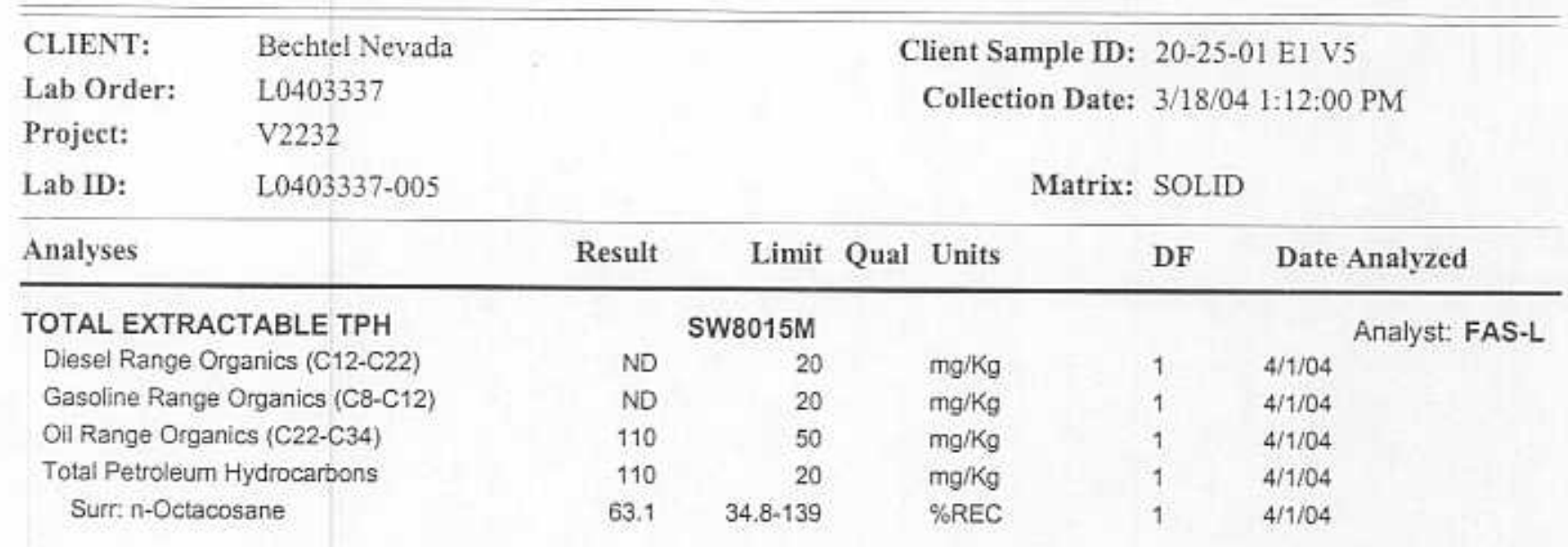

\begin{tabular}{|c|c|c|}
\hline \multirow[t]{3}{*}{ Qualifiers: } & ND- Not Detected at the Reporting Limit & S-Spike Recovery outside accepted recovery limits \\
\hline & $\mathrm{J}$ - Analyte detected below quanititation limits & R-RPD outside accepted recovery limits \\
\hline & B - Analyte detected in the associated Method Blank & E-Value above quantitation range \\
\hline
\end{tabular}

- Value exceeds Maximum Contaminant Level

Page 5 of 40 
NEL Laboratories, Las Vegas

Date: $02-A p r-04$

\begin{tabular}{|c|c|c|c|c|c|c|c|}
\hline CLIENT: & Bechtel Nevada & \multicolumn{6}{|c|}{ Client Sample ID: $20-25-01$ E2 V1 } \\
\hline Lab Order: & L0403337 & \multirow{2}{*}{\multicolumn{4}{|c|}{ Collection Date: }} & \multicolumn{2}{|c|}{ 3/18/04 1:15:00 PM } \\
\hline Project: & V2232 & & & & & & \\
\hline Lab ID: & L0403337-006 & \multicolumn{4}{|r|}{ Matrix: } & \multicolumn{2}{|l|}{ SOLID } \\
\hline \multicolumn{2}{|l|}{ Analyses } & Result & Limit & Qual & Units & DF & Date Analyzed \\
\hline \multirow{2}{*}{\multicolumn{2}{|c|}{$\begin{array}{l}\text { TOTAL EXTRACTABLE TPH } \\
\text { Diesel Range Organics (C12-C22) }\end{array}$}} & \multicolumn{3}{|c|}{ SW8015M } & & \multicolumn{2}{|r|}{ Analyst: FAS-L } \\
\hline & & ND & 20 & & $\mathrm{mg} / \mathrm{Kg}$ & 1 & $3 / 31 / 04$ \\
\hline \multicolumn{2}{|c|}{ Gasoline Range Organics (C8-C12) } & ND & 20 & & $\mathrm{mg} / \mathrm{Kg}$ & 1 & $3 / 31 / 04$ \\
\hline \multicolumn{2}{|c|}{ Oil Range Organics (C22-C34) } & ND & 50 & & $\mathrm{mg} / \mathrm{Kg}$ & 1 & $3 / 31 / 04$ \\
\hline \multicolumn{2}{|c|}{ Total Petroleum Hydrocarbons } & ND & 20 & & $\mathrm{mg} / \mathrm{Kg}$ & 1 & $3 / 31 / 04$ \\
\hline \multicolumn{2}{|c|}{ Surr: n-Octacosane } & 63.1 & $34.8-139$ & & \%REC & 1 & $3 / 31 / 04$ \\
\hline
\end{tabular}

Qualifiers: ND - Not Detected at the Reporting Limit

J.-Aralyte detected below quarititation limits

B - Analyte detected in the associated Method Blank

* Value exceeds Maximum Contaminant Level
S - Spike Recovery outside accepted recovery limits

R-RPD outside accepted recovery limits

E - Value above quantitation range

Page 6 of 40 


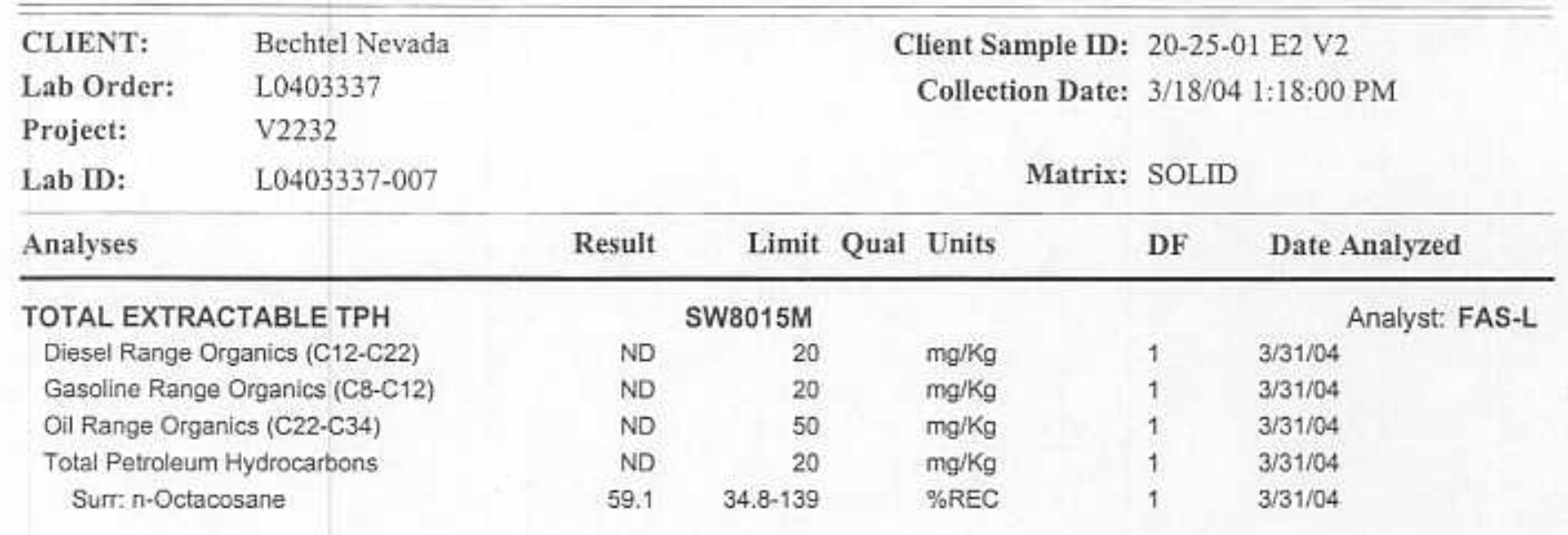

Qualifiers: ND - Not Detected at the Reporting Limit

I - Analyte detected below quanititation limits

B - Analyte detected in the associated Method Blank

*-Value exceeds Maximum Contaminant Level
S - Spike Recovery outside aecepted recovery limits

R-RPD outside accepted recovery limits

$\mathrm{E}$ - Value above quantitation range

Page 7 of 40 
NEL Laboratories, Las Vegas

Date: $02-A p r-04$

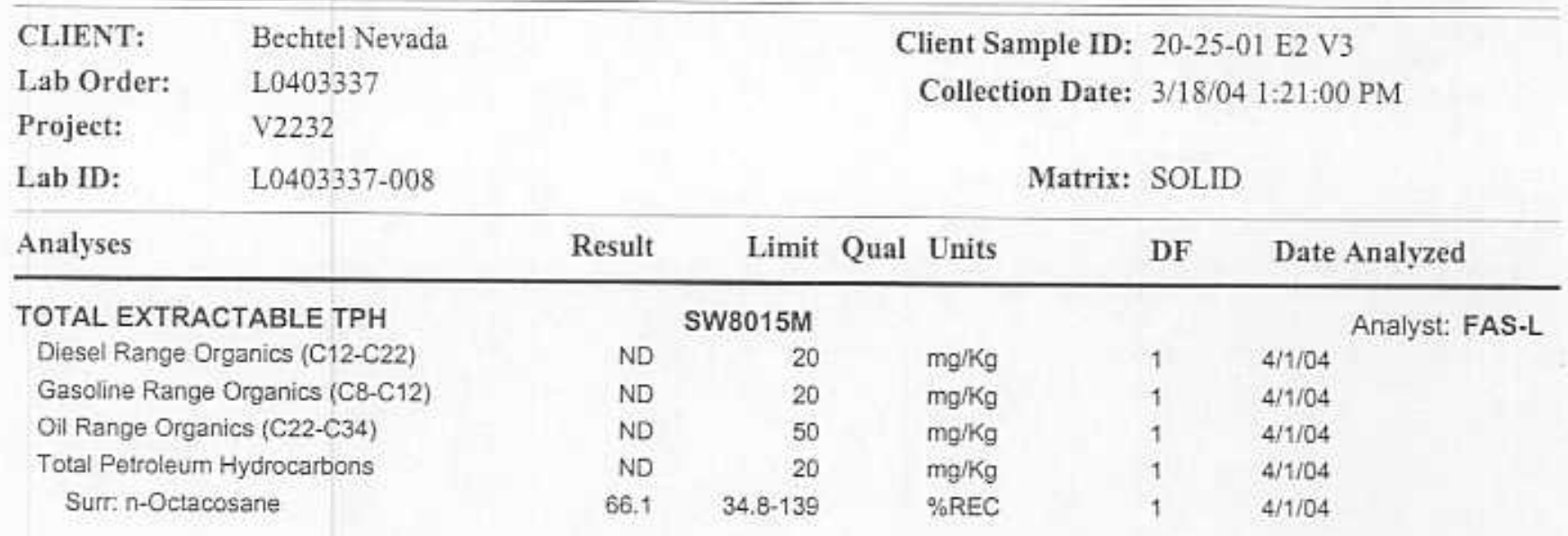

Qualifiers: ND - Not Detected at the Reporting Limit

$\mathrm{J}$ - Analyte detected below quanititation limits

B - Analyte detected in the associated Method Blank

- Value exceeds Maximum Contaminant Level
S - Spike Recovery outside accepted recovery limits

R - RPD outside accepted recovery limits

E - Value above quantitation range

Page 8 of 40 


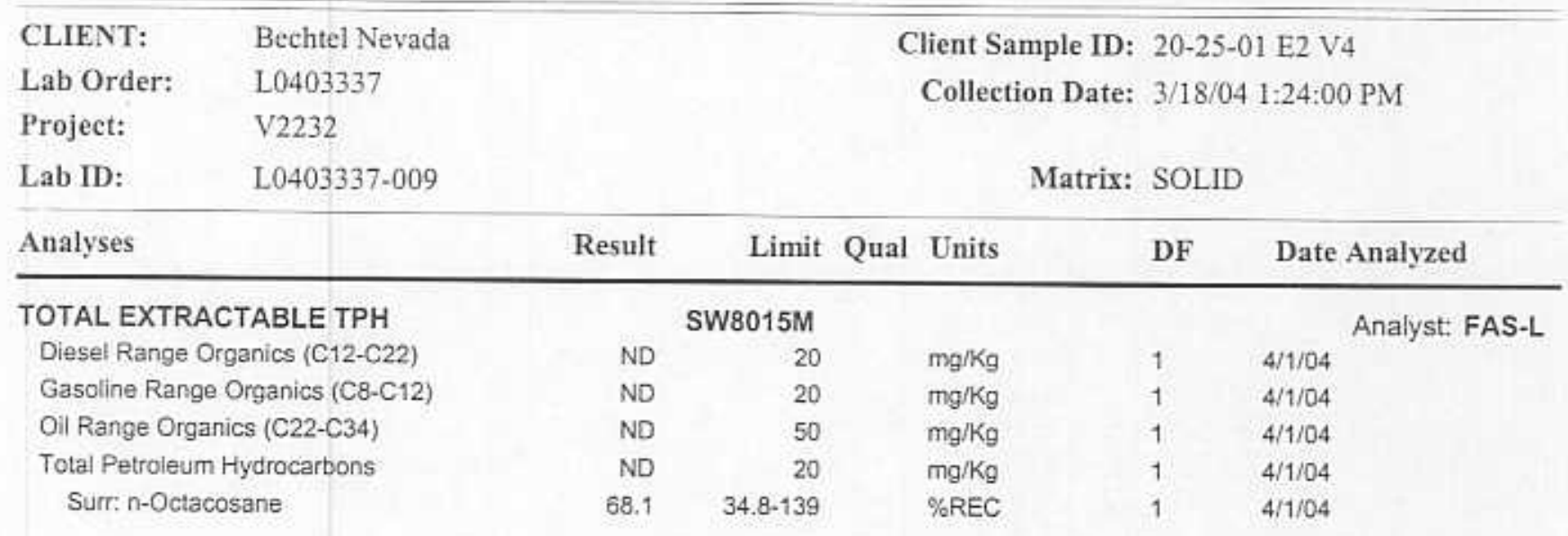

$\begin{array}{lll}\text { Qualifiers: } & \text { ND - Not Detected at the Reporting Limit } & \text { S - Spike Recovery outside accepted recovery limits } \\ \text { J-Analyte detected below quarititation limits } & \text { R - RPD outside accepted recovery limits } \\ \text { B-Analyte detected in the associated Method Blank } & \text { E - Value above quantitation range }\end{array}$

\footnotetext{
- Value exceeds Maximum Contaminant Level
} 
NEL Laboratories, Las Vegas

Date: 02-Apr-04

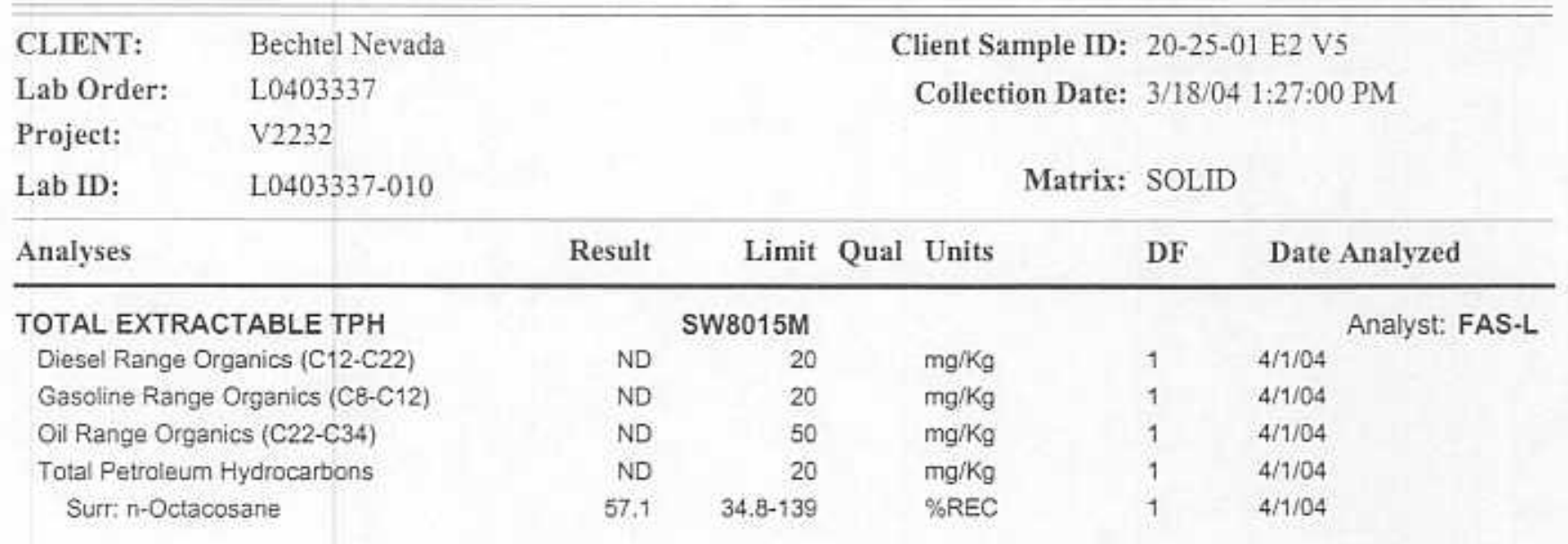

Qualifiers: $\quad$ ND - Not Detected at the Reporting Limit

J - Analyte detected below quanititation limits

B - Analyte detected in the associated Method Blank

- Value exceeds Maximum Contaminant Level
S - Spike Recovery outside accepted recovery limits

R - RPD outside accepted recovery limits

E- Value above quantitation range

Page 10 of 40 
NEL Laboratories, Las Vegas

Date: $02 \backsim A p r-04$

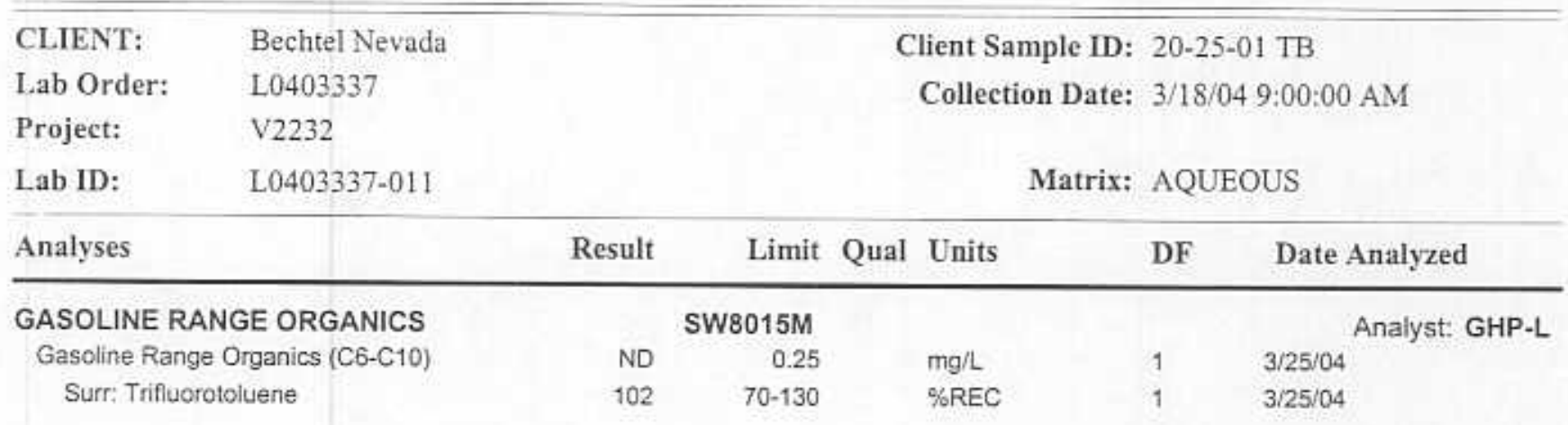

Qualifiers: ND - Not Detected at the Reporting Limit

J - Analyte detected below quanititation limits

B - Analyte detected in the associated Method Blank

- Value exceeds Maximum Contaminant Level
S - Spike Recovery outside accepted recovery limits

R-RPD outside accepted recovery limits

$\mathrm{E}$ - Value above quantitation range

Page 11 of 40 
NEL Laboratories, Las Vegas

Date: 02-Apr-04

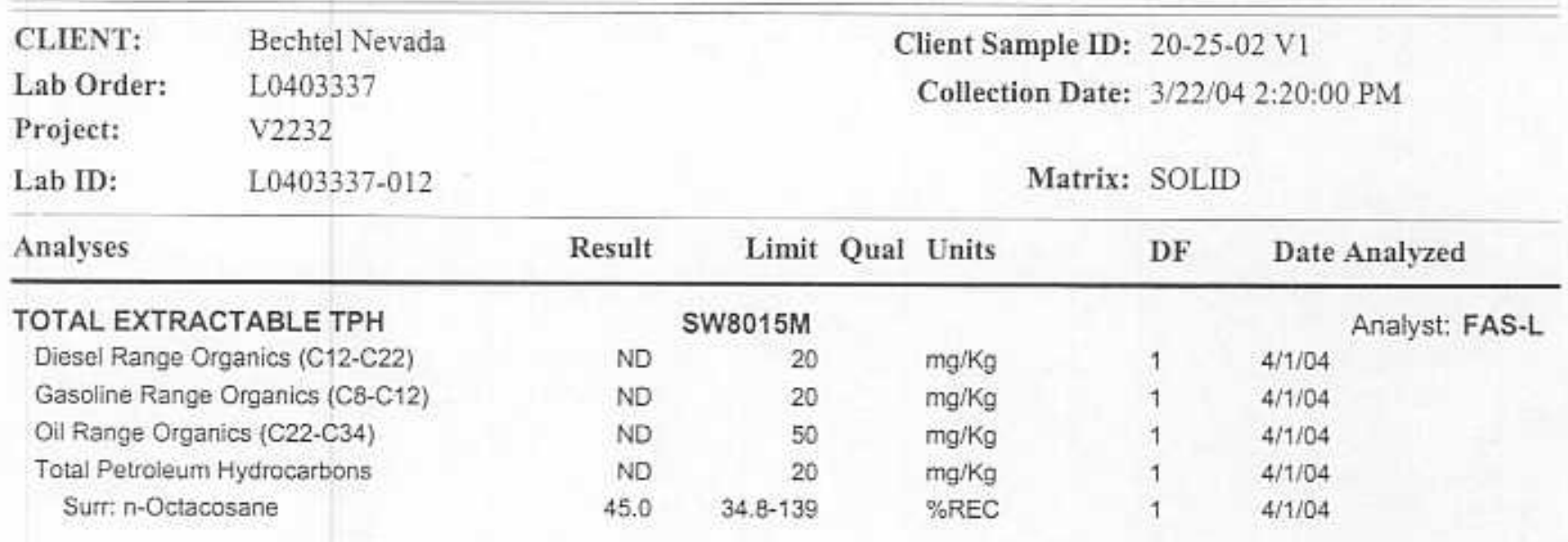

Qualifiers: ND - Not Detected at the Reporting Limit

J - Analyte detected below quanititation limits

B - Analyte detected in the associated Method Blank

* - Value exceeds Maximum Contaminant Level
S - Spike Recovery outside accepted recovery limits

R - RPD outside accepted recovery limits

$\mathrm{E}$ - Value above quantitation range

Page 12 of 40 
NEL Laboratories, Las Vegas

Date: $02-A p r-04$

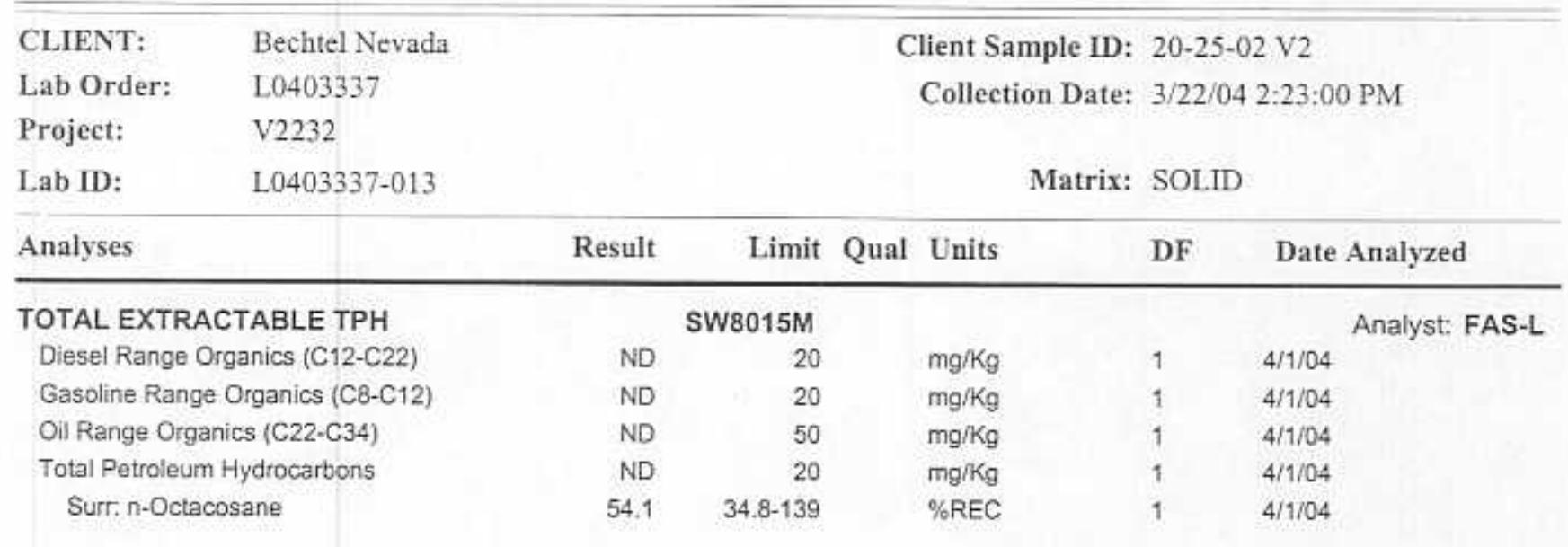

\begin{tabular}{|c|c|c|}
\hline \multirow[t]{3}{*}{ Qualifiers: } & ND - Not Detected at the Reporting Limit & S - Spike Recovery outside accepted recovery limits \\
\hline & I- Analyle detected below quanititation limits & R - RPD outside accepted recovery limits \\
\hline & B - Analyte detected in the associated Method Blank & E - Value ubove quantitation range \\
\hline
\end{tabular}

- Value exceeds Maximum Contaminant Level 
NEL Laboratories, Las Vegas

Date: $02-A p r-04$

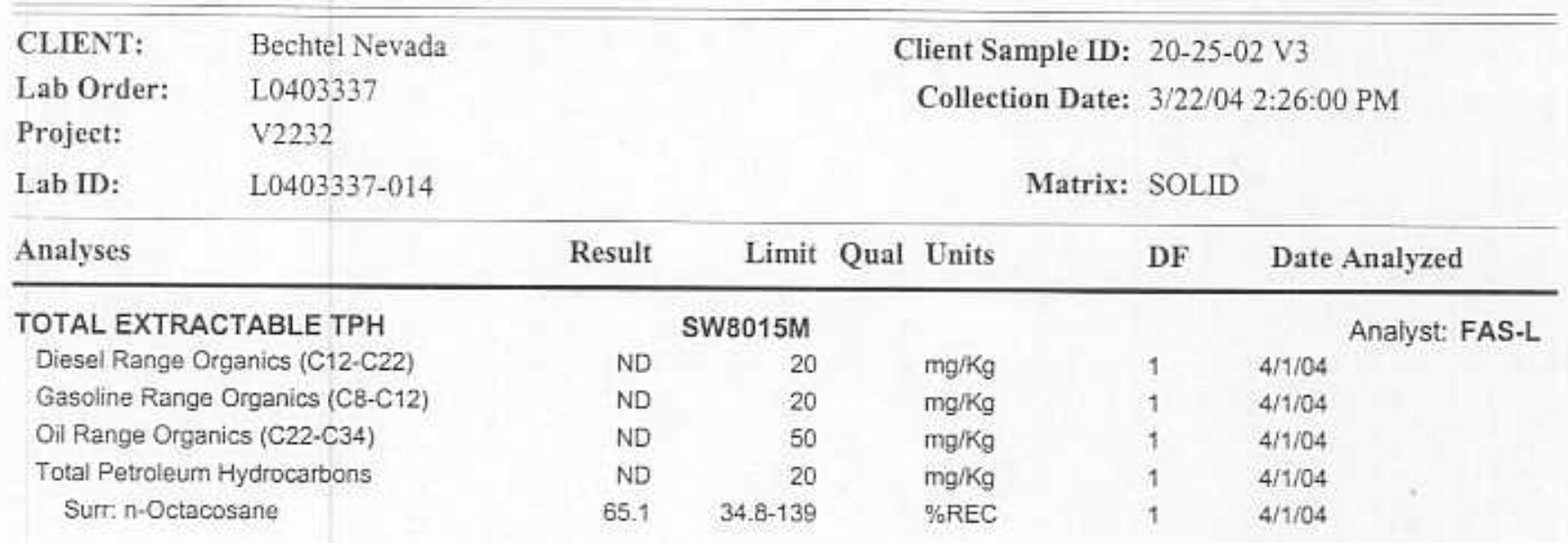

Qualifiers: ND - Not Detected at the Reporting Limit

J - Analyte detected below quanititation limits

B - Analyte detected in the associated Method Blank

- Value exceeds Maximum Contaminant Level
S - Spike Recovery outside accepted recovery limits

R - RPD outside accepted recovery limits

$E$ - Value above quantitation range

Page 14 of 40 
NEL Laboratories, Las Vegas

Date: 02-Apr-04

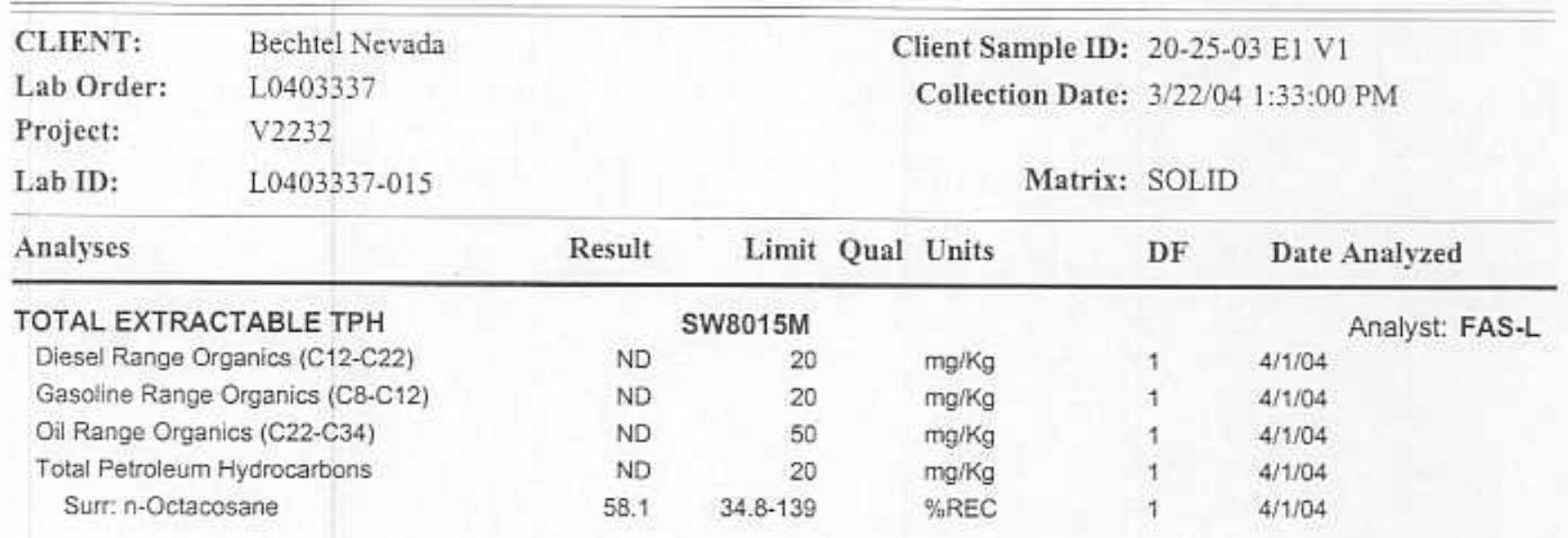

S - Spike Recovery outside accepted recovery limits

R - RPD autside accepted recovery limits

E-Value above quantitation range 
NEL Laboratories, Las Vegas

Date: 02-Apr-04

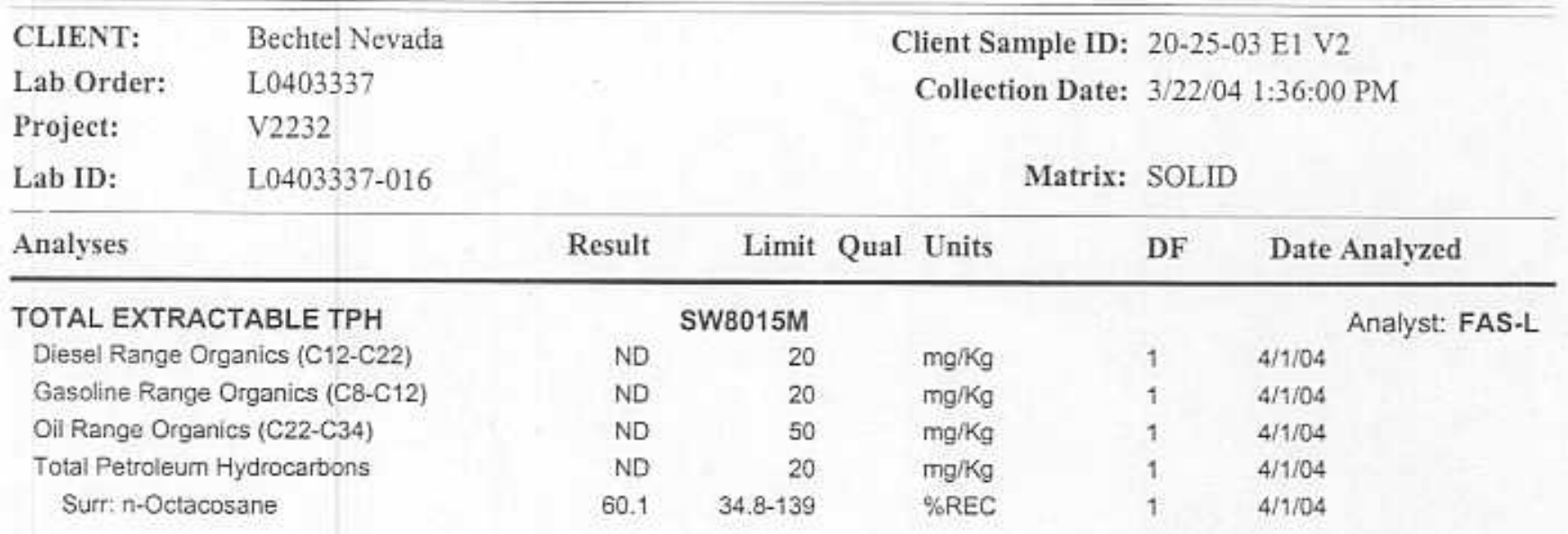

Qualifiers: ND - Not Detected at the Reporting Limit

J - Analyte detected below quanititation limits

B - Analyte detected in the associated Method Blank

* - Value exceeds Maximum Contaminant Level
S - Spike Recovery outside accepted recovery limits

R - RPD outside accepted recovery limits

E-Value above quantitation range

Page 16 of 40 
NEL Laboratories, Las Vegas

Date: 02-Apr-04

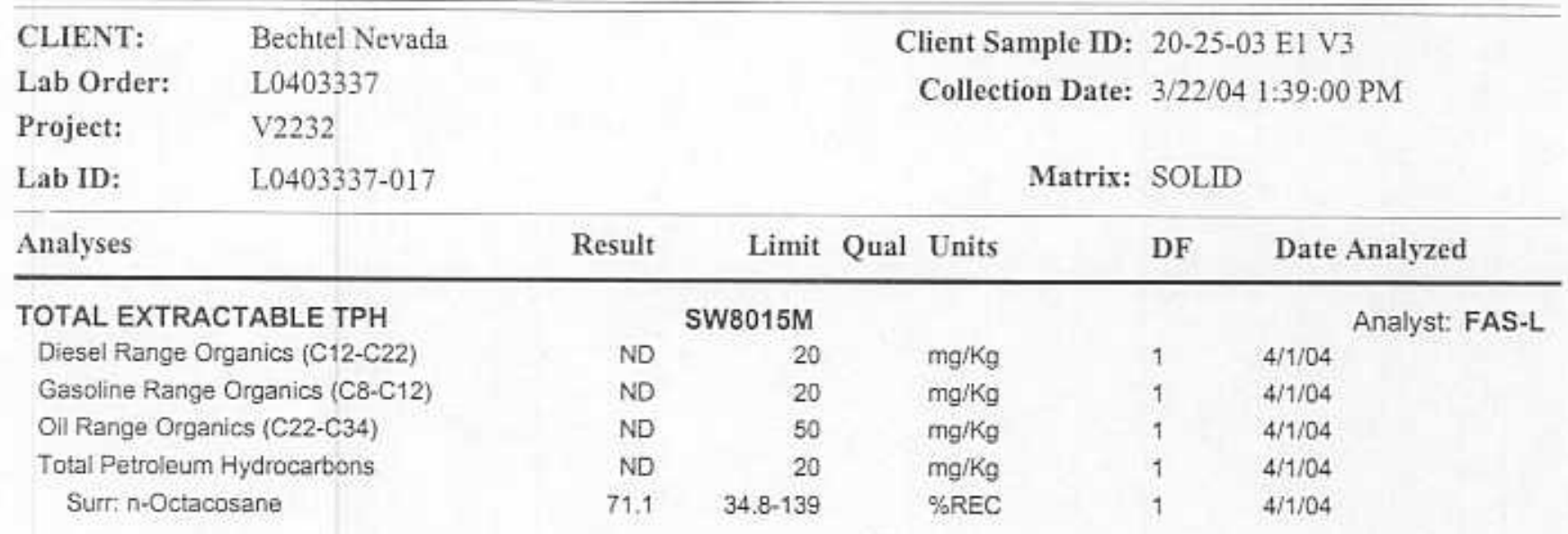

Qualifiers: ND - Not Detected at the Reporting Limit

J-Analyte detected below quarititation limits

B - Analyte detected in the associated Method Blank

- Value exceeds Maximum Contaminant Level
S - Spike Recovery outside accepted recovery limits

R-RPD outside accepted recovery limits

$\mathrm{E}$ - Value above quantitation range

Page 17 of 40 
NEL Laboratories, Las Vegas

Date: 02-Apr-04

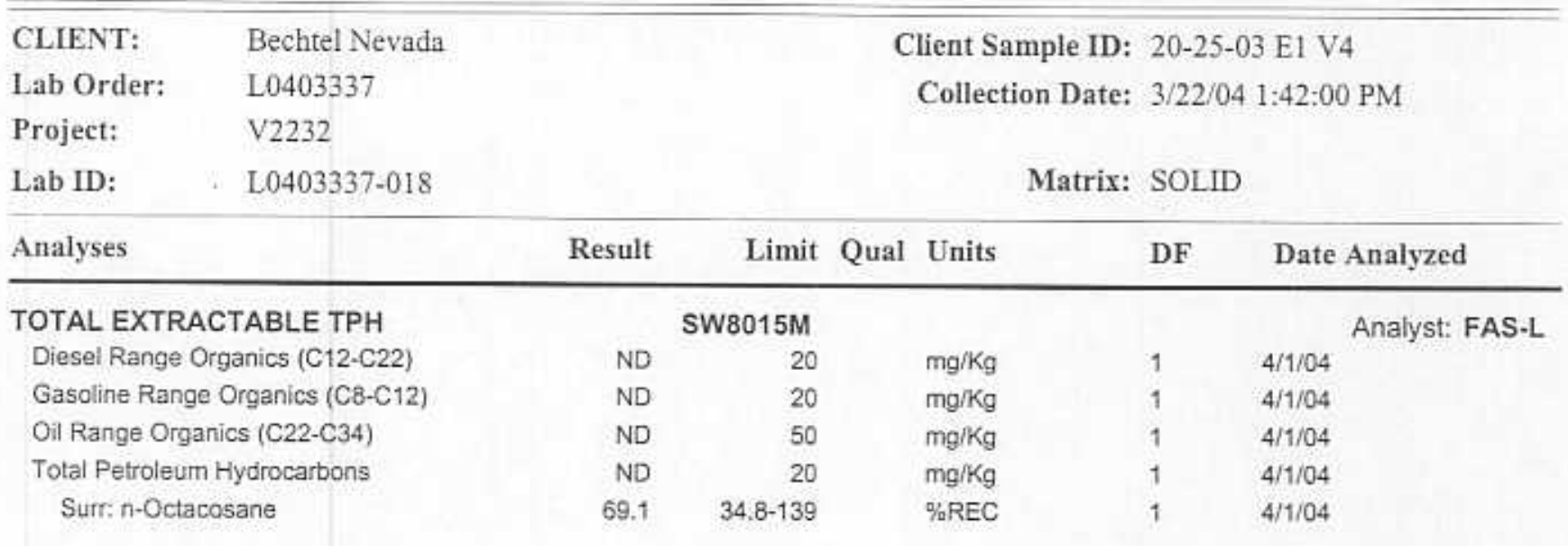

Qualifiers: ND - Not Detected at the Reporting Limit

J-Analyte detected below quanititation limits

B - Analyte detected in the associated Method Blank

- - Value exceeds Maximum Contaminant Level
S - Spike Recovery outside accepted recovery limits

R-RPD outside accepted recovery limits

$\mathrm{E}$ - Value above quantitation range 
NEL Laboratories, Las Vegas

Date: $02-A p r-04$

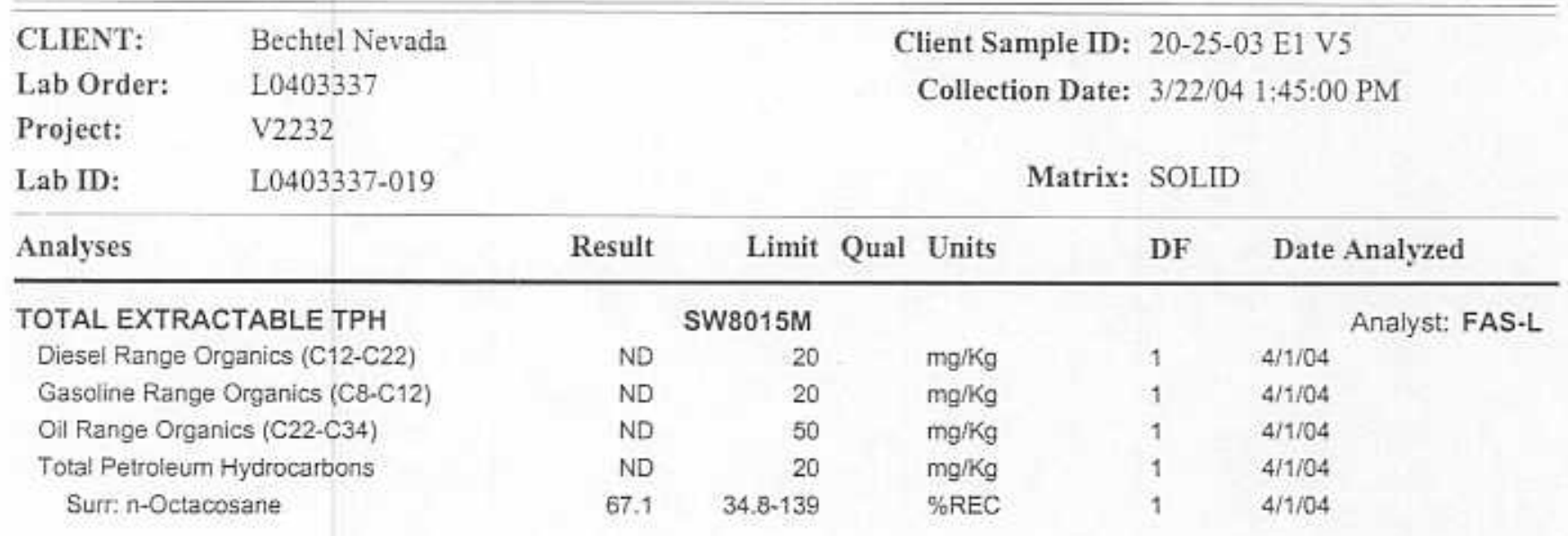

Qualifiers: ND - Not Detected at the Reporting Limit

J - Analyte detected below quanititation limits

B - Arralyte detected in the associated Method Blank

* - Value exceeds Maximum Contaminant Level
S - Spike Recovery outside accepted recovery limits

R - RPD outside accepted recovery limits

E - Value above quantitation range

Page 19 of 40 
NEL Laboratories, Las Vegas

Date: $02-A p r-04$

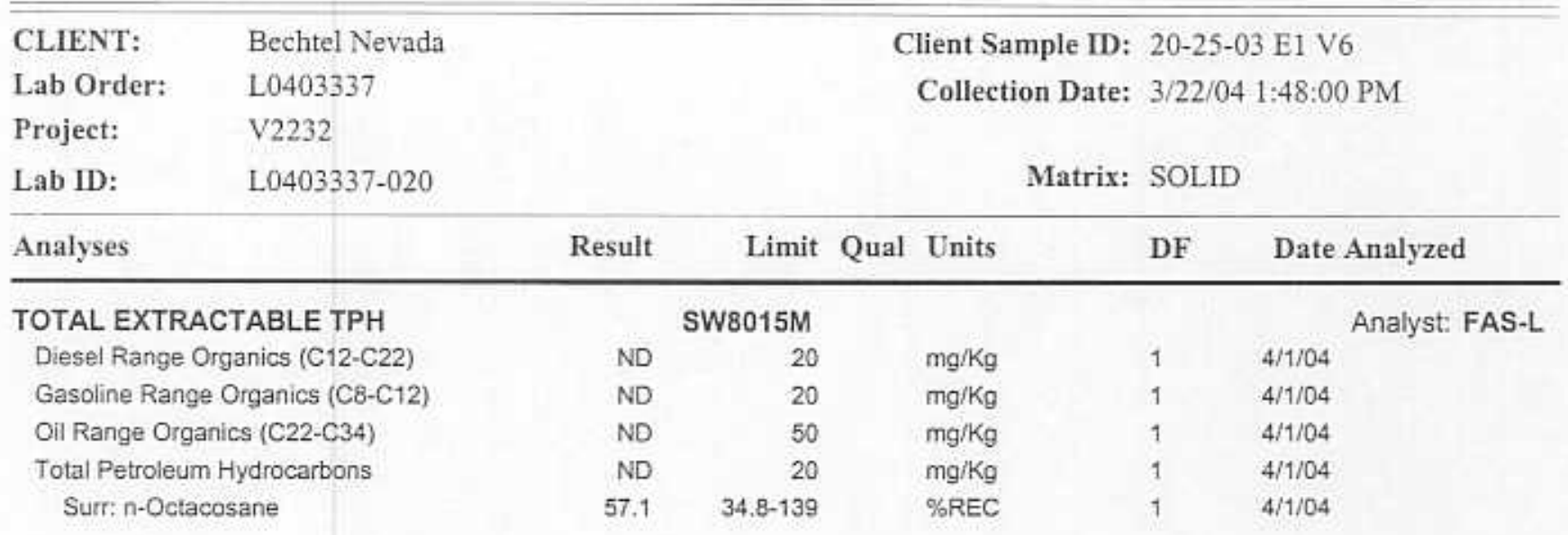

Qualifiers: ND - Not Detected at the Reporting Limit

J - Analyte detected below quanititation limits

B - Analyte detected in the associated Method Blank

* - Value exceeds Maximum Contaminant Level
S - Spike Recovery outside accepted recovery limits

R - RPD outside accepted recovery limits

E-Value above quantitation range

Page 20 of 40 
NEL Laboratories, Las Vegas

Date: $02-A p r-04$

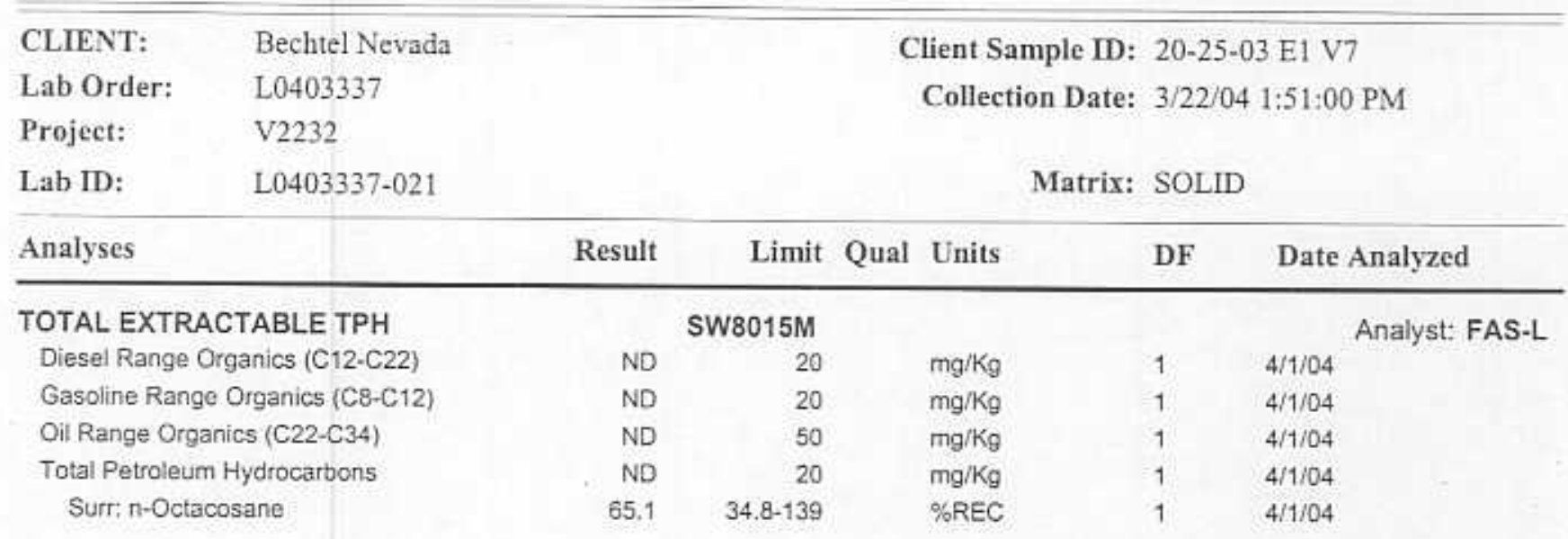

Qualifiers: ND - Not Detected at the Reporting Limit

J-Analyte detected below quanititation limits

B - Analyte detected in the associated Method Blank.

- Value exceeds Maximum Contaminant Level
S - Spike Recovery outside accepted recovery limits

R-RPD outside accepted recovery limits

E-Value above quantitation range

Page 21 of 40 
NEL Laboratories, Las Vegas

CLIENT:

Lab Order: $\quad$ L0403337

Project: V2232

Lab ID: $\quad$ L.0403337-022
Date: $12-4 p r-1|d|$

Client Sample ID: $20-25-03$ EI V8

Collection Date: 3,22,04 1,54:00 PM

Matrix: SOL.1D

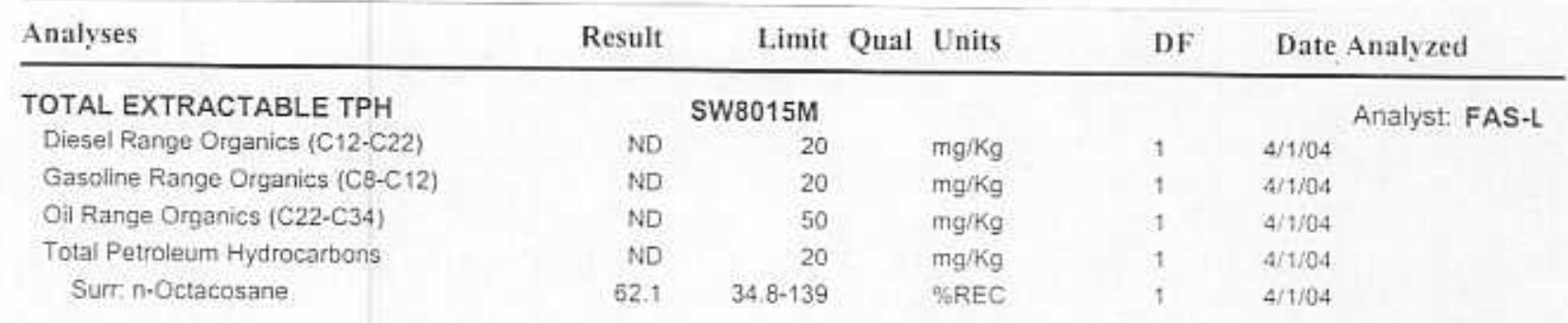

Qualifiers:

ND - Not Detected at the Reporting Limit

I- Analyte detected below quanititation limits

B- Analye detected in the associated Methed Blank

- Value exceeds Maximum Contaminant Level
S. Spike Recovery outside accepted recovery limits

R - RPD outside accepted recavery limits

E- Value above quantitation range

Page 22 of 40 
NEL Laboratories, Las Vegas

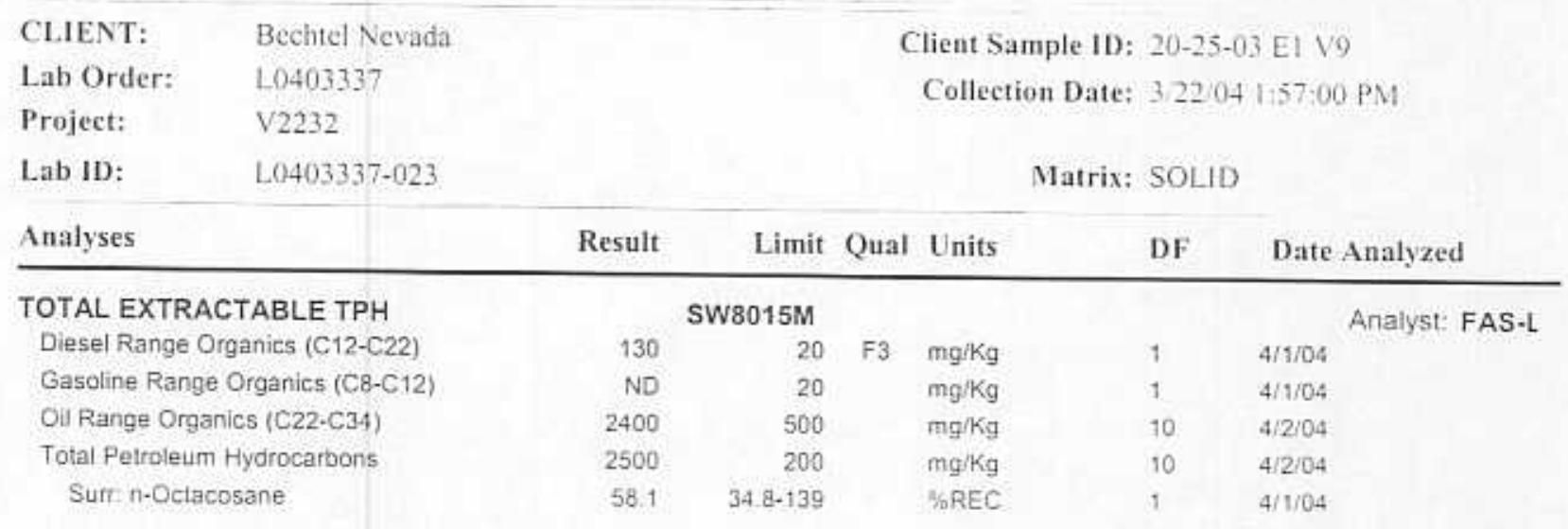

Date: $02-\lambda p r-(04$

Cient Sample 1D: 20-25-03 EI V9

Matrix: SOLID
Qualifiers: ND-Not Detected at the Reporting Limit

1-Analyte detected below quantitation limits

B-Analye detected in the associated Method Blank

- Value exceeds Maximum Contaminant Level 
NEL Laboratories, Las Vegas

CLIENT: Bechtel Nevada

Lab Order: $\quad$ L0403337

Project: V2232

Lab ID: $\quad$ L0403337-024

\begin{tabular}{|c|c|c|c|c|c|c|}
\hline Analyses & Result & Limit & Qual & Units & DF & Date Analyzed \\
\hline \multirow{2}{*}{$\begin{array}{l}\text { GASOLINE RANGE ORGANICS } \\
\text { Gasoline Range Organics (C6-C10) }\end{array}$} & & $3015 \mathrm{M}$ & & & & Analyst: GHP-I \\
\hline & NO & 0.25 & & $\mathrm{mg} / \mathrm{L}$ & 1 & $3 / 25 / 04$ \\
\hline Surr: Trifluorotoluene & 103 & $70-130$ & & $\% R E C$ & 1 & $3 / 25 / 04$ \\
\hline
\end{tabular}

Client Sample ID: 20-25-03 TB

Collection Date: 32204 9:00:00 AM

Matrix: AOUEOUS 


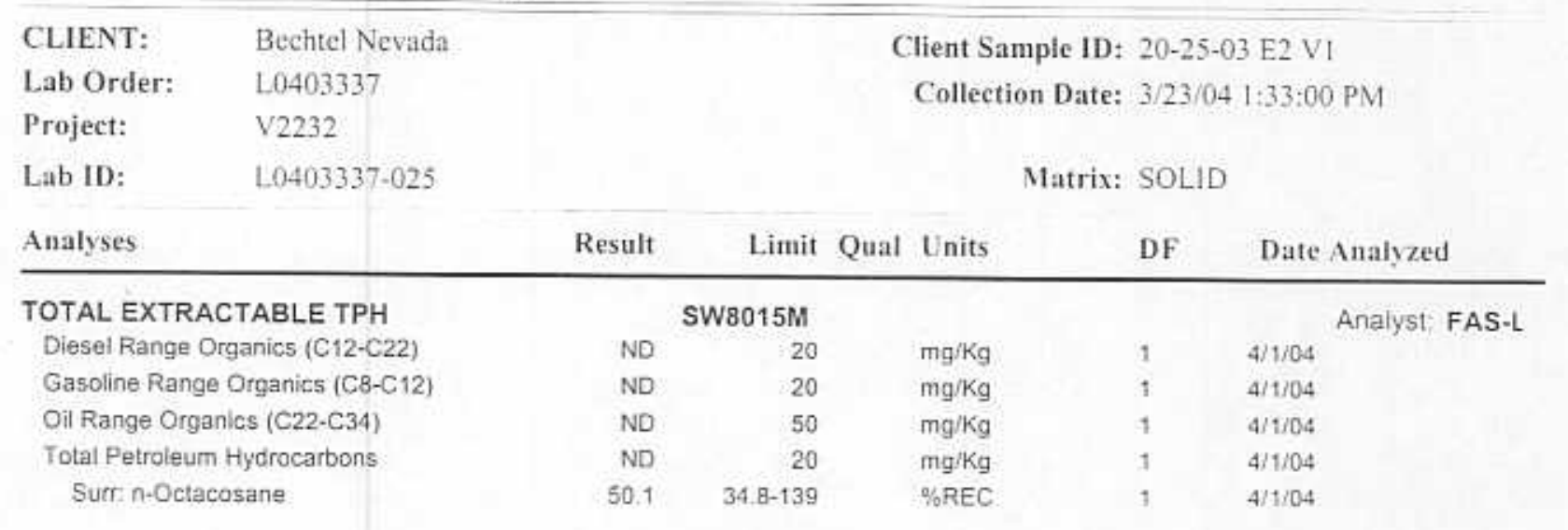

Qualifiters: ND - Not Detected at the Reporting Limit

1-Amalye derected below quamititaion limits

B - Anafute delected in the associated Method Blank

- Value exceeds Maximum Contaminant Lavel
S- Spike Recovery outside accepted recovery limits

R - RPD outside accepred recovery limits

E - Value above quantiation range

Page 25 of 40 
NEL Laboratories, Las Vegas

Date: $02-A p r-04$

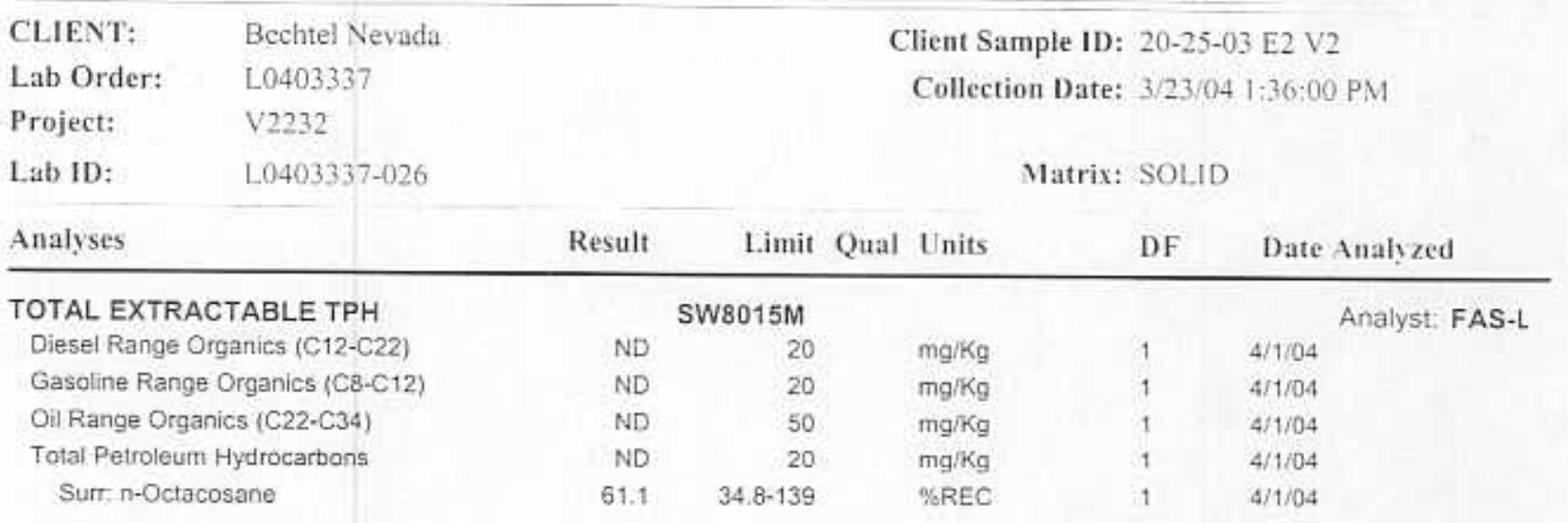

Qualifiers: ND - Not Detected at the Repoining Limit

J- Analyte desected beiow quartitation limits

B - Analye detected in the associated Method Blank

- Value exceeds Maximum Contaminant Level
S- Spike Recovery outside accepted recovery limits

R-RPD outside accepted recovery limits

E- Value above quantization range

Page 26 of 40 
NEL Laboratories, Las Vegas

Date: $02-A p r-04$

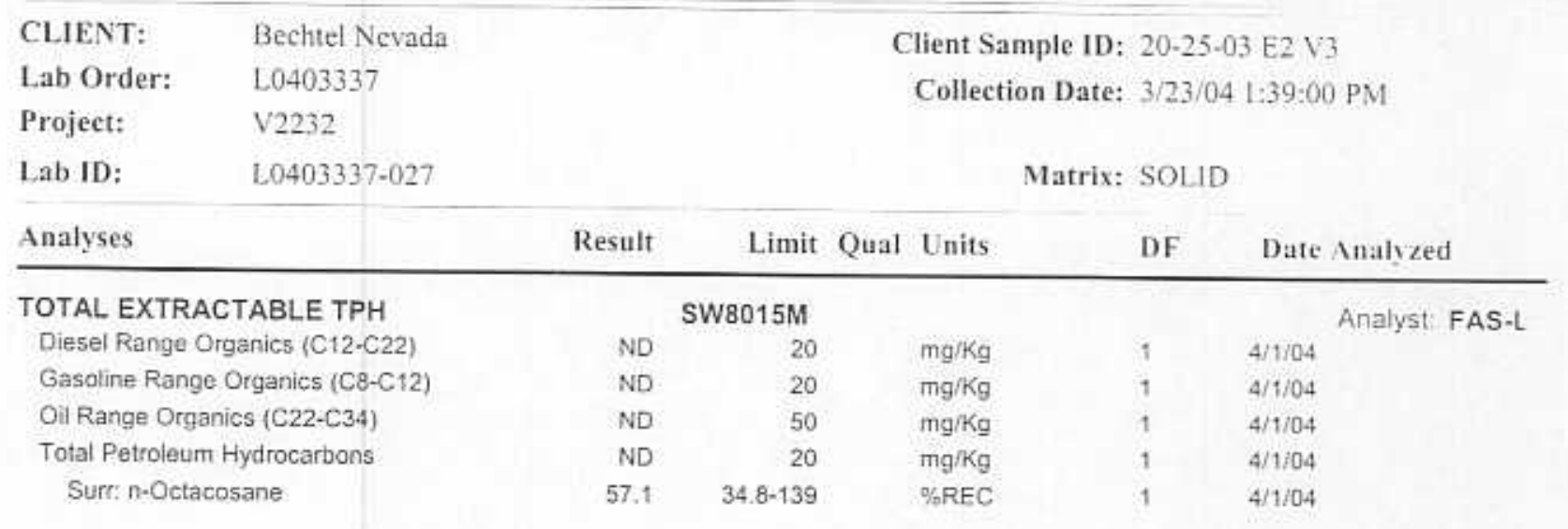

Qualifiers:

ND - Not Detected at the Reporting Limis

1. Analyte derected telow quarnitiation limits

B - Analyte delected in the associated Method Blank

* Valuc exceeds Maximum Contamurant Level
S - Spike Recovery cutside accepted recovery limits

$R-R P D$ outside aceepted recovery limits.

E-Value above quantitation range

Page 27 of 40 
NEL Laboratories, Las Vegas

Date: $02-4 p r-01+$

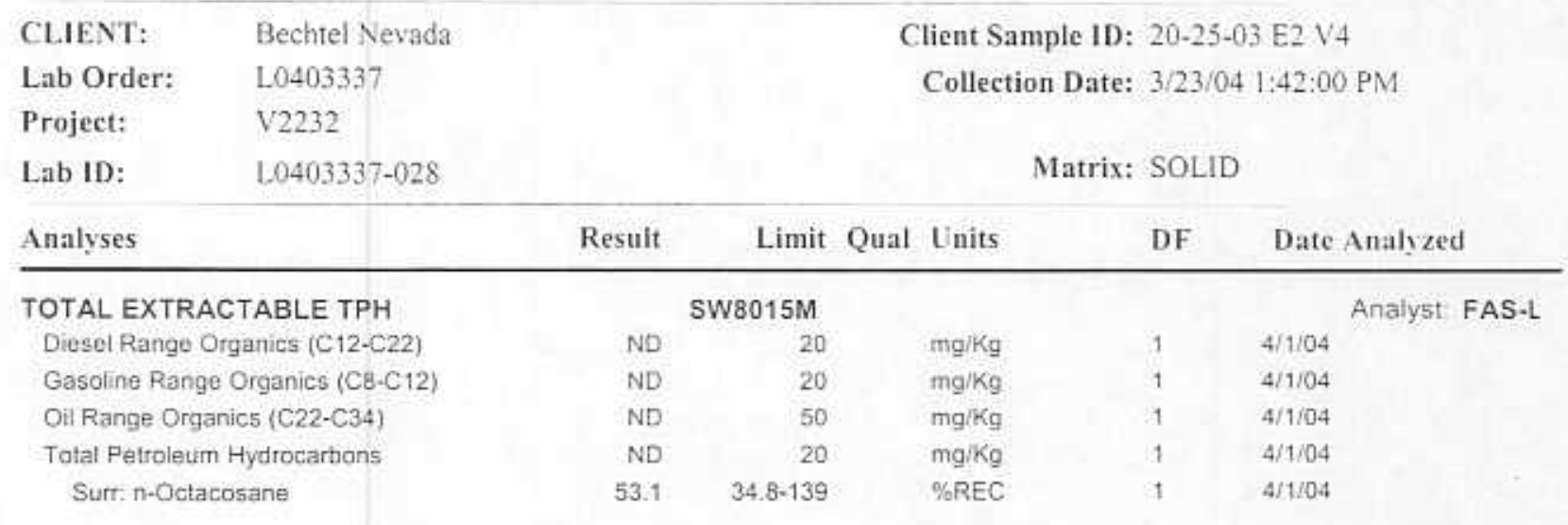

Qualifiers:

ND - Not Detected at the Reporting Limit

3-Analyte detected below quanitutation limirs

B - Amalyte defected in the associated Method Blank

- Value exceeds Maximum Contaminans Level
S-Spike Recovery outside accepted recovery limits

R - RPD outside acespted fecovery limits

E- Value above quantitation range

Page 28 of 40 
NEL Laboratories, Las Vegas

Date: $02-A p r-04$

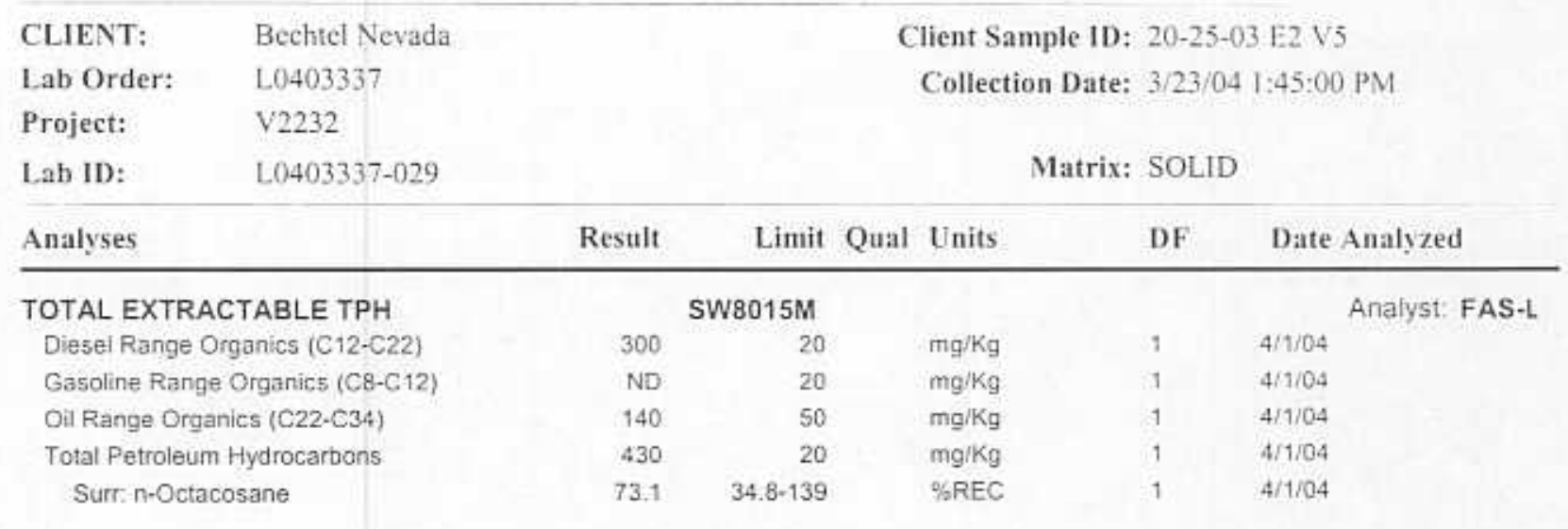

Qualifiers:

ND - Not Detected at the Reporting Limit

J-Analye detected below quanititation limits

B. Analyte detected in the associated Method Blank

* Value exceeds Maximum Contaminant Level
S. Spike Recovery outside aceepted recovery limits

R - RPD outside aceopted recovery limits.

E - Value above quantitation range

Page 29 of 40 
NEL Laboratories, Las Vegas

Lab Order: L0403337

Project: V2232

Lab ID: $\quad$ L0403337-030

\begin{tabular}{|c|c|c|c|c|c|c|c|}
\hline Analyses & Result & Limit & Qual & Units & DF & Date & Analyzed \\
\hline TOTAL EXTRACTABLE TPH & \multicolumn{3}{|c|}{ SW8015M } & & & & \multirow[t]{6}{*}{ Analyst: FAS-L } \\
\hline Diesel Range Organics (C12-C22) & ND & 20 & & $\mathrm{mg} / \mathrm{kg}$ & 1 & $4 / 1 / 04$ & \\
\hline Gasoline Range Organics (C8-C12) & ND & 20 & & $\mathrm{mg} / \mathrm{Kg}$ & 1 & $4 / 1 / 04$ & \\
\hline Oil Range Organics (C22-C34) & ND & 50 & & $m g / K g$ & 1 & $4 / 1 / 04$ & \\
\hline Total Petroleum Hydrocarbons & ND & 20 & & $\mathrm{mg} / \mathrm{kg}$ & 1 & $4 / 1 / 04$ & \\
\hline Surr: n-Octacosane & 581 & $34.8 \cdot 139$ & & PGEC & 1 & $4 / 1 / 04$ & \\
\hline
\end{tabular}

Client Sample ID: 20-25-03 E2 V6

Collection Date: $3 / 23 / 04$ 1:48:00 PM

Matrix: SOLID

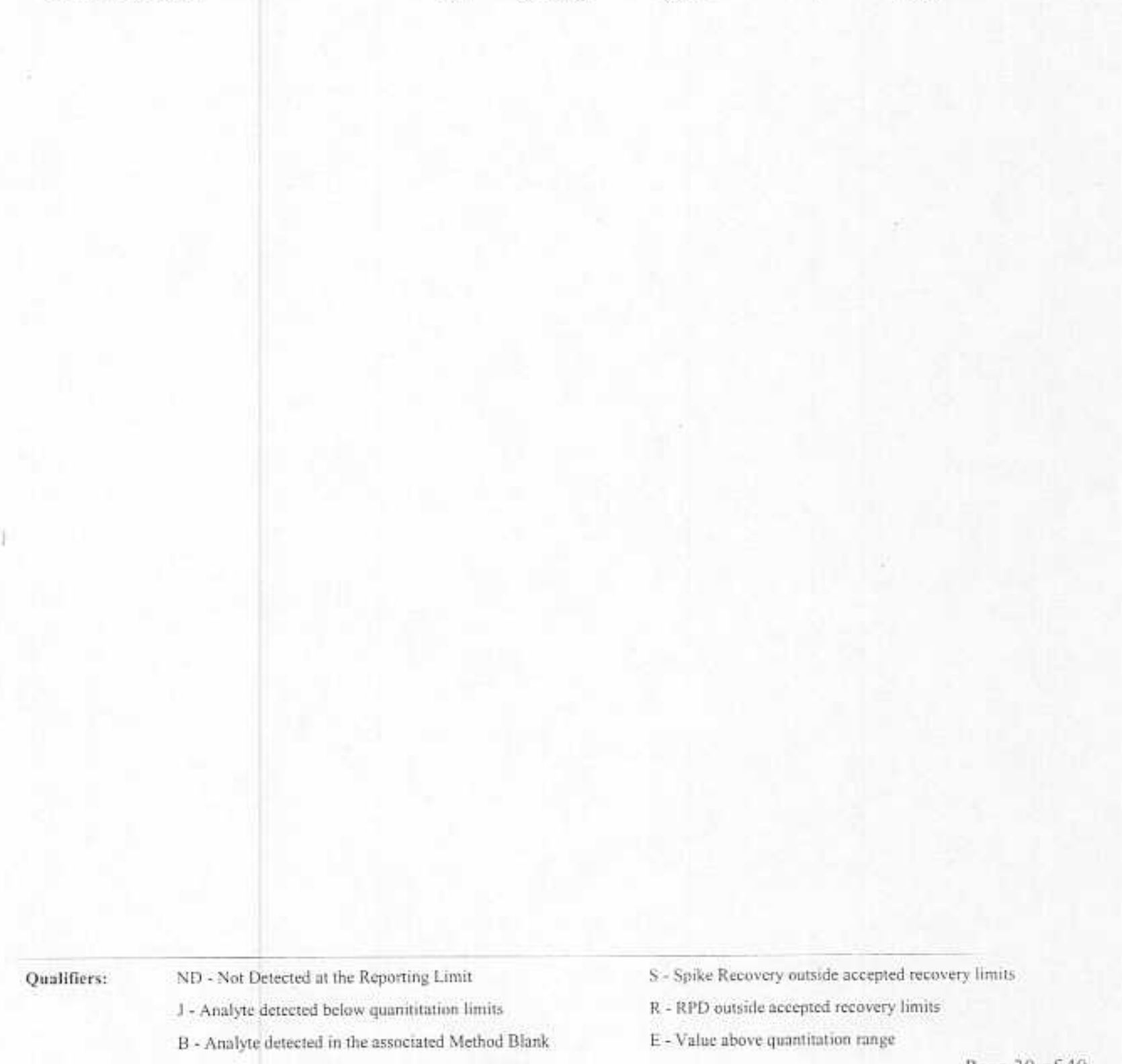

- Value exceeds Maximum Contaminant Level 
NEL Laboratories, Las Vegas

CLIENT: Bechtel Nevada

Lab Order: $\quad$ L0403337

Project: V2232

Lab ID: L0403337-031
Date: $02-4 p r-04$

Client Sample 1D: 20-25-03 E2 V7

Collection Date: $3 / 23 / 04$ 1:51:00 PM

Matrix: SOLID

\begin{tabular}{|c|c|c|c|c|c|c|}
\hline Analyses & Result & Limit & Qual & Units & DF & Date Analyzed \\
\hline TOTAL EXTRACTABLE TPH & & $18015 \mathrm{M}$ & & & & Analyst: FAS-L \\
\hline Diessel Range Organics (C12-C22) & ND & 20 & & $\mathrm{mg} / \mathrm{kg}$ & 1 & 4/1/04 \\
\hline Gasoline Range Organics (C8-C12) & ND & 20 & & $\mathrm{mg} / \mathrm{kg}$ & 1 & 4/1/04 \\
\hline Oil Range Organics (C22-C34) & ND & 50 & & $\mathrm{mg} / \mathrm{kg}$ & 1 & 4/1/04 \\
\hline Total Petroleum Hydrocarbons & ND & 20 & & mg/kg & 1 & 4/1/04 \\
\hline Surr: n-Octacosane & 59.1 & $34.8-139$ & & $\%$ REC & 1 & 4/1/04 \\
\hline
\end{tabular}

Qualifiers: ND - Not Detected at the Reporing Limit

J. Analyte detected below quanititation limits

B - Analyte detecled in the assaciated Method Blank

* Value exceeds Maximum Contaminant Level
S - Spike Recovery outside accepted recovery limuts

R - RPD outside accepted tecovery limits

E-Value above quantitation range

Page 31 of 40 
Date: $02-4 p r-04$

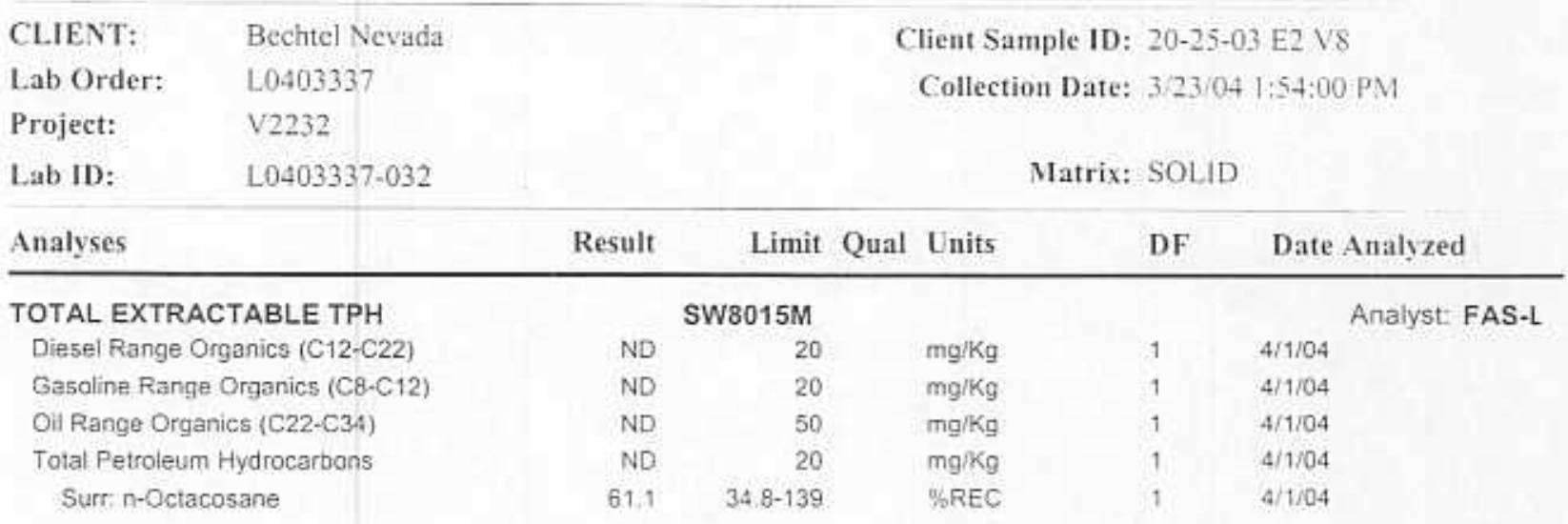

J-Analyte detected below quanititation limits

B-Analyte detected in the associated Method Blank

- Value exceets Maximum Comaminant Level
S- Spike Recovery outside aceepted recovery lumits

R - RPD outside accepted recovery limits

E-Value above quantitation range 


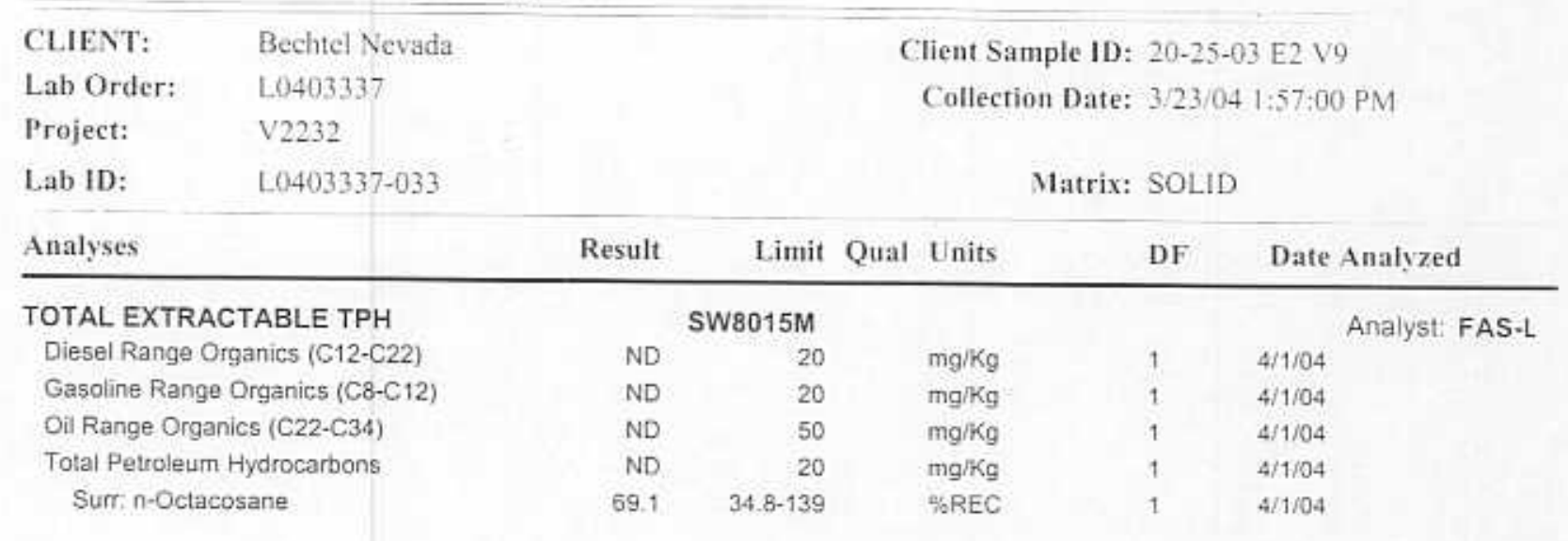

S - Spise Recovery outside actepted recovery hmits

R - RPD outside accepted recovery limiss

E- Value floove quantitation range

Page 33 of 40 
NEL Laboratories, Las Vegas

Date: $02-A p r-0+4$

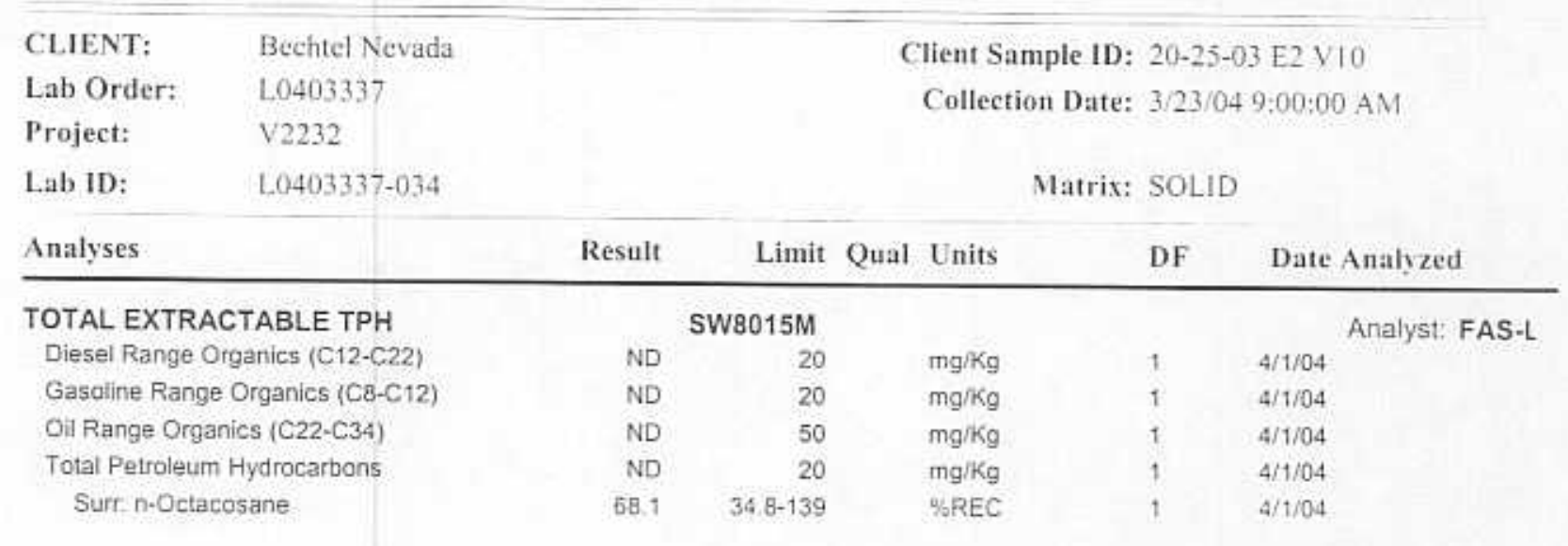

\section{Qualifiers:}

ND - Not Detected at the Rcporning Limit

J - Analyte detected below quanitiation limits

B. Analye defected in the associated Method Blank

- Value exceeds Maximum Contaminant Level
S. Spike Recovery ourside accepted recovery limits

R-RPD outside accepted recovery limits

E. Value ahove quantitation range

Puge 34 of 40 
Date: $02-A p r-04$

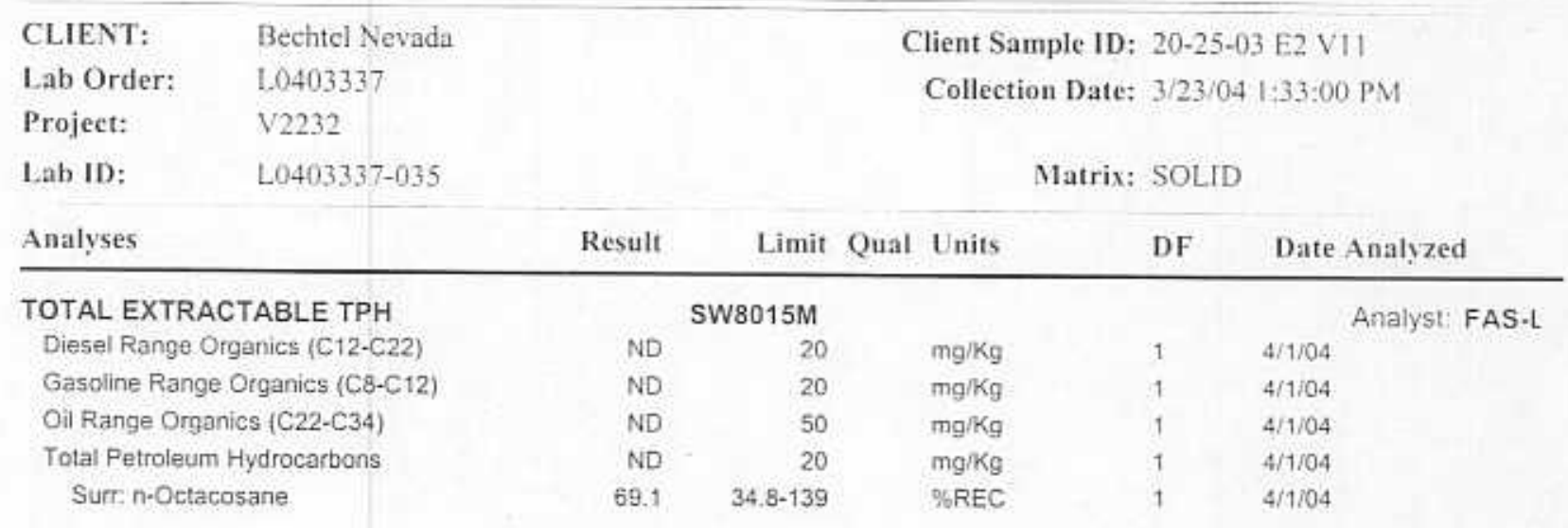

Qualifiers: ND - Not Detected at the Reporting Limit

1. Analyte detected below quanititation limits

B - Analyte detected in the associaled Method Biani

- Value exceeds Maximum Contaminant Level
S- Spike Recovery outside accepted recovery limits

R - RPD outside accepted tecovery limits

E - Value above quantitation range

Page 35 of 40 
Date: $02-4 p r-04$

\begin{tabular}{|c|c|c|c|c|c|c|c|c|}
\hline $\begin{array}{l}\text { CLIENT: } \\
\text { Lab Order: }\end{array}$ & $\begin{array}{l}\text { Bechtel Nevada } \\
\text { L0403337 }\end{array}$ & \multicolumn{7}{|c|}{ Client Sample ID: $20-25-03$ E2 V12 } \\
\hline Lab ID: & L0403337-036 & \multicolumn{6}{|c|}{ Matrix: SOLID } & \multirow[b]{2}{*}{ e Analyzed } \\
\hline Analyses & & Result & Limit & Qual & Units & DF & Date , & \\
\hline \multirow{2}{*}{\multicolumn{2}{|c|}{$\begin{array}{l}\text { TOTAL EXTRACTABLE TPH } \\
\text { Diesel Range Organics (C12-C22) }\end{array}$}} & & V8015M & & & & & \multirow{6}{*}{ Analyst } \\
\hline & & ND & 20 & & $\mathrm{mg} / \mathrm{Kg}$ & 1 & $4 / 1 / 04$ & \\
\hline \multirow{2}{*}{\multicolumn{2}{|c|}{$\begin{array}{l}\text { Gasoline Range Organics (C8-C12) } \\
\text { Oil Range Organics }(\mathrm{C} 22 \cdot \mathrm{C} 34)\end{array}$}} & ND & 20 & & $\mathrm{mg} / \mathrm{Kg}$ & 1 & $4 / 1 / 04$ & \\
\hline & & ND & 50 & & $\mathrm{mg} / \mathrm{Kg}$ & 1 & 4/1/04 & \\
\hline \multirow{2}{*}{\multicolumn{2}{|c|}{$\begin{array}{l}\text { Total Petroleum Hydrocarbons } \\
\text { Surr n-Octacosane }\end{array}$}} & ND & 20 & & $\mathrm{mg} / \mathrm{Kg}$ & 1 & $4 / 1 / 04$ & \\
\hline & & 70.1 & $34.8-139$ & & $\%$ REC & 1 & $4 / 1 / 04$ & \\
\hline
\end{tabular}

Qualifiers: ND - Not Detected at the Reporting Limit

1-Analyte defected below qquanititation limits

B - Analyte detected in the associated Method Blank.

- Value exceeds Maximum Contaminant Level
S - Spike Reeovery outside accepted recovery limus

$R$ - RPD outside accepted recovery limits

E-Value above quantitation range

Page 36 of 40 
NEL Laboratories, Las Vegas

Date: $02-4 p r-1)-1$

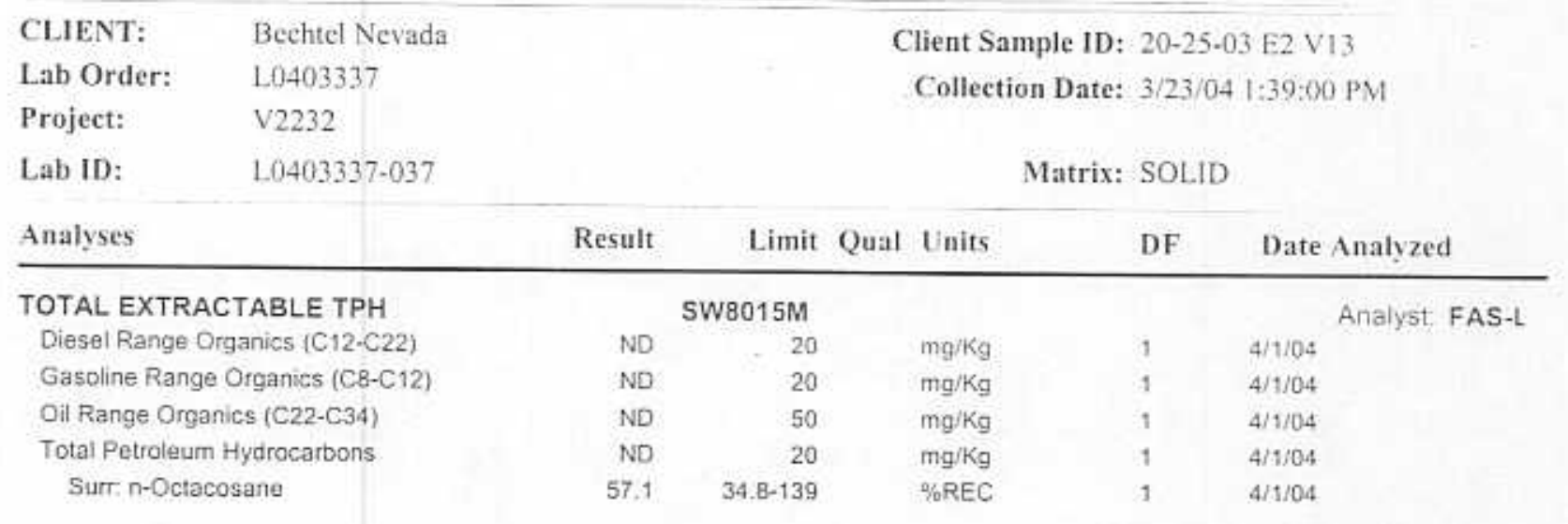

Qualifiers: ND - Not Detected at the Reporting Limit

f-Analyse defected below quanititation limits

B. Analve detected in the associated Method Blank

*. Value exceeds Maximum Contamimant Level
S- Spike Recovery outside accepted recovery limits

R - RPD outside accepted recovery limits

E-Value above quantitation ranye

Page 37 of 40 
Date: $02-4 p r-0)+$

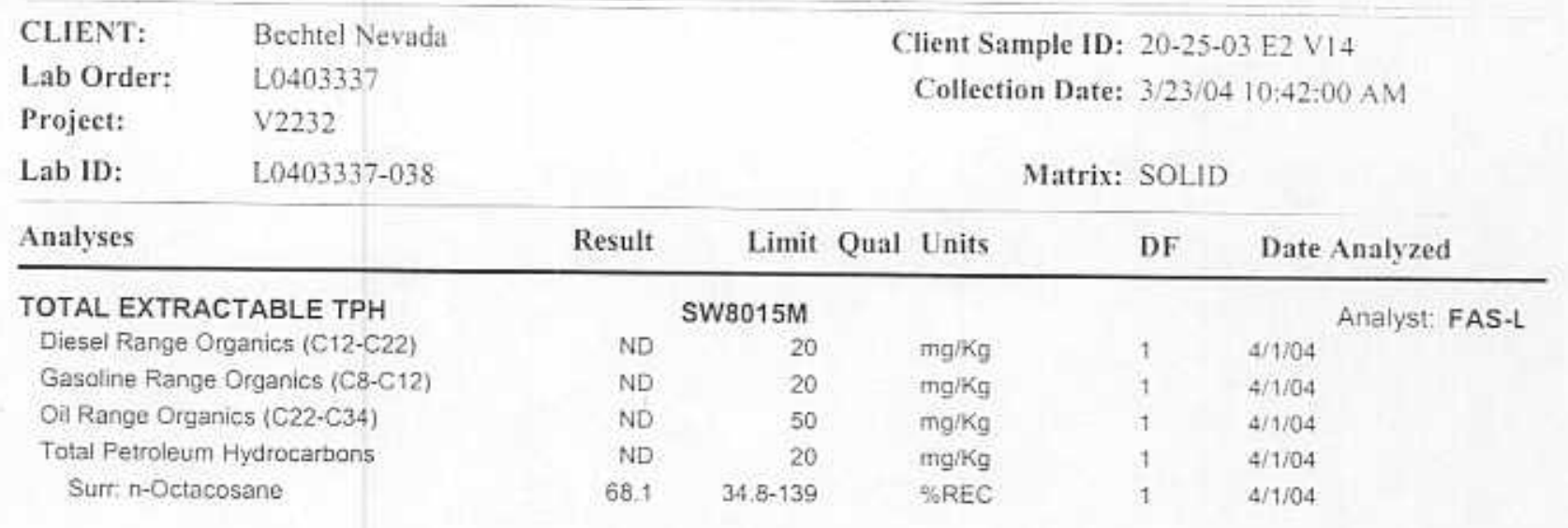

Qualifiers: $\quad$ ND - Not Detected at the Reporting Limia

1. Analyte defected below quanititation limits

B. Aralyte detected in the associated Method Blank

*. Value exceeds Maximum Contaminant Level
S-Spike Recovery oatside aecepted recovery limits

R - RPD outside accepted recovery limits

E- Value above quantitation range

Page 38 of 40 
NEL Laboratories, Las Vegas

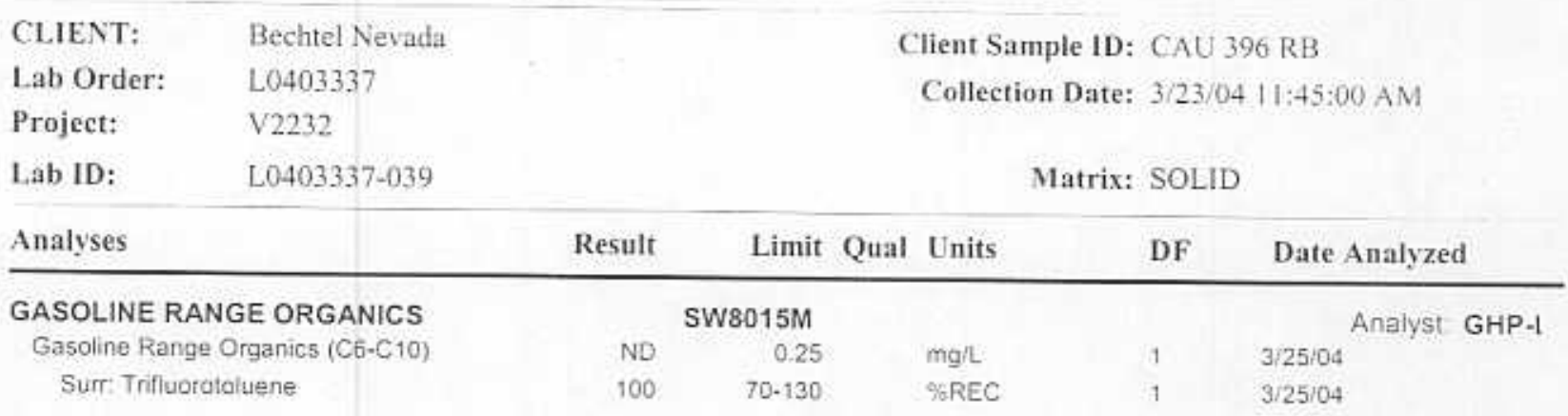

Date: $\left.02-d p r^{2}+1\right)+$ 
NEL Laboratories, Las Vegas

\begin{tabular}{ll} 
CLIENT: & Bechtel Nevada \\
Lab Order: & L0403337 \\
Project: & V2232 \\
Lab ID: & L0403337-040 \\
Analyses & \\
\hline TOTAL EXTRACTABLE TPH \\
Diesel Range Organics (C12-C22) \\
Gasoline Range Organics (C8-C12) \\
Oil Range Organics (C22-C34) \\
Total Petroleum Hydrocarbons \\
Surr: n-Octacosane
\end{tabular}

Date: $02-4 p r-10 \rightarrow$

Client Sample ID: CAU 396 RB

Collection Date: 3/23/04 11:45:00 AM

Matrix: AQUEOUS

\begin{tabular}{rrrll} 
Result & Limit Qual Units & DF & Date Analyzed \\
ND & SW8015M & & & \multicolumn{2}{c}{ Analyst: FAS-L } \\
ND & 0.50 & $\mathrm{mg} / \mathrm{L}$ & 1 & $3 / 29 / 04$ \\
ND & 0.50 & $\mathrm{mg} / \mathrm{L}$ & 1 & $3 / 29 / 04$ \\
ND & 0.50 & $\mathrm{mg} / \mathrm{L}$ & 1 & $3 / 29 / 04$ \\
85.0 & 0.50 & $\mathrm{mg} / \mathrm{L}$ & 1 & $3 / 29 / 04$ \\
& $56.6-139$ & \%REC & 1 & $3 / 29 / 04$
\end{tabular}

Qualifiers: ND-Not Detected at the Reporting Limit

1.-Analyte detected below quanititation limits

B - Amalyte detected in the associatud Methed Blank

- Valuc exceeds Maximum Contaminant Level
S. Spike Recovery outside aceepted recovery limits

R - RPD outside ascepted recovety limits:

E - Value above quantitation range

Page 40 of 40 
$v_{1}$

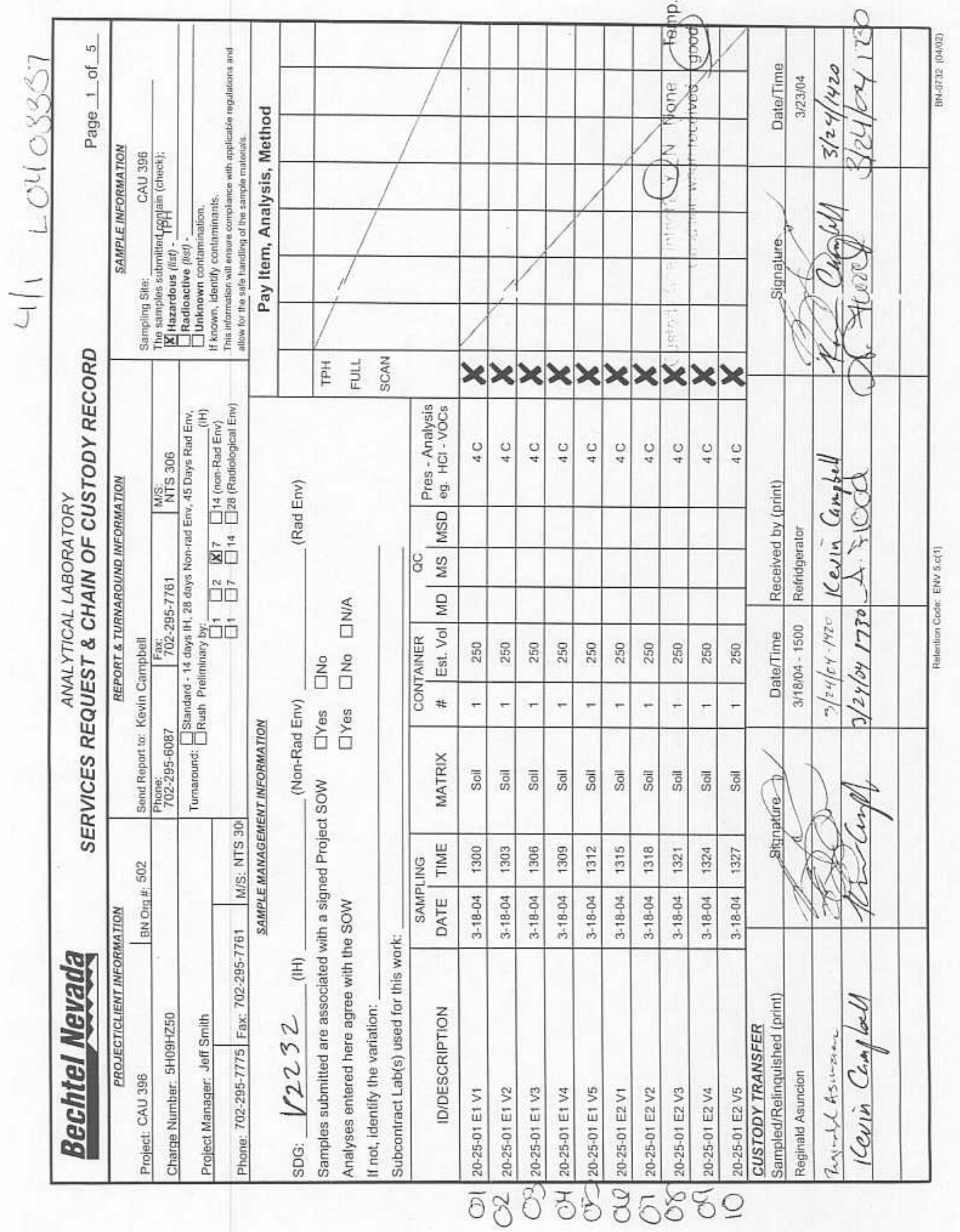




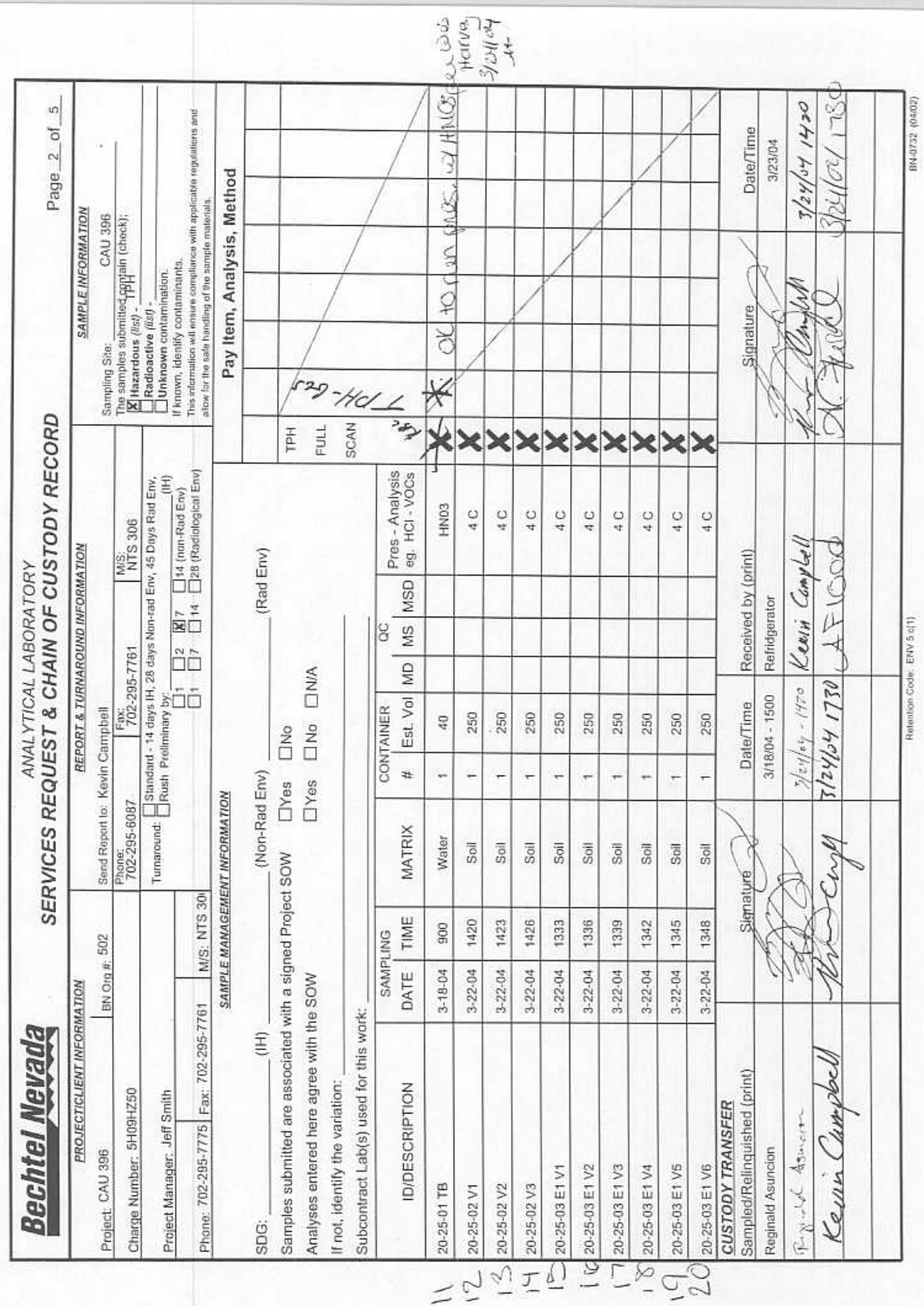




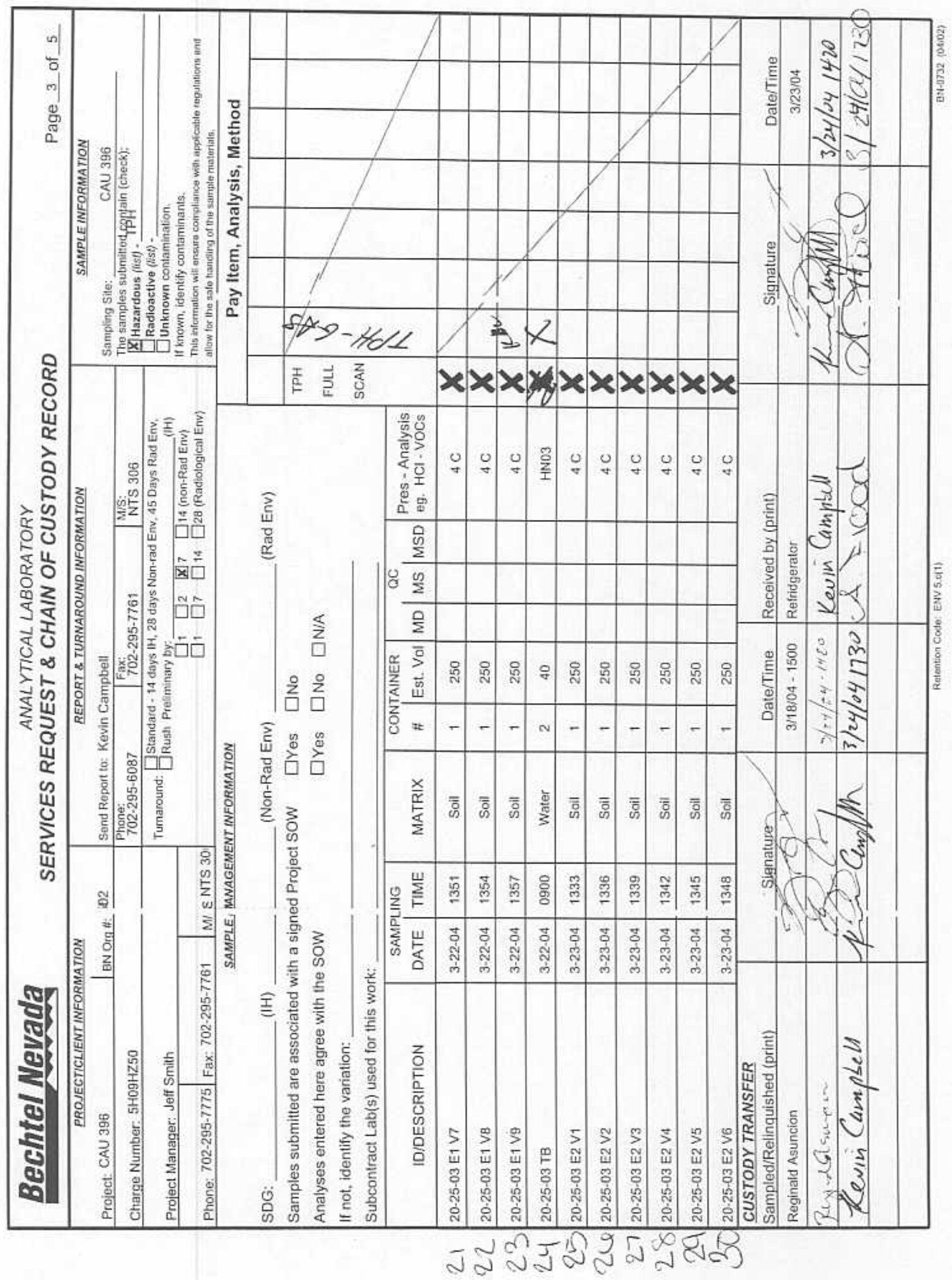




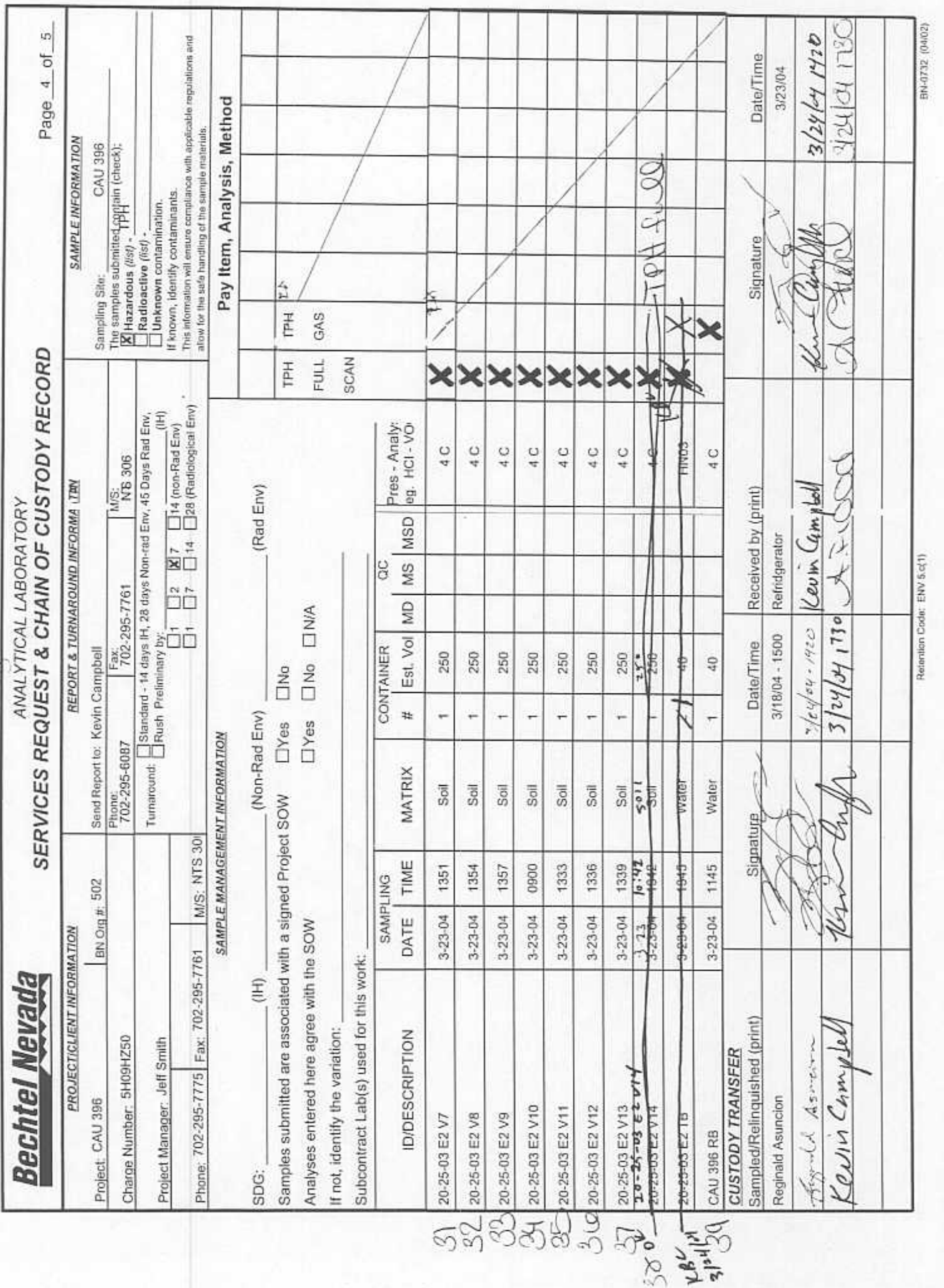




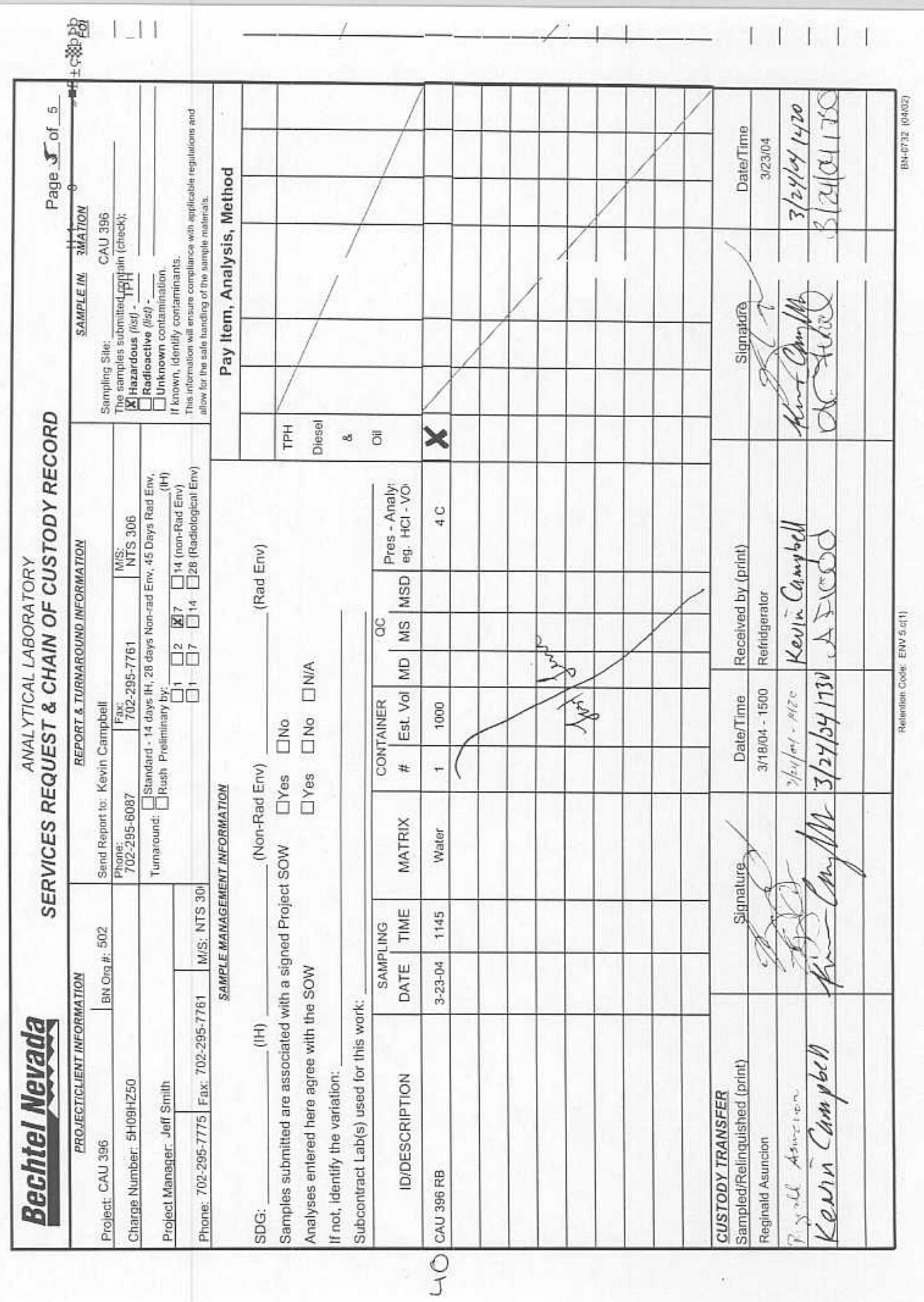




\section{NEL Laboratories, Las Vegas}

\section{Sample Receipt Checklist}

Client Name BECNEV

Work Order Numbe L L 0403337

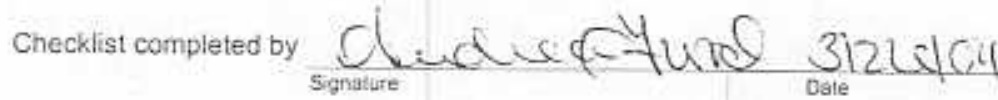

Matrix

Shipping container/cooler in good condition?

Custody seals intact on shippping container/cooler?

Custody seals intact on sample botties?

Chain of custody present?

Chain of custody signed when relinquished and received?

Chain of custody agrees with sample labels?

Samples in proper containerfoottle?

Sample containers intact?

Sufficient sample volume for indicated test?

All samples received within holding time?

Container/Temp Blank temperature in compliance?

Water - VOA vials have zero headspace?

Water - pH acceptable upon receipt?

No VOA vials submitted

Yes $\underline{v}$

Adjusted? NO

\section{Carrier name Kevin Campbell}

Dale and Time Receive

$3 / 24 / 045: 30: 00 \mathrm{PM}$

Reviewed by

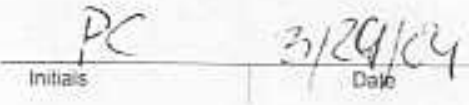


Friday, April 09, 2004

Ted Redding

Bechtel Nevada

P.O. Box 98521 , M/S NTS273

Las Vegas, NV 89193-8521

TEL: 702-295-7220

FAX: (702) 295-3069

RE Project: V2243

Order No.: L0404096

Dear Ted Redding:

NEL Laboratories, Las Vegas received 4 samples on 4/8/04 9:30:00 AM for the analyses presented in the following report.

The case narrative for the project listed above specifies all quality assurance deficiencies associated with the data. Data that is not qualified in the case narrative has met or exceeded the US-EPA or laboratory specifications for the analytical method.

If you have any questions regarding these tests results, please feel free to call.

\begin{tabular}{ll} 
John h/Wherspon \\
\hline Whn Witherspoon \\
Organic Supervisor \\
\\
Certifications: \\
\\
Washington & C325 \\
Idaho & NV052 \\
Nevada & NV052 \\
California & 2002
\end{tabular}

$\frac{y-9-0 y}{\text { Date }}$




\section{CLIENT: Bechtel Nevada}

Project: V2243

Lab Order: $\quad$ L0404096

\section{CASE NARRATIVE}

Date: 09-Apr-04

Attached are the analytical results for samples in support of the above referenced project.

The samples submitted for this project were not sampled by NEL. Should you have any questions or comments, please feel free to contact our Client Services Department.

Analytical Comments: None. 


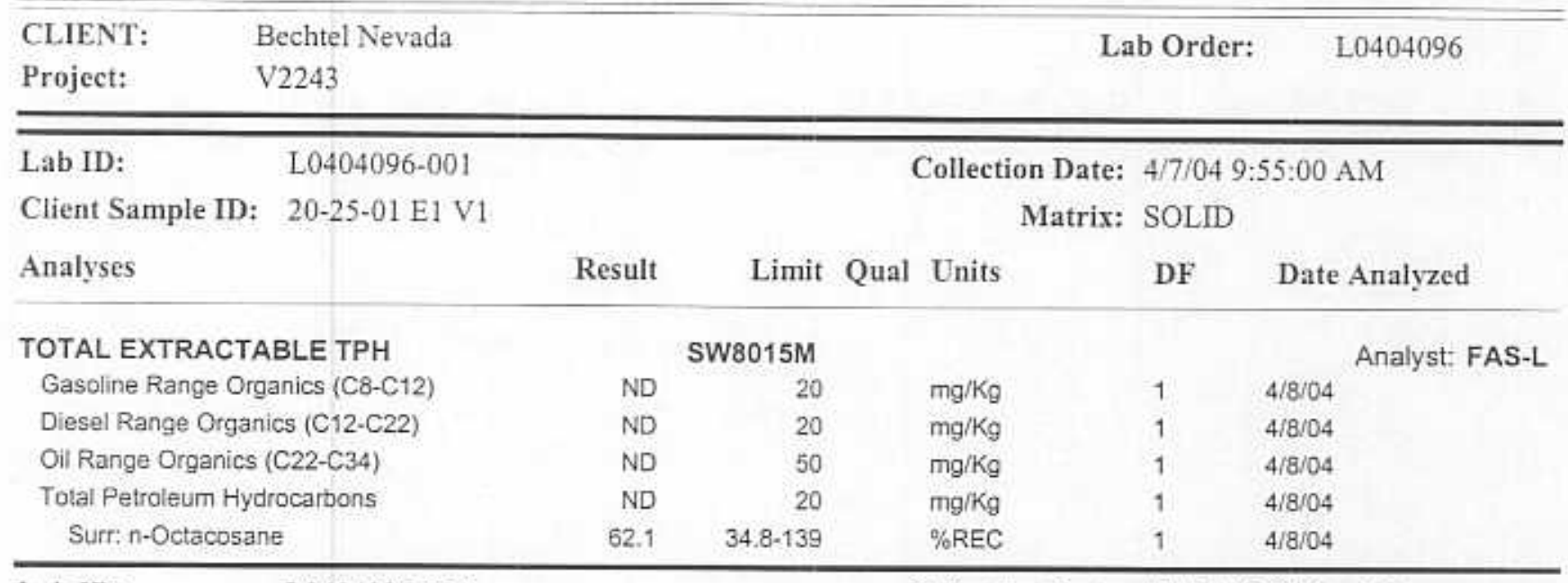

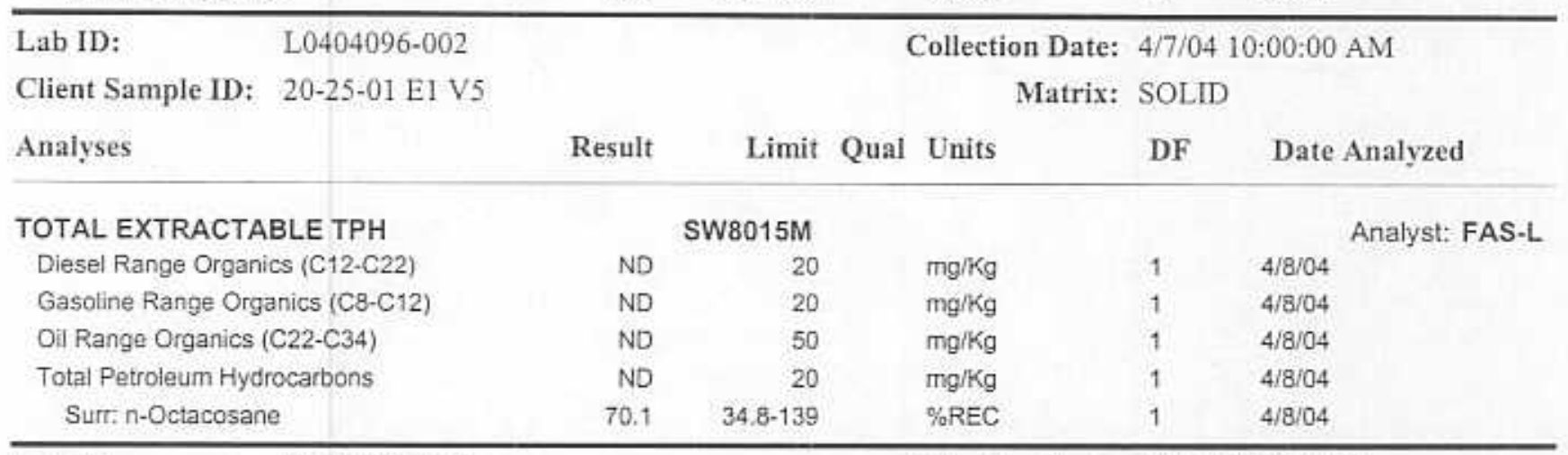

Lab ID: L0404096-003

Client Sample ID: $\quad$ 20-25-03 E1 V9

Analyses
TOTAL EXTRACTABLE TPH
Diesel Range Organics (C12-C22)
Gasoline Range Organics (C8-C12)
Oil Range Organics (C22-C34)
Total Petroleum Hydrocarbons
Surr: n-Octacosane

Lab ID: $\quad$ L0404096-004

Client Sample ID: $\quad$ 20-25-03 E2 V5
Result

Limit Qual Units

Collection Date: 4/7/04 1:00:00 PM

Matrix: SOLID 


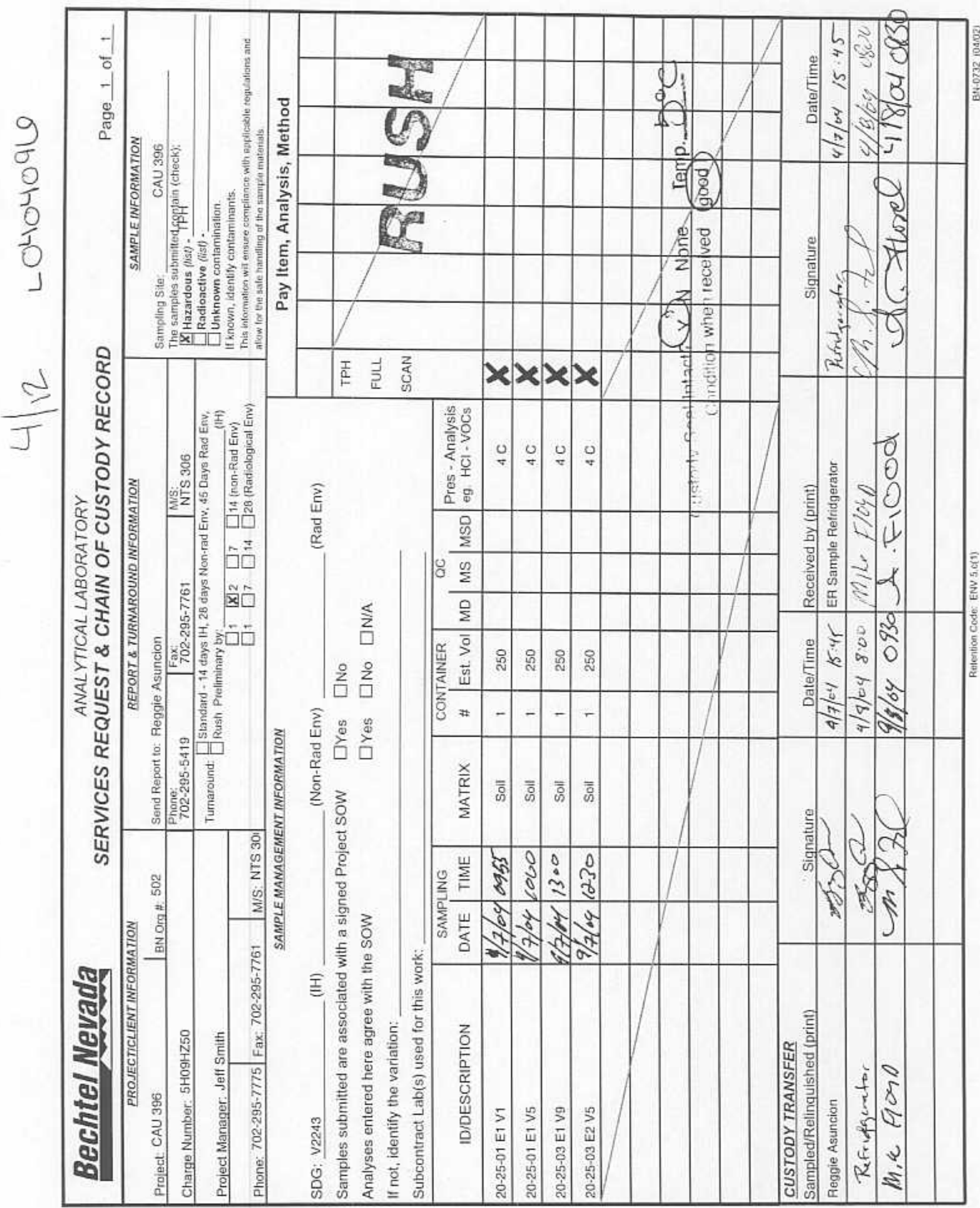




\section{NEL Laboratories, Las Vegas}

\section{Sample Receipt Checklist}

\section{Client Name BECNEV}

Work Order Numbe L0404096

Checklist completed by

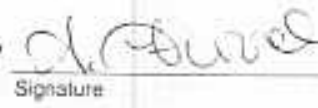

Matrix

Shipping container/cooler in good condition?

Custody seals intact on shippping container/cooler?

Custody seals intact on sample bottles?

Chain of custody present?

Chain of custody signed when relinquished and received?

Chain of custody agrees with sample labels?

Samples in proper containerbottle?

Sample containers intact?

Sufficient sample volume for indicated test?

All samples received within holding time?

Container/Temp Blank temperature in compliance?

Water - VOA vials have zero headspace?

Water - pH acceptable upon receipt?
Date and Time Receive

4/8/04 9:30:00 AM

Received by ARF-LV

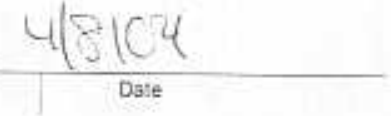

Carrier name Mike Floyd

Reviewed by

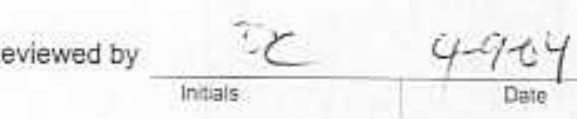

Adjusted?

Any No and/or NA (not applicable) response must be detailed in the comments section be

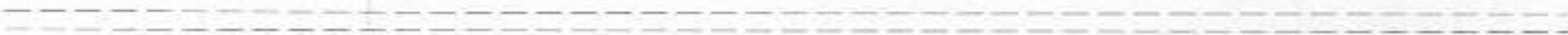

Client contacted

Date contacted:

Person contacted

Contacted by:

Regarding

Comments:

Corrective Action 
CLOSURE REPORT - CAU 396

Section: Appendix D

Revision: 0

Date: June 2004

CAS 20-99-08, SPILL

\section{WASTE CHARACTERIZATION RESULTS}


CLOSURE REPORT - CAU 396

Section: Appendix D

Revision: 0

Date: June 2004

THIS PAGE INTENTIONALLY LEFT BLANK 
To: Ronald Jackson

cc: Robert Bull

FFACO File

From: Frank M. Forsgren fing

Subject: CAU 396, CAS 20-99-08 Sampling Report

Date: March 20, 1998

Corrective Action Unit (CAU) 396, Corrective Action Site (CAS) 20-99-08, Spill, is located on the northeast edge of $U-20 b c$ in Area 20 of the Nevada Test Site (NTS). Sample team visits suggest the site consists of a bermed wash down area near the crater. An area estimated to be 200 feet squared is covered with a hard, brittle, gray material which the team suggested was a cement-based hardener or expoxy.

Sample ERSO0178 was collected on August 28, 1997. The sample consisted of soil and chips of the unidentified gray material. The intent of the sampling was to collect soil considered most likely to be contaminated to determine the identity of potential contaminants of concern (PCOCs). The soil samples were analyzed as total concentrations by Quanterra Environmental Services.

Review of the analytical results indicate some analyses are present at concentrations above detection limits, including:

- total Semivolatile Organic Compounds (SVOCs)

- total Polychlorinated Biphenyls (PCBs)

- total Resource Conservation and Recovery Act(RCRA)-8 Metals

- Radionuclides

Two PCOCs have been identified based on the comparison of the analytical results with the various regulatory guidelines, including both screening levels and action levels, as shown on Table F-I. Only those analytes which exceeded detection limits were compared to the regulatory guidelines.

Aroclor- 1248 and Arsenic have been identified as PCOCs. Aroclor-1248 exceeds the U.S. (EPA) Preliminary Remediation Goal (PRG) for residential soils. Arsenic exceeds the U.S. EPA. Generic Soil Screening Level (SSL) for ingestion.

IT digital photograph 209908pl was taken of the site on September 16, 1997.

Attachments: Attachment A-Sample Collection Log

Attachment B - Field Activities Daily Log

Attachment C - Analytical Results

Attachment D - IT Tier I and Tier II Data Verification Results

Attachment E - Radiological Data Review Results

Attachment F - Potential Contaminants of Concern and Criteria Table 


\section{CAU 396, CAS 20-99-08 Total Polychlorinated Biphenyl Analysis (by EPA Method 8015)}

03.Apr-98

\begin{tabular}{|c|c|c|c|c|c|c|c|}
\hline SAMPLE NUMBER & SAMPLE DATE & PARAMETER & RESULT & UNITS & DETECTION LIMIT & LAB QUALIFIER & IT QUALIFIEF \\
\hline ERS00178 & $8 / 28 / 97$ & Aroclor-1016 & 33 & UG/KG & 33 & U & \\
\hline ERS00178 & $8 / 28 / 97$ & Aroclor-1221 & 33 & UG/KG & 33 & U & \\
\hline ERS00178 & $8 / 28 / 97$ & Aroclor-1232 & 33 & UG/KG & 33 & $U$ & \\
\hline ERS00178 & $8 / 28 / 97$ & Aroclor-1242 & 33 & UG/KG & 33 & $U$ & \\
\hline ERS00178 & $8 / 28 / 97$ & Aroclor- 1248 & 99 & UG/KG & 33 & & \\
\hline ERS00178 & $8 / 28 / 97$ & Arocior-1254 & 33 & UG/KG & 33 & $\mathrm{U}$ & \\
\hline ERS00178 & $8 / 28 / 97$ & Arocior -1260 & 33 & UG/KG & 33 & $\mathrm{U}$ & \\
\hline
\end{tabular}




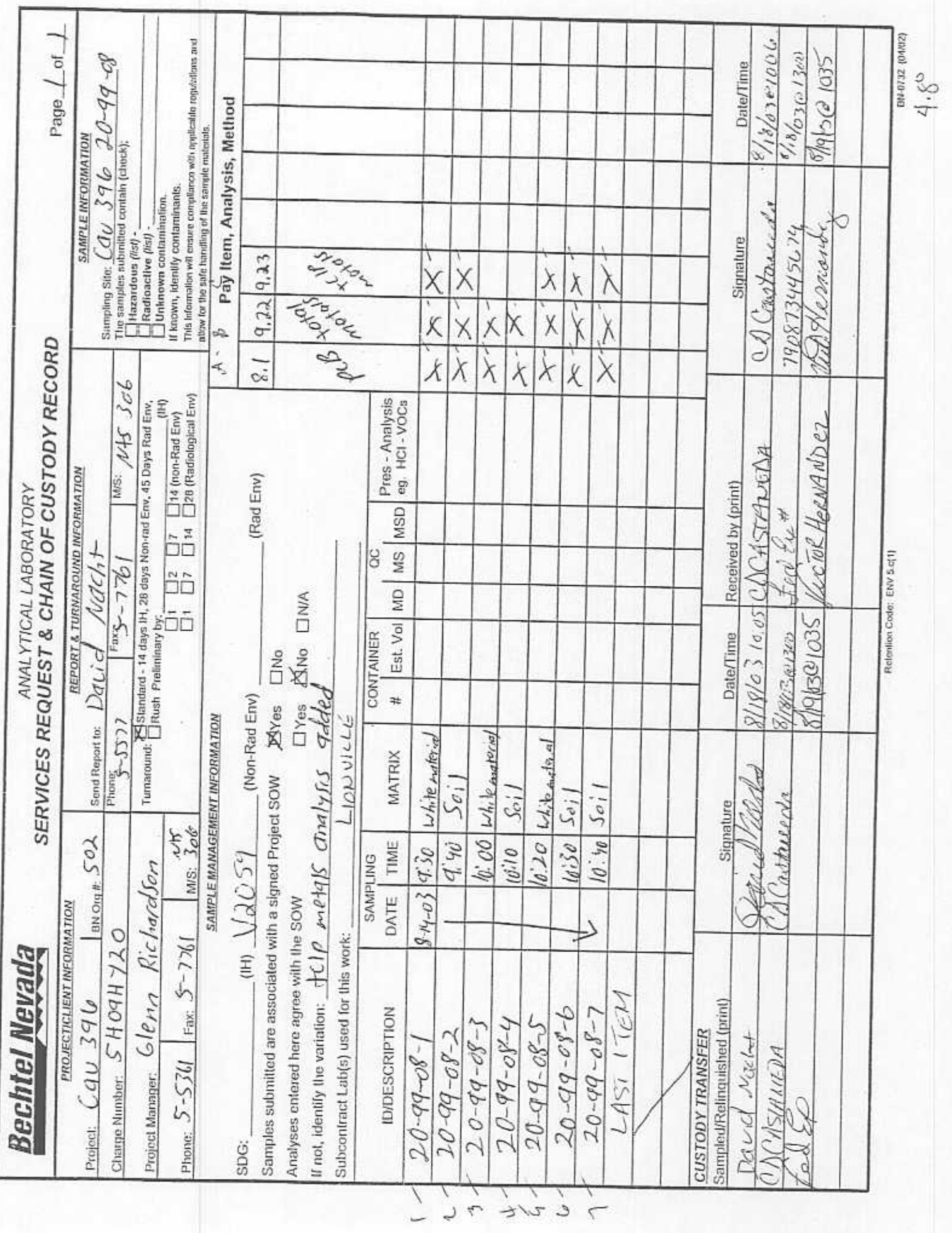




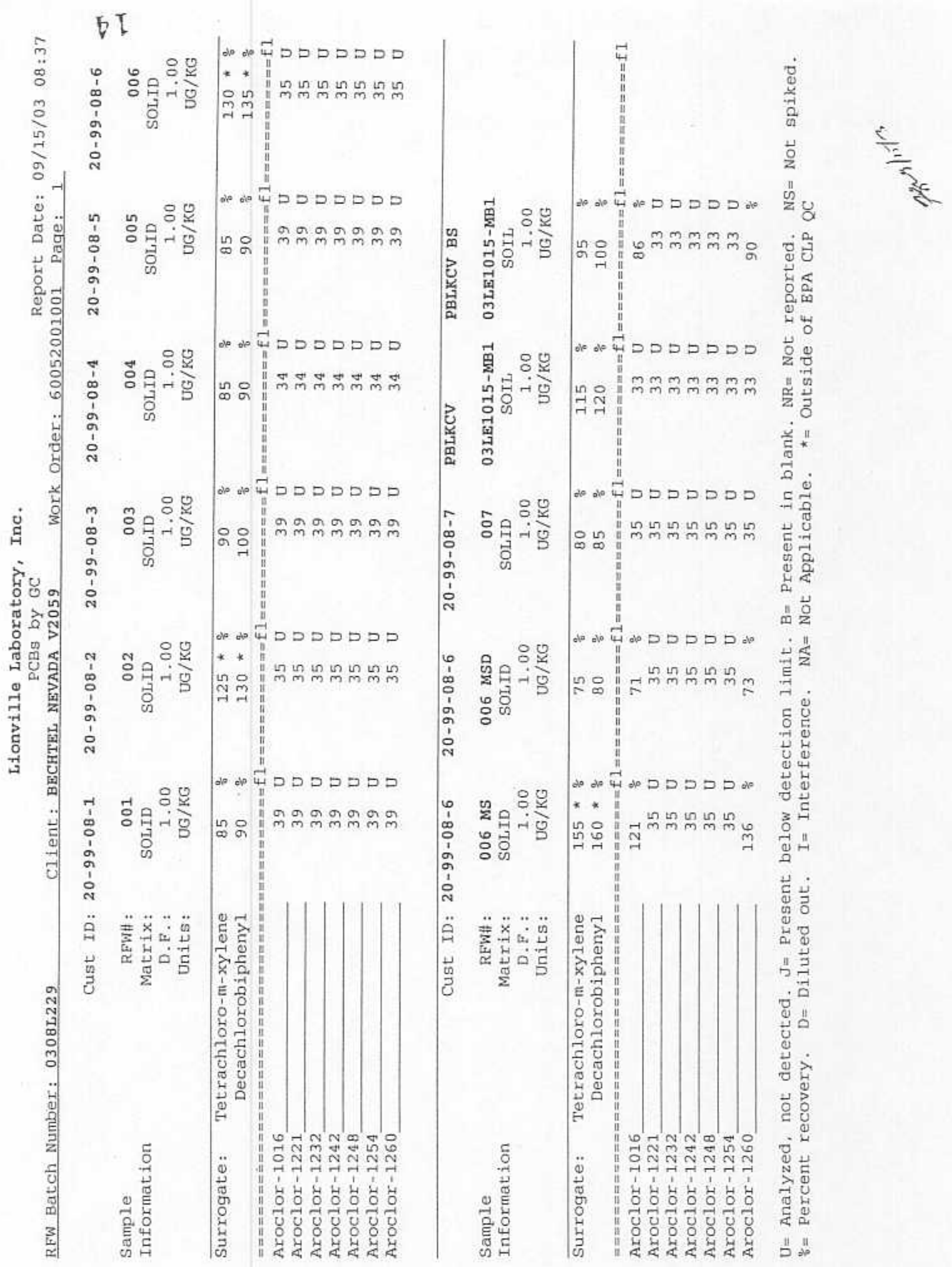


CLOSURE REPORT - CAU 396

Section: Appendix E

Revision: 0

Date: June 2004

\section{APPENDIX E}

\section{WASTE DISPOSITION DOCUMENTATION}


CLOSURE REPORT - CAU 396

Section: Appendix E

Revision: 0

Date: June 2004

THIS PAGE INTENTIONALLY LEFT BLANK 


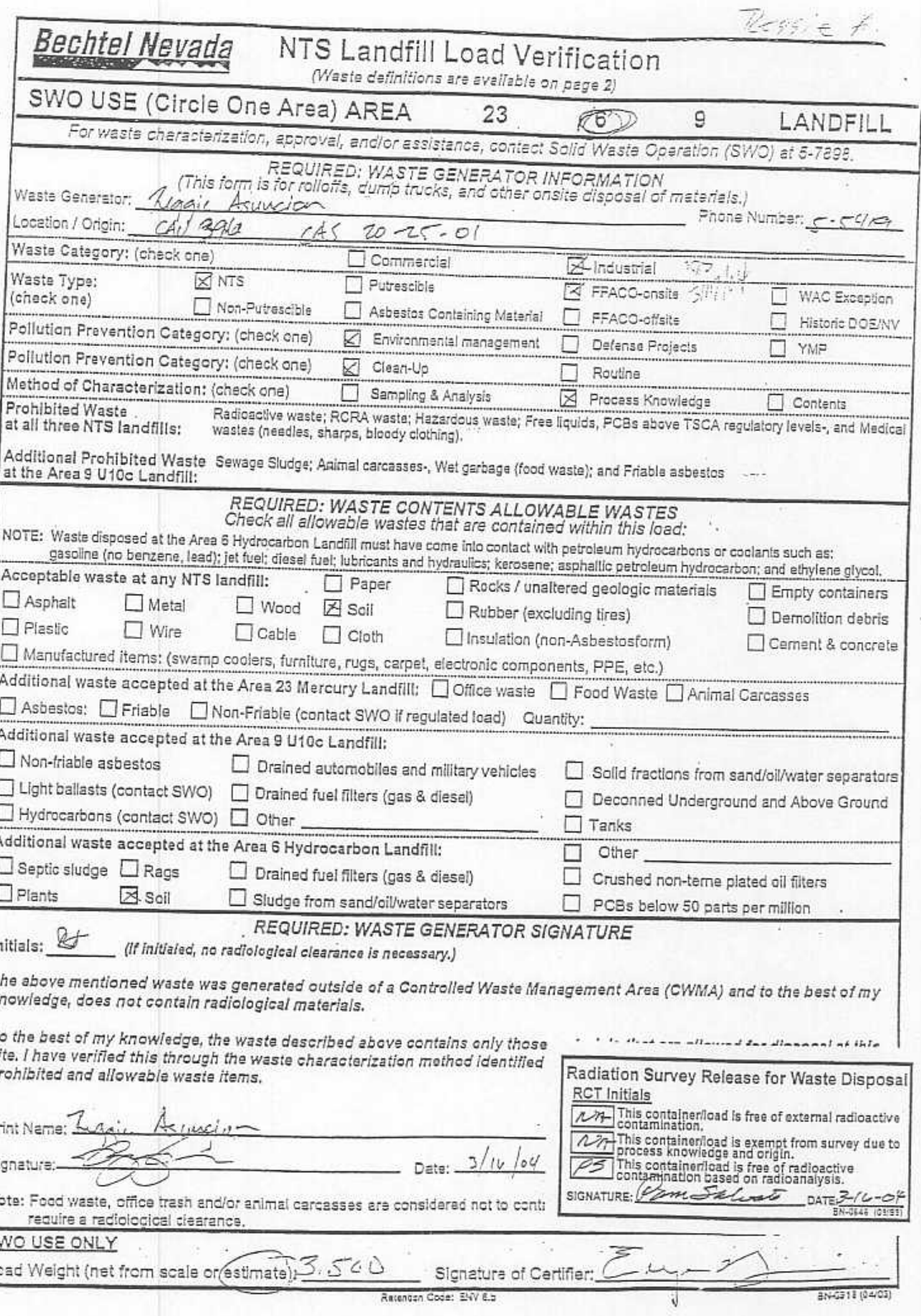




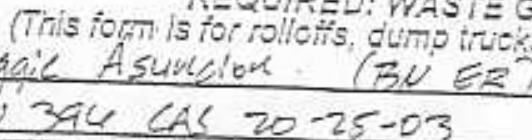

Location / Origin: $\frac{\mathrm{CAU} 3}{30}$

Waste Type:

(check one)

\section{$\triangle N T S$}

ZNon-Futrascibla

Pollution Prevention Category: (check one)

Poliution Pravention Category: (chack ons)

Method of Characterization: (check one)

Prohibited Waste

at all three NTS landfills:

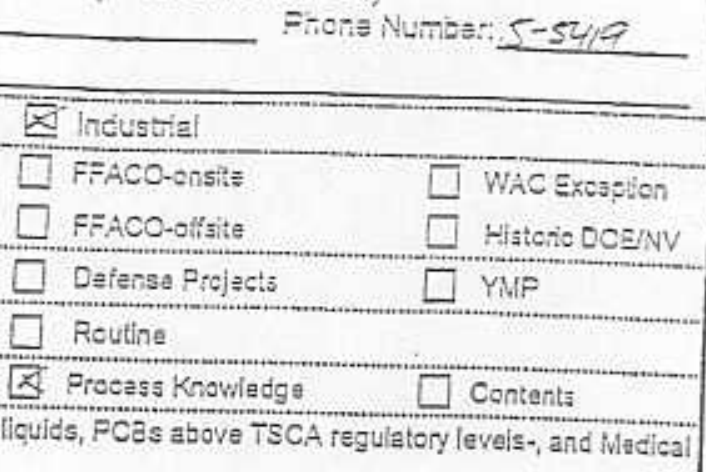
Erials. Thone Numban: 5-s4/9

Radjoactive waste; RCRA waste; Hazardo
wastes (needlas, sharps, blocdy clothing).

at the Area 9 U 100 Landfill:

Q Commarcial
$\square$ Putrescibia
$\square$ Asbesios Containing Material
区 Environmental managemant
Q Clean-Up
$\square$ Sampling 3 Analysis

\section{REQUIRED: WASTE CONTENTS ALLOWABLE WASTES}

Check all allowable wastes that are contained within this load: gasoline (no benzene Aread). Hydrocarbon Landfill must hava come into contact with petroleum hydrocarbons or coolants such as:

Acceptable waste at any NTS landfill:
$\square$ Asphalt
$\square$ Metal
Plastic
$\square$ Wood
$\square$ Paper
$\square$ Rocks / unaltered geologic materials
$\square$ Empty containers
$\square$ Rubber (excluding tires)
$\square$ Demolition debris
Cement \& concrete

Plastic $\square$ Wire $\square$ Cable $\square$ cloth $\square$ Insulation (non-Asbestosform)
Manuiactured items: (swamp coolers, furniture, rugs, carpet, electronic components, PPE, etc.)

$\square$ Wire $\square$ Cable $\square$ Cloth $\square$ Insulation (non-Asbestosform)
Manufactured items: (swamp coolers, furniture, rugs, carpet, electronic components, PPE, atc.)

Additional waste accepted at the Area 23 Mercury Landfill: $\square$ Office waste $\square$ Food Waste $\square$ Animal Carcasses

$\square$ Asbestos: $\square$ Friable $\square$ Non-Friable (contact SWO If regulated load) Quanilty:

Additional waste accopted at the Area 9 U10 Landfill:
Non-friable asbestos
Light ballasts (contact SWO)
Hydrocarbons (contact SWO)
Drained automobiles and military vehicles
Drained fuel filters (gas \& diesel)
Other

Additional waste accepted at the Area 6 Hydrocarbon Landfill:

$\square$ septic sludge $\square$ Rags

Dplants

D. Soil

$\square$ Drained fuel filters (gas \& diesel)

$\square$ Sludge from sand/oillwater separators

Initials: Re REQUIRED: WASTE GENERATOR SIGNATURE

Solid fractions from sand/oil/water separators

Deconned Underground and Above Ground Tanks The above mentioned waste was generated outslde of a Controlled Waste Management Aras (CWMA) and to the best of my
knowiedge, does not contain radiolog/cal materials.

To the best of my knowiedge, the waste described above centains only those $m$ site. I have veriffed this through the waste characterization methedidentified at prohibited and allowable waste items.

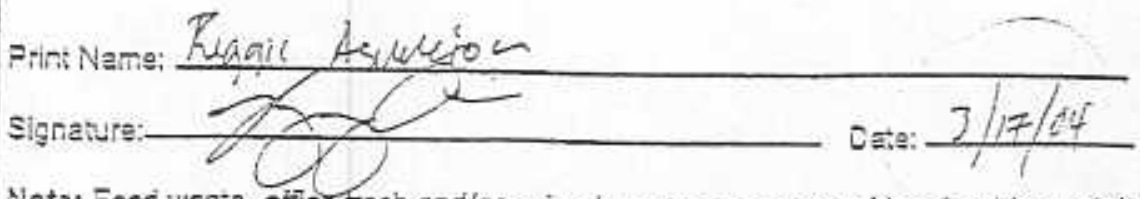

Note: Focd waste, orilce trash and/or enimal carcasses are esnsidered not to contel

Radiation Survey Release for Waste Disposal RCT Initials

NA This containeriload is free of external radioactive N/4 This containeriload is exempt from survey due to process knowledge and otigin.

This containeriload is free of radipactlve contamination based on radoanalysis.

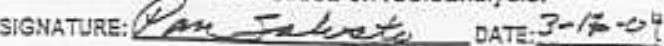
recuire a radiological claarance. SWO USE ONLY 
rlasta defintions ara avallable on page 2)

\section{SWO USE (Circle One Area) AREA}

for waste characterizetion, approval, andor assiatance, contact Solid Waste operation (SWO) at E.7jge.

REQUIRED: WASTE GENERATOR INFORMATION

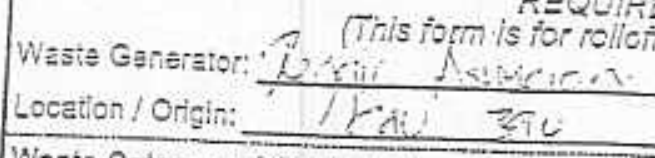

Waste Category: (chieck one)

Waste Type:
(check one)

$\square$ Nen-Fuiteseible

Pollution Preyention Category: (check one)

Pollution Frovention Category; (check ons)

Method of Characterization: (check one)

Prohibited Waste.

at all three NTS landfills:

$\angle A B+7,35-21$

$\square$ Commercial

— Asbesios Containing Material

[C] Environmentai managerment

[x Clean-Up

$\square$ Sampling 3 Analysis

Racioaclive waste; RCRA waste; Hazardous waste;

Industrial
$\square$ FFACO-onsita

$\square$ FACO-Offits atistals.! Phonenumber: $5-54$ in

at the Area 9 U10c Landfill:

\section{REQUIRED: WASTE CONTENTS ALLOWABLE WASTES}

NOTE: Waste disposed at the Area 6 Hych all allowable wastes that are contained within this load. gasoline (no benzene, lead): jet fuel, diesel fuel lubricants ave come inlo contact with petroleum hydrocarbons or coolanis such as:
Acceptable waste at any NTS landiill:
$\square$ Asphalt $\triangle$ Metal
В Plastic
$\square$ Wira
$\square$ Wood
$\square$ Paper
[C] Soll
$\square$ Cable $\square$ Cloth
$\square$ Rocks / unaltered geologic materials
$\square$ Rubber (exciuding tires)

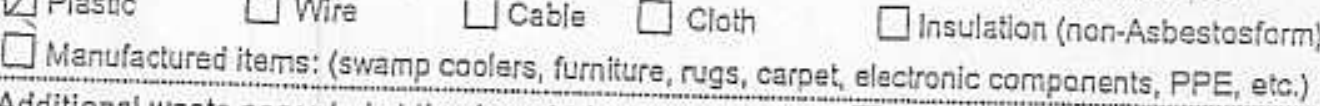

Additional Waste accepted at the Area 23 Mercury Landfill: $\square$ Office waste $\square$ Food Waste $\square$ Animal Carcasses

$\square$ Asbestos: $\square$ Friable $\square$ Non.Friable (contact SWO if regulated load) Quantity:

Additional waste accepted at the Area 9 U10 Landfill:
$\square$ Non-friable asbestos
Light ballasts (contact SWO)
Hydrocarbons (contact SWO)
Drained automobiles and military vehicles
Drained fuel filters (gas \& diesel)
Other

Additional waste accepted at the Area 6 Hydrocarbon Landfill:

$\square$ Septic sludge $\square$ Rags $\square$ Drained fuel fiters (gas \& diesel)

$\frac{\square \text { Soil } \$ \text { Sludge from sand/oil/water separators }}{\text { REQUIRED: WASTE GENERATOR }}$

Initials: \& A (If initaled, no radiological clearance is necessary.)

$\square$ PCBs below 50 parts per million

Solid fractions from sand/oil/water separators

Deconned Underground and Above Ground Tanks

[1 Other

Crushed non-teme plated oil filters The above mentioned waste was generated outside of a Controlled Waste Management Area (CWMA) and to the best of my
knowledge, does not contain radiological materials.

To the best of my knowiedge, the waste deseribed above contains only those mat site. I have verified this through the waste characterization method identifled abol prohibited and allowable waste liems.

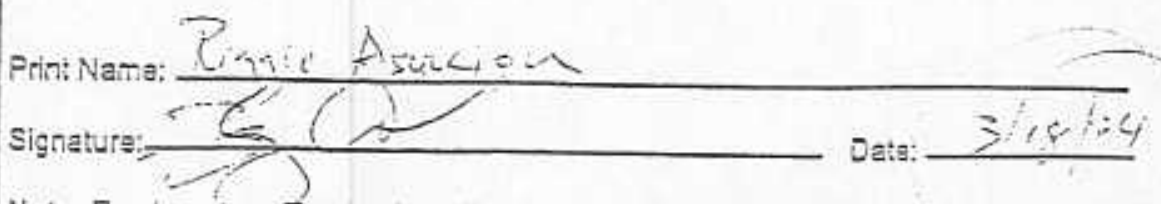

Radiation Survey Release for Waste Disposal RCT Initials

This containeriload is free of external radloactive contamination.

This containeriload is exemot from sirvgy due to

This containeritoad is exempt fi
process knowiedge and origin.

This containeriload is froe of radioactive contaminationojased on gadioagalysis.

SIGNATURE:

\%

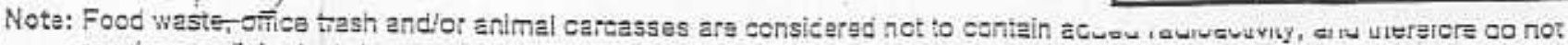
recuire a ractological clearancs.

\section{SWO USE ONLY}

Load Weight (net from scale gipestmate) $<4 / 32$

Signature of Certitiar 


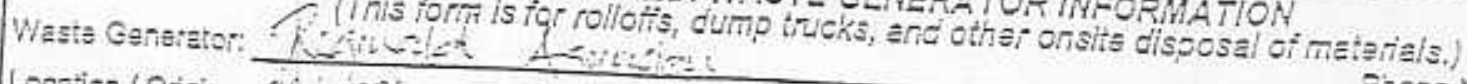

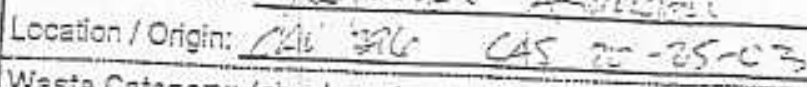
Phone Number: $5-54$ Waste Category: (chock one)

Waste Type:

(check one)

IITS

$\square$ Non-Puitescibla

\section{$\square$ Commercial \\ प Putreseible}

Pollution Prevention Catagory: (check one)

Pollution Prevention Category: (check ons)

Method of Characterization: (check one)

$\square$ Asbestos Containing Matarial

$\triangle$ Environmental management

[x Clean:Up

Prohibited Waste

$\square$ Sampling \& Aralysis

Radioaclive waste; RCRA waste; Hazardous......... Procass Knowledge

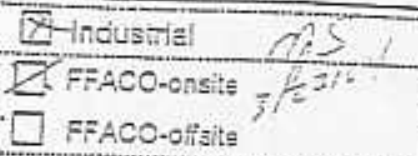

WAC Exsoption

$\square$ Defense Frojects

Histeric DOEINV

at all three NTS landfills;

wastes (needles, sharps, bloody clothing).

Additional Prohibited Wast

at the Area 9 U $10 \mathrm{c}$ Landfill:

\section{Sewage Sludge; Animal carcasses-, Wet garbage (food waste); and Friable asbestes}

\section{REQUIRED: WASTE CONTENTS ALLOWABLE WASTES}

NOTE: Waste disposed at the Area 6 Hydrocall allowable wastes that are contained within this load gascline (no benzere, lead); jet fuel; diesel fuel; lubricants ane come into contact with petroleum hydrocarbons or coolants such as:

Acceptable waste at any NTS landfill:
$\square$ Asphatt
$\square$ Metal
$\square$ Wood $\mathrm{X}$ Soil
$\square$ Plastic
$\square$ Wire
$\square$ Cable
$\square$ Cloth
$\square$ Rubber (exclucing tires)
$\square$ Insulation (non-Asbestasform)
Emply containers
Demolition debris

Manufactured items: (swamp coolers, furniture, rugs, carpet, electronic components, PPE, etc.)

Additional waste accepted at the Area 23 Mercury Landfill: $\square$ Office waste $\square$ Food Wasta $\square$ Animal Carcasses

$\square$ Asbestos: $\square$ Friable $\square$ Non-Friable (contact SWO if regulated load) Quantity:

Additional waste accepted at the Area $9410 \mathrm{c}$ Landfill:

$\square$ Non-filiable asbestos

$\square$ Light ballasts (contact SwO)

Hydrocarbons (contact SWO)

Drained automobiles and milltary vehicles

Orained fuel filters (gas \& diesel)

Other

Additional waste accepted at the Area 6 Hydrocarbon Landfill:

$\square$ Septic sludge $\square$ Rags

Drained fuel filters (gas \& diesel)

$\square$ sludge from sand/oillwater separators

REQUIRED: WASTE GENERATOR SIGNATURE

Initials: 21 . (If initialed, no raoiological clearance is neeessary.) The above mentioned waste was generated outside of a Controlled Waste Management Area (CWMA) and to the best of my
know/edge, does not contain radiological materials.

To the best of my knowiedge, the waste described above contalns only those site. I have verified this through the waste characterization method identified prohibited and sllowable waste items.

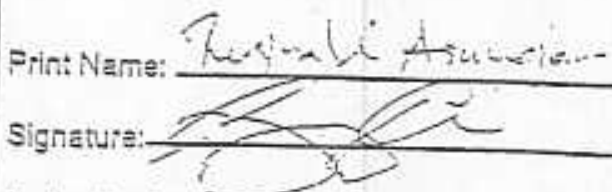

Radiation Survey Release for Waste Disposal RCT Initials This containeriload is free of external racioactive
contamination.

This containeriload is exempt from survay due to

Date: $3 /=2 / 5 y$

Note: Food wasta, office tresh andoi animal carcasses are considered not to conta recuire a radiological claarancs.

SWO USE ONLY

Load Weight (net from scale or estimate): $4 \leq 4 \leq 22$ Signature of Certifier: 


\section{Bechtel Heyada NTS Landfill Load Verification}

Praste doinititons are avallable on page 2)

SWO USE (Circle One Area) AREA

23

9

LANDFILL

For Waste characterization, aporoval, endlor assistance, contact Solld Waste Operation (SW/O) at 3-7asa.

REQUIRED: WASTE GEMERATOR INFORMATION

Waste Ganeizton: of, (This form is for ro

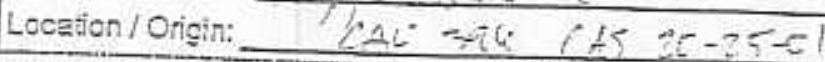

Waste Category: (check one)

Waste Typs:

ne)

(check one)

NIS

$\square$ Non-Futrescible

$\square$ Commercial
$\square$ Putescisle

Pollution Prevention Category: (check one)

Pollution Prevention Category: (check one)

Method of Characterization: (check one)

Prohibited Waste

$\square$ Asbustco Containing Material

34 Environmental manggement.

$\triangle$ Clean.Up

$\square$ Sampling \& Analysis

ther on

ite disposel of materials.) Fherie Number: r-guh

at all three NTS landills:

Racloaclive waste; RCRA waste; Hazardo
wastes (needles, sharps, bloody clothing).

Additional Prohibited Waste Sewage Sudgai A

at the Area $9 \cup 10 \mathrm{c}$ Landfill:

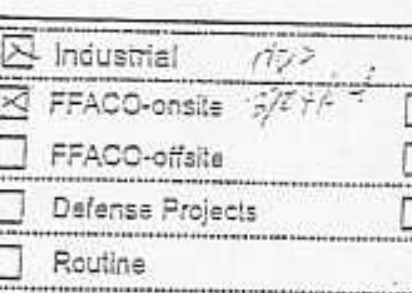

$\square$ WAC Exsoftion
$\square$ Fistcic DOETYV
$\square$ YMP
$\square$ Contents

区 Process Knowladge

Contents

\section{REQUIRED: WASTE CONTENTS ALLOWABLE WASTES}

Check all allowable wastes that are contained within this load:

NOTE: Waste disposed at the Area 6 Hydrocarbon Landfill must have come inlo contact with petroleum hydrocartons or coolants such as: gasoline (no benzene, lead); Je: fuel; diesel fuel; lubricants and hydraulles; kerosene; asphaltie petroleum hydrocarbon; and elthylene glyeol,

Acceptable waste at any NTS landfill: . $\square$ Paper $\quad$ Rocks / unaltered geologic materials $\square$ Empty containers
$\square$ Asphalt
$\square$ Metal
$\square$ Wood
Q
$\square$ Plastic
$\square$ Wire
$\square$ Cable
$\square$ Cloth
$\square$ Rubber (excluding tires)
$\square$ Insulation (non-Asbestosform)
Demolition debris

Cement \& concrete

$\square$ Manufactured items: (swamp coolers, furniture, rugs, carpet, electronic components, PPE, etc.)

Additional waste accepted at the Area 23 Mercury Landfill: $\square$ Office waste $\square$ Food Waste $\square$ Animal Carcasses

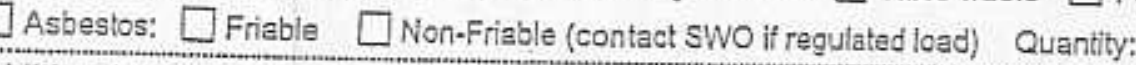

Additional waste accepted at the Area $9 \cup 10 \mathrm{c}$ Landifll:

$\square$ Non-friable asbestos $\quad \square$ Drained automobiles and military vehicles
$\square$ Light ballasts (contact SWO) $\square$ Drained fuel filters (gas \& dlesel)
$\square$ Hydrocarbons (contact SWO) $\square$ Other

Additional waste accepted at the Area 6 Hydrocarbon Landfill:

$\square$ septic sludge $\square$ Rags $\square$ Drained fuel filters (gas \& diesel)

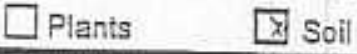

$\square$ Sludge from sand/oil/water separators

Solid fractions from sand/oil/water separators

$\square$ Deconned Underground and Above Ground Tanks

Initials: R.A (lf initialed, no radiological clearance is necessary.)

The above mentioned Waste was generated outside of a Controlled Waste Management. Area (CWMA) and to the best of my knowledge, does not contain radiological materials.

To the best of my knowledge, the waste described above contains only those materlals that are allowed for disposal at this site. I have verifiod thils through the waste characterization method identiffed abova and a ..............

prohiblted and allowable waste items.

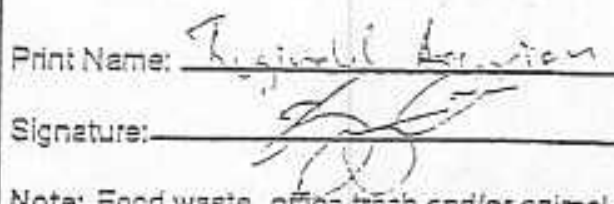

Radiation Survey Release for Waste Disposal RCT Initials

A This contalnerload is free of external radioactive A. contamination.

i/f This containerlioad is exompt ffom

75 This container/load is free of radioactive

15 This container bad is free of radolysis.

Note: Food waste, ofice thăsh andfor animal carcasses are considered not to contain reguire a radiological clearenes.

SWO USE ONLY

Load Weight (net from scale of estimats): 36970

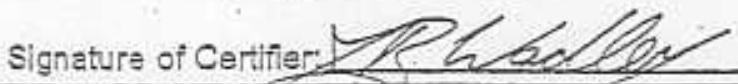


Wasta Generato: 1 i This form is for rolloüts, dump trucks, and other onsite diseosal of materials.

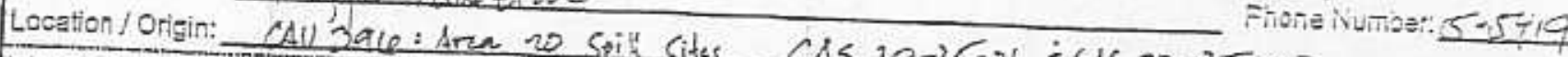

Waste Category: (check one) CAs $20-25-01 \div(A S 20-25-03$

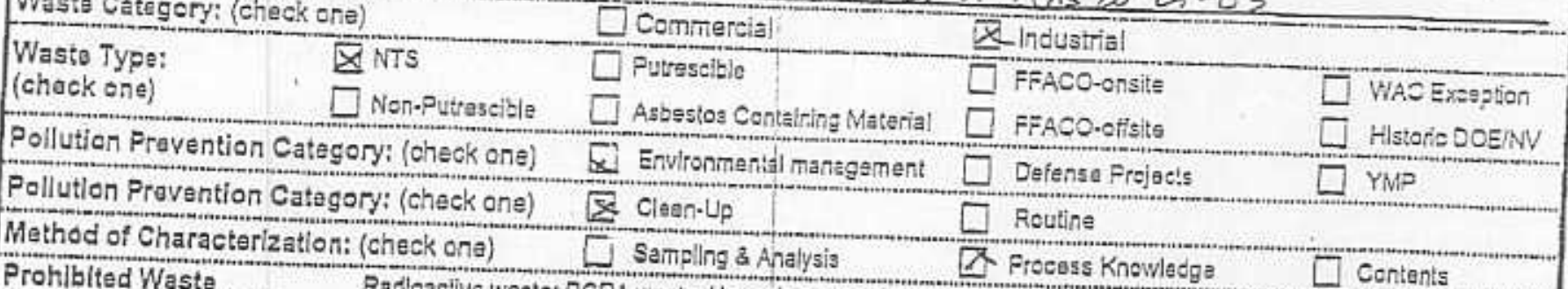

Sempllng a Analysis _......... Froesss Knowledge $\square$ Contents

at all throe NTS landfills; Wastas (neadles, gharps, bloody clothlng).

Additional Prohibited Waste Sawa Stodg firm

at the Area 9 U10e Landfill:

\section{REQUIRED: WASTE CONTENTS ALLOWABLEWASTES
Check all allowable wastes that are contained within this load}

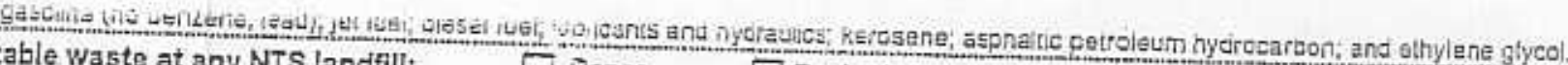

Acceptable waste at any NTS landfill: $\square$ Paper $\square$ Rocks / unaltered geologic materials $\square$ Empty cantainers
$\square$ Asphalt
$\square$ Metal
$\square$ Wood
¿ Soll
$\square$ Plastic
$\square$ Rubber (excluding tires)

$\square$ Wire

$\square$ Cable

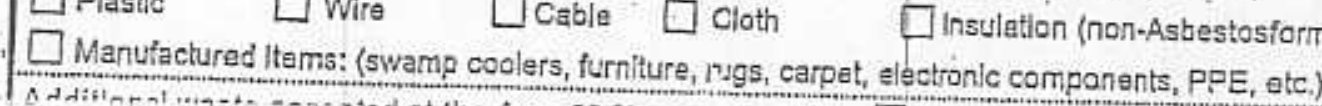

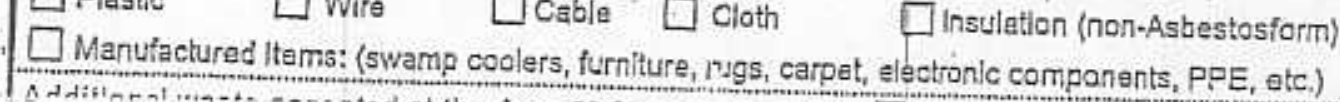

Demolition debris

$\square$ Asbestog:

Asbestos: $\square$ Frlable $\square$ Non-Friable (contact SWO if regulated load) Quantity:

Additional waste accepted at the Area 9 U10 Landflli:

$\square$ Non-friable asbestos

Light ballasts (contact SWO)

Hydrocarbons (contact SWO)

$\square$ Dralned automoblles and militery vehicles

Drainad fuel filtars (gas \& diesei)

Othar

Additional waste accopted at the Area 6 Hydrocarbon Landfill;

$\square$ septic sludge $\square$ Rags

$\square$ plants

x) Soll $\square$ Drained fuel fillers (gas \& diesel)

$\square$ sludge from sandlollwater soparators
Solld fractions from sand/oil/water separators

Deconned Underground and Above Ground Tanks

Other

Crushed non-terne plated oil rilters

FCBs below 50 parts per million

\section{Initlals: $2 \cdot 1$ (If inittaled, no radiological elearance is necessary.)}

\section{REQUIRED: WASTE GENERATOR SIGNATURE} The above mentioned waste was generated outslita of a Contro/led Waste Management Area (CWMA) and to the best of my
knowledge, does net contain radiological materia/s.

10 trie vest of my knowiegge, the waste descheet adove contarns only thosi site. I have veriflod thls through the waste characterization method identifiec prohibited and allowablo waste items.

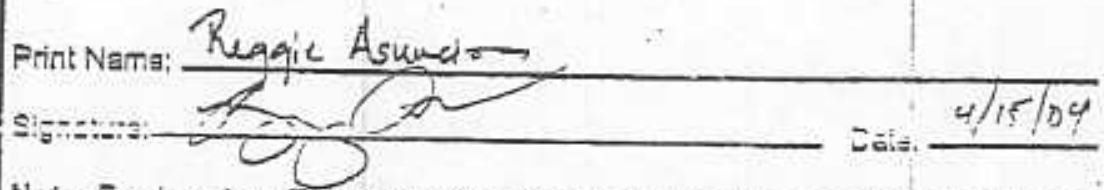

RCT Initials

This containorload is iree of external radioactivo contamination.

This containeriload is exempt from survery due to process knowlodge and origin.

This containeriload is free of radloactive contamination uased og radlganalysis.

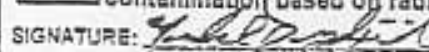
DATE $4 / 15 / 04$

Nota: Food waste, office trash andior animal carcase $;$; are considered not to contain added radioactivity, end therniore do not reculre a radiclogical clearance.

SWO USE ONLY

Load Weight (net from scale or estimate): Shor) Signature of Certifler: 
SWO USE (Circle One Area) AREA difitions ara avellatle on paga 2)
Area) AREA
23
(6)
9
LANDFILL
REQUIRED: WASTE GENERATOR INFORMATION

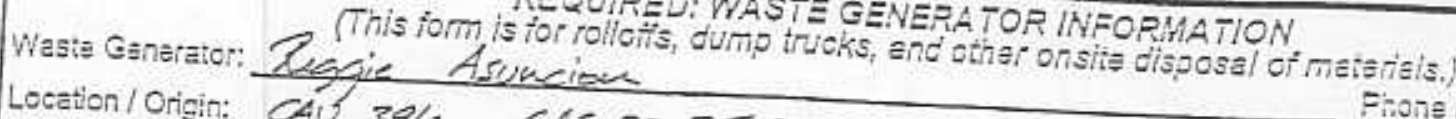

Wasta Category: (check 396 CA5 $20-25-03$

Waste Type: \NTS

(check one)

Pollution Prevention Category: (check one)

$\square$ Commercial

Pollution Frevention Category: (check one)

Method of Characterization: (check one)

Prohibited Waste

$\square$ Sampling \& Analysis

$\square$ Putressiole

$\square$ Asbestos Containing Material

¿ Environmental management

$凶$ Clean.Up

Finone Numibe: $5-54 / 0$

at all three NTS landfills:

wastes (needles, sharps, bloody elothing).

Additional Prohibited Waste
at the Area $9 \cup 10 \mathrm{c}$ Landfill:

\section{REQUIRED: WASTE CONTENTS ALLOWABLE WASTES}

NOTE: Waste disposed at the Area 6 Heck all allowable wastes that are contained within this load: gasoline (no benzene, lead); jet fuel; diesel fuelt fubricants and home into conlact with petroleum hydrocarbons or coclanls such as:

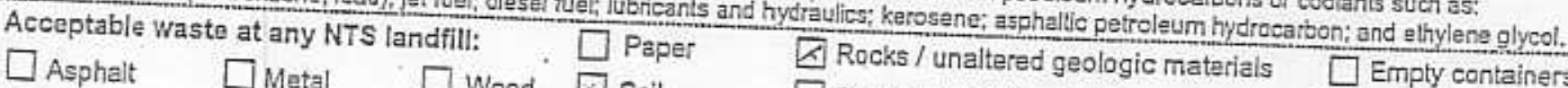
$\square$ Asphalt
$\square$ Plastic
$\square$ Metal
$\square$ Wire
$\square$ Wood
[S Soil
$\square$ Cable
Cloth
$\square$ Rubber (excluding tires)
$\square$ Insulation (non-Asbestosform)
$\square$ Empty containers
$\square$ Demolition debris
$\square$ Cement \& concrete

Manufactured items: (swamp coolers, furniture, rugs, carpef, electronic components, PPE, etc.)

Additional waste accepted at the Area 23 Mercury Landfill: $\square$ Office waste $\square$ Food Waste

Asbestos: $\square$ Friable $\square$ Non-Friable (contact SWo if regulated load) Quantity:

Additional waste accepted at the Area 9 U10c Landfill:

$\square$ Non-friable asbestos

Light ballasts (contact SWO)

Hydrocarbons (contact SWO)

Drained automobiles and military vehicles

Drained fuel filters (gas \& diesel)

(contact swo) $\square$ other

Additional waste accepted at the Area 6 Hydrocarbon Landfill:

$\square$ septic sludge $\square$ Rags

$\square$ Plants $\quad$ Soil

Area 6 Hydrocarbon Landfill:
Drained fuel filters (gas \& ciesel)

$\square$ sludge from sand/oil/water separators

Initials: $\mathrm{Za}$ (If initiaied, RO REQUIRED: WASTE GENERATOR SIGNATURE

The abova mentloned waste was oeneratod clearance is necessary.)

The above mentioned waste was generated outside of a Controlled Waste Management Area (CWMA) and to the best of my
knowledge, does not contain radiological materials.

To the best of my knowledge, the waste described above contains only those i site. Thave verified this through the waste charasterization methed identiiled a prohibited and allowable waste items.

Print Name: $\frac{\text { Ruginald A - Arumeion }}{\text { or }}$ Signatura:

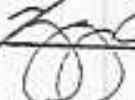

Date: $\frac{4 / 19 / 04}{1}$

Radiation Survey Release for Waste Disposal RCT Initials

This containerload is free of extemal radioactive contamination.

This containeriload is exemot from survey due to process knowledge and origin.

This container/ioad is free of radioactive

SIGNATURE:

Note: Food waste, difice tresh andior animal carcasses ara considered not to contait

require a radiological clearancs,

SWO USE ONLY

Load Welght (net from scale or estimate): 


\section{APPENDIX F}

\section{MODIFICATIONS*}

*Appendix F of the standardized outline for a Federal Facility Agreement and Consent Order Closure Report, Modifications, is not required for CAU 396. This appendix is not applicable to CAU 396: Area 20 Spill Sites. 
CLOSURE REPORT - CAU 396

Section: Appendix F

Revision: 0

Date: June 2004

THIS PAGE INTENTIONALLY LEFT BLANK 
CLOSURE REPORT - CAU 396

Section: Appendix G

Revision: 0

Date: June 2004

\section{APPENDIX G}

\section{PHOTOGRAPHS OF CLOSURE ACTIVITIES}


CLOSURE REPORT - CAU 396

Section: Appendix G

Revision: 0

Date: June 2004

THIS PAGE INTENTIONALLY LEFT BLANK 


\section{PHOTOGRAPHIC LOG}

\begin{tabular}{|c|c|c|}
\hline $\begin{array}{l}\text { PHOTOGRAPH } \\
\text { NUMBER }\end{array}$ & DATE & DESCRIPTION \\
\hline 1 & $4 / 15 / 2004$ & CAS 20-25-01 Excavation \#2 facing south. \\
\hline 2 & $4 / 15 / 2004$ & CAS 20-25-01 Excavation \#2 facing east. \\
\hline 3 & $4 / 15 / 2004$ & CAS 20-25-01 Excavation \#2 facing west. \\
\hline 4 & $4 / 15 / 2004$ & CAS 20-25-01 Excavation \#2 facing south (backfilled). \\
\hline 5 & $4 / 15 / 2004$ & CAS 20-25-01 Excavation \#2 facing east (backfilled). \\
\hline 6 & $4 / 15 / 2004$ & CAS 20-25-01 Excavation \#2 facing west (backfilled). \\
\hline 7 & $4 / 15 / 2004$ & CAS 20-25-01 Excavation \#1 facing south. \\
\hline 8 & $4 / 15 / 2004$ & CAS 20-25-01 Excavation \#1 facing east. \\
\hline 9 & $4 / 15 / 2004$ & CAS 20-25-01 Excavation \#1 facing west. \\
\hline 10 & $4 / 15 / 2004$ & CAS 20-25-01 Excavation \#1 facing south (backfilled). \\
\hline 11 & $4 / 15 / 2004$ & CAS 20-25-01 Excavation \#1 facing southwest (backfilled). \\
\hline 12 & $4 / 15 / 2004$ & CAS 20-25-01 Excavation \#1 facing west (backfilled). \\
\hline 13 & $4 / 15 / 2004$ & CAS 20-25-01 Entire site facing Southwest. \\
\hline 14 & $5 / 13 / 2004$ & CAS 20-25-02 facing west. \\
\hline 15 & $5 / 13 / 2004$ & CAS 20-25-02 facing north. \\
\hline 16 & $5 / 13 / 2004$ & CAS 20-25-02 facing east. \\
\hline 17 & $5 / 13 / 2004$ & CAS 20-25-02 facing south. \\
\hline 18 & $5 / 13 / 2004$ & CAS 20-25-02 Entire site facing west. \\
\hline 19 & $4 / 15 / 2004$ & CAS 20-25-03 Excavation \#2 facing east. \\
\hline 20 & $4 / 15 / 2004$ & CAS 20-25-03 Excavation \#2 facing south. \\
\hline 21 & $4 / 15 / 2004$ & CAS 20-25-03 Excavation \#2 facing west. \\
\hline 22 & $4 / 15 / 2004$ & CAS 20-25-03 Excavation \#2 facing north. \\
\hline 23 & $4 / 15 / 2004$ & CAS 20-25-03 Excavation \#2 facing east (backfilled). \\
\hline 24 & $4 / 15 / 2004$ & CAS 20-25-03 Excavation \#2 facing north (backfilled). \\
\hline 25 & $4 / 15 / 2004$ & CAS 20-25-03 Excavation \#2 facing south (backfilled). \\
\hline 26 & $4 / 15 / 2004$ & CAS 20-25-03 Excavation \#2 facing west (backfilled). \\
\hline 27 & $4 / 19 / 2004$ & CAS 20-25-03 Excavation \#1 facing west. \\
\hline
\end{tabular}




\section{PHOTOGRAPHIC LOG (CONT.)}

\begin{tabular}{|c|c|l|}
\hline $\begin{array}{c}\text { PhOTOGRAPH } \\
\text { NumbER }\end{array}$ & \multicolumn{1}{|c|}{ DATE } & \multicolumn{1}{|c|}{ DESCRIPTION } \\
\hline 28 & $4 / 19 / 2004$ & CAS 20-25-03 Excavation \#1 bottom. \\
\hline 29 & $4 / 19 / 2004$ & $\begin{array}{l}\text { CAS 20-25-03 Excavation \#1 breaking bottom rock layer w/ } \\
\text { hoe-ram. }\end{array}$ \\
\hline 30 & $4 / 19 / 2004$ & $\begin{array}{l}\text { CAS 20-25-03 Excavation \#1 breaking bottom rock layer w/ } \\
\text { hoe-ram }(2) .\end{array}$ \\
\hline 31 & $4 / 19 / 2004$ & $\begin{array}{l}\text { CAS 20-25-03 Excavation \#1 breaking bottom rock layer w/ } \\
\text { hoe-ram (3). }\end{array}$ \\
\hline 32 & $4 / 19 / / 2004$ & $\begin{array}{l}\text { CAS 20-25-03 Excavation \#1 facing north after hoe-ram } \\
\text { activities. }\end{array}$ \\
\hline 33 & $4 / 19 / 2004$ & CAS 20-25-03 Excavation \#1 bottom after hoe-ram activities. \\
\hline 34 & $4 / 19 / 2004$ & CAS 20-25-03 Excavation \#1 facing south (backfilled). \\
\hline 35 & $4 / 19 / 2004$ & CAS 20-25-03 Excavation \#1 facing north (backfilled). \\
\hline 36 & $4 / 15 / 2004$ & CAS 20-25-03 Excavation \#2 facing east (backfilled). \\
\hline
\end{tabular}




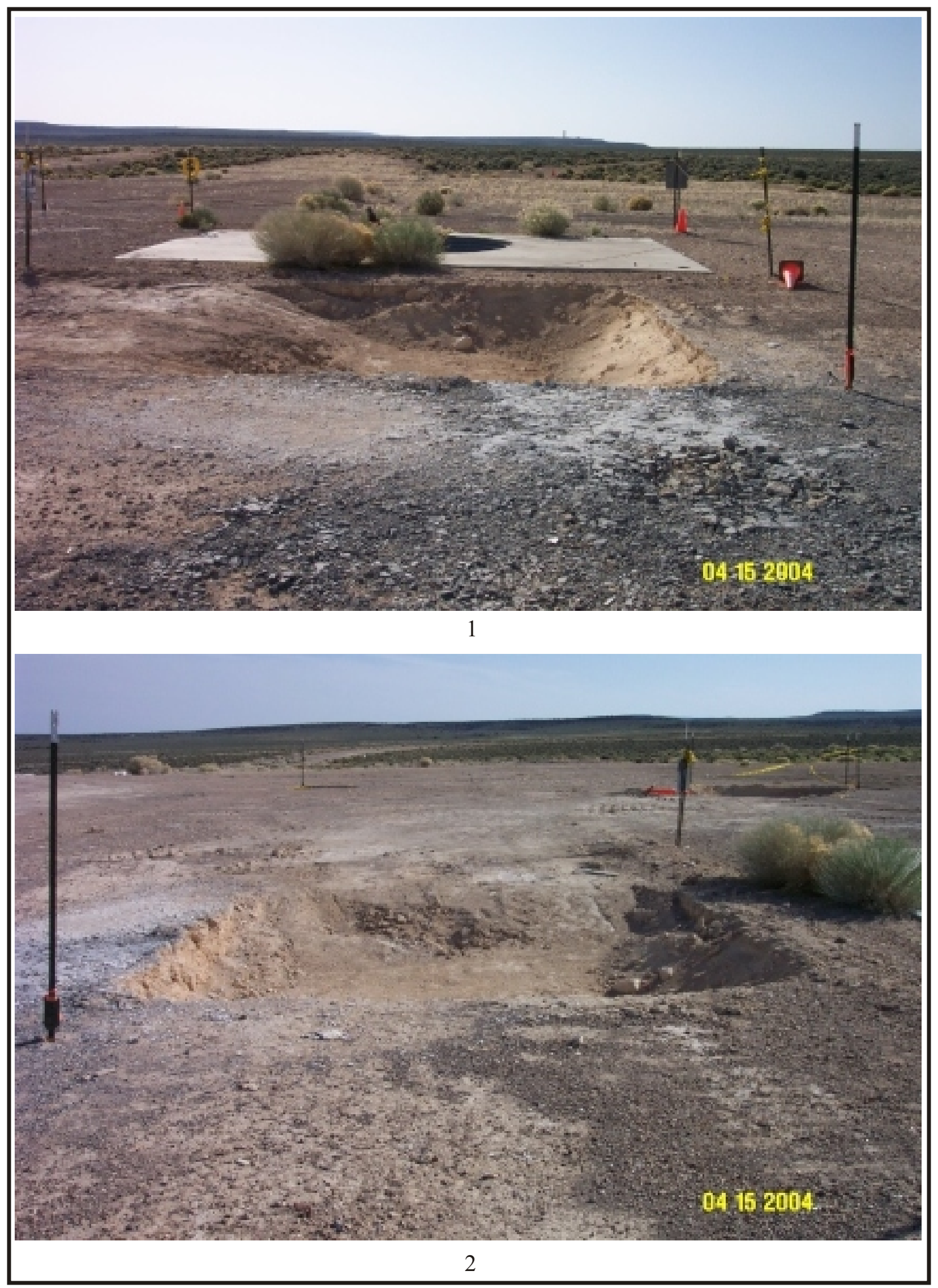




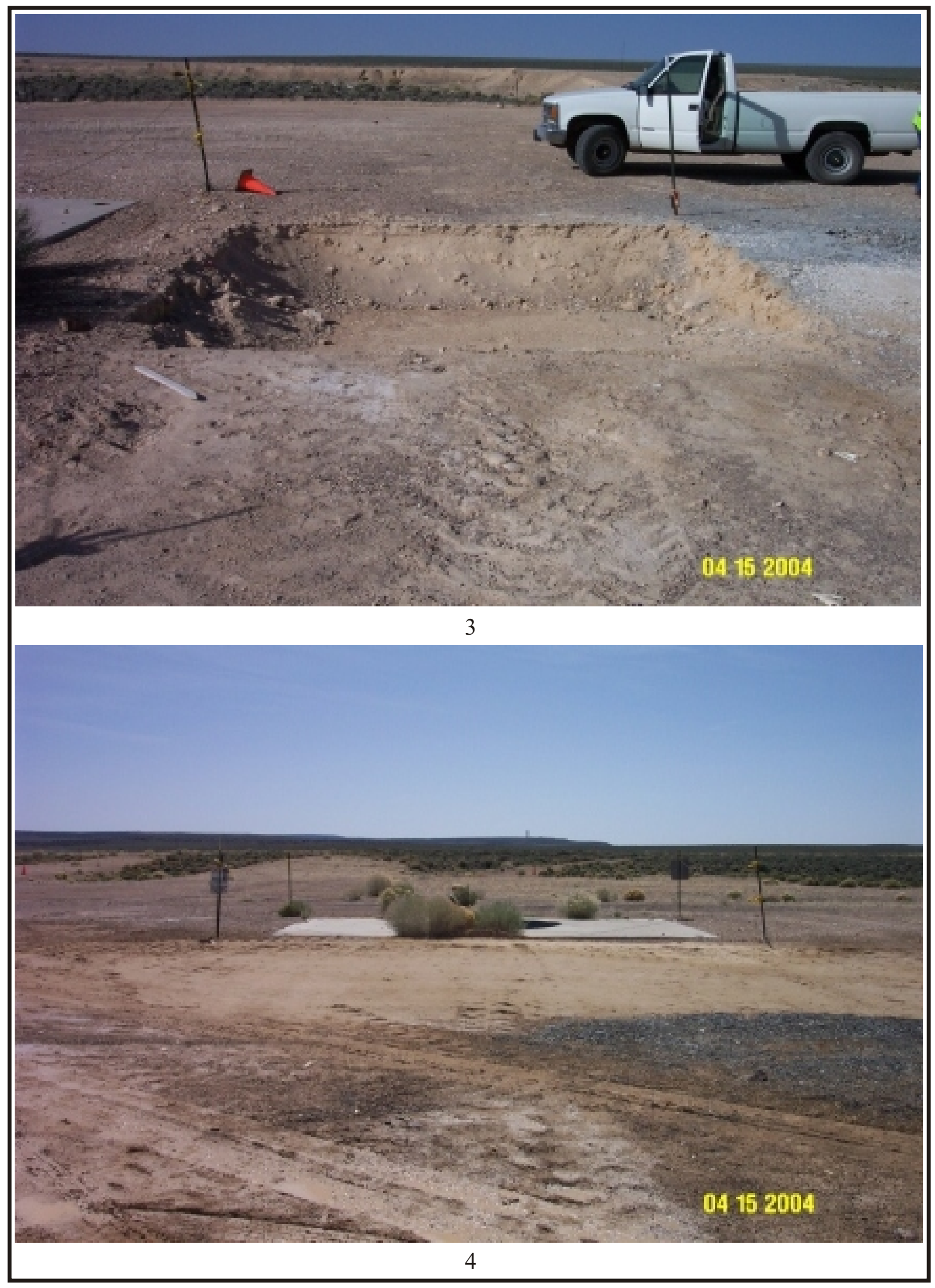




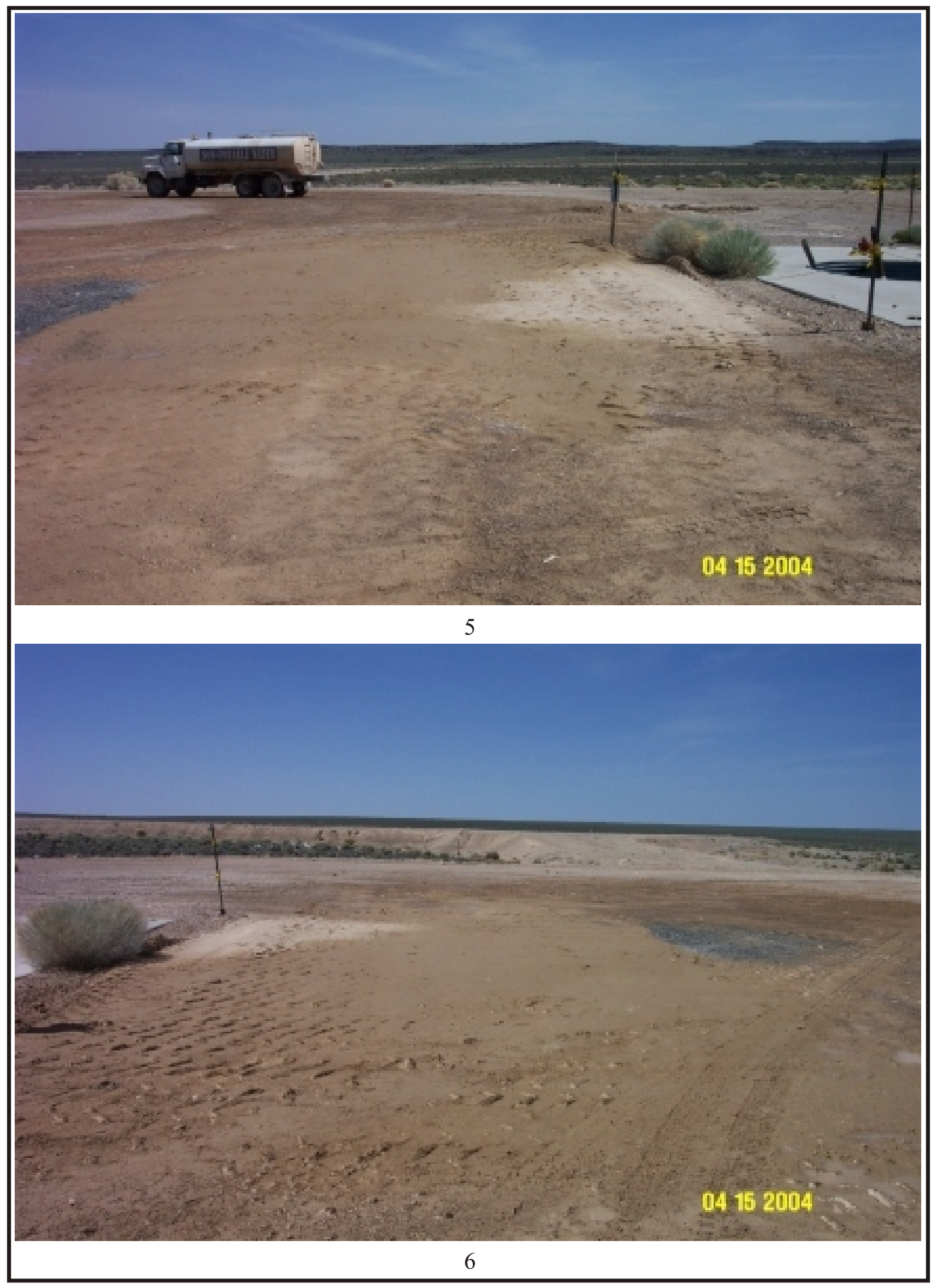




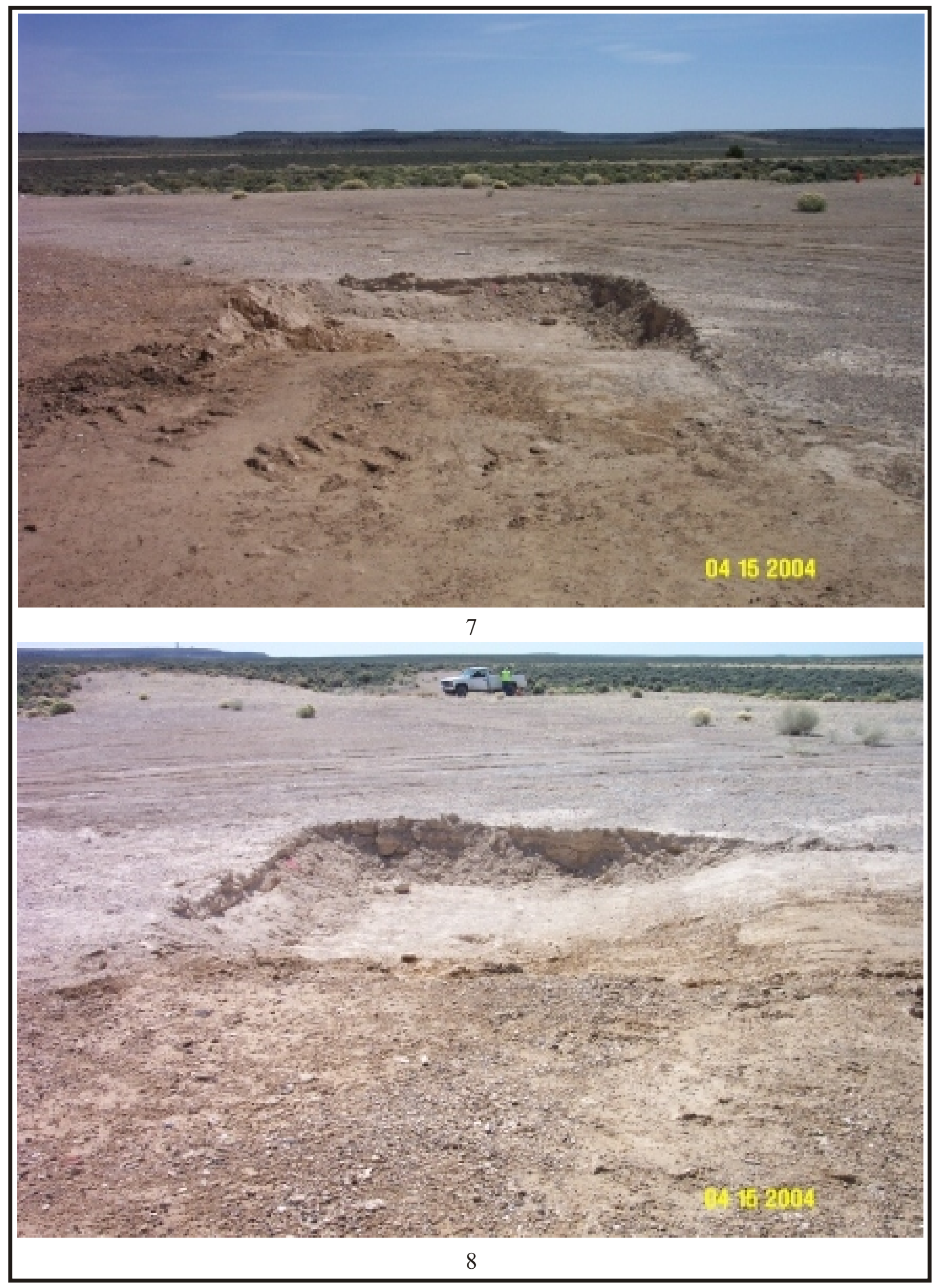




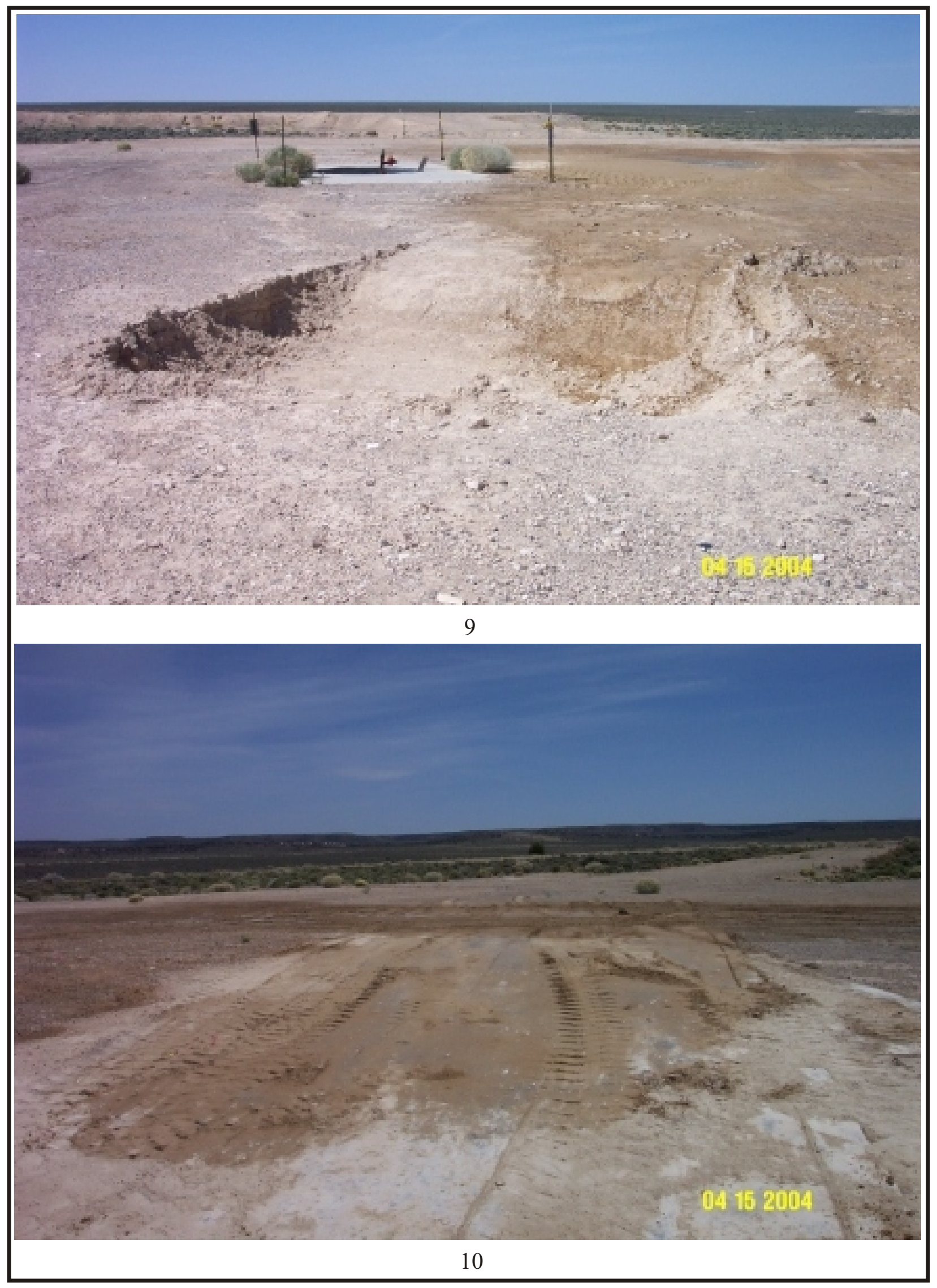




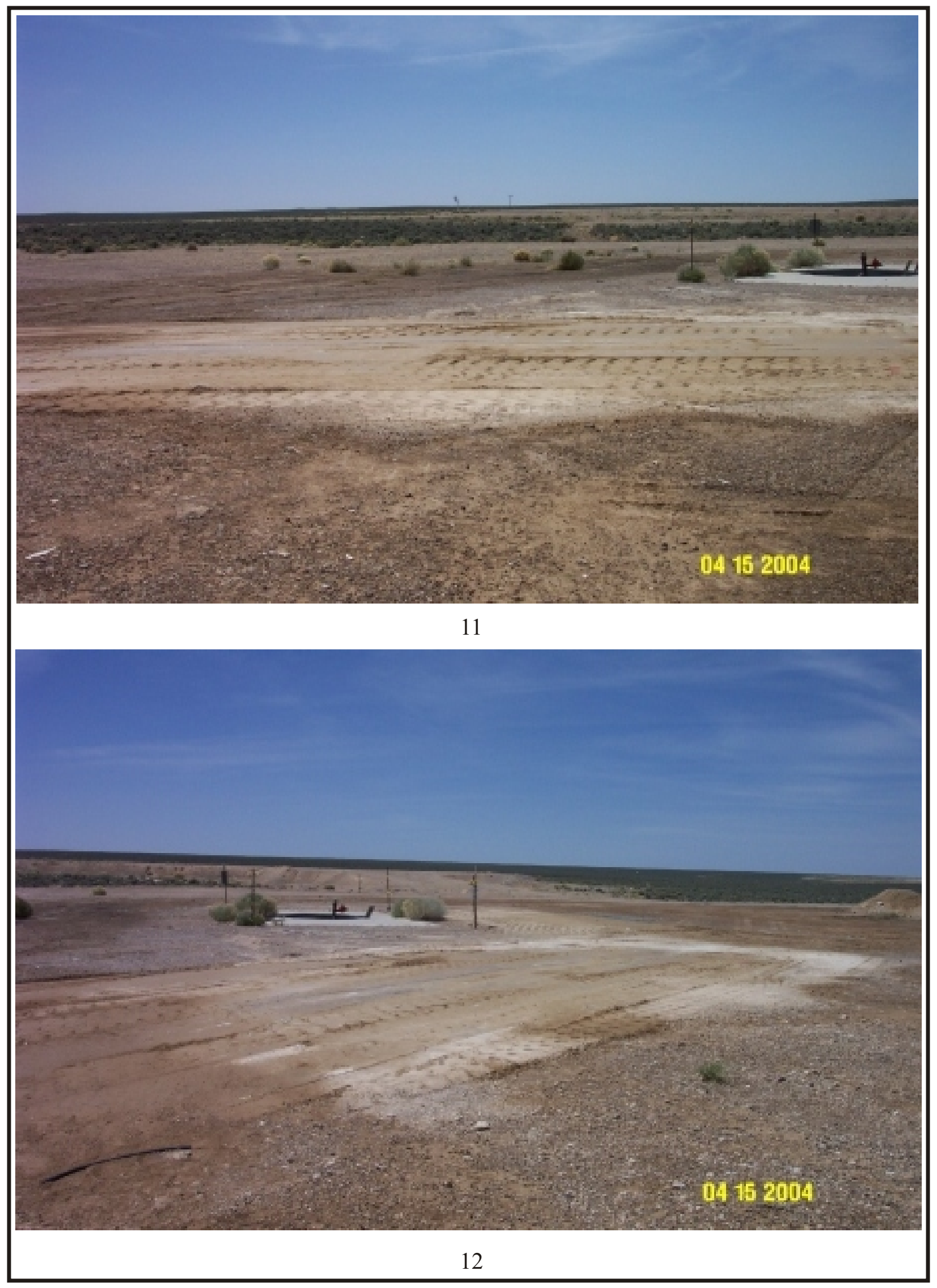




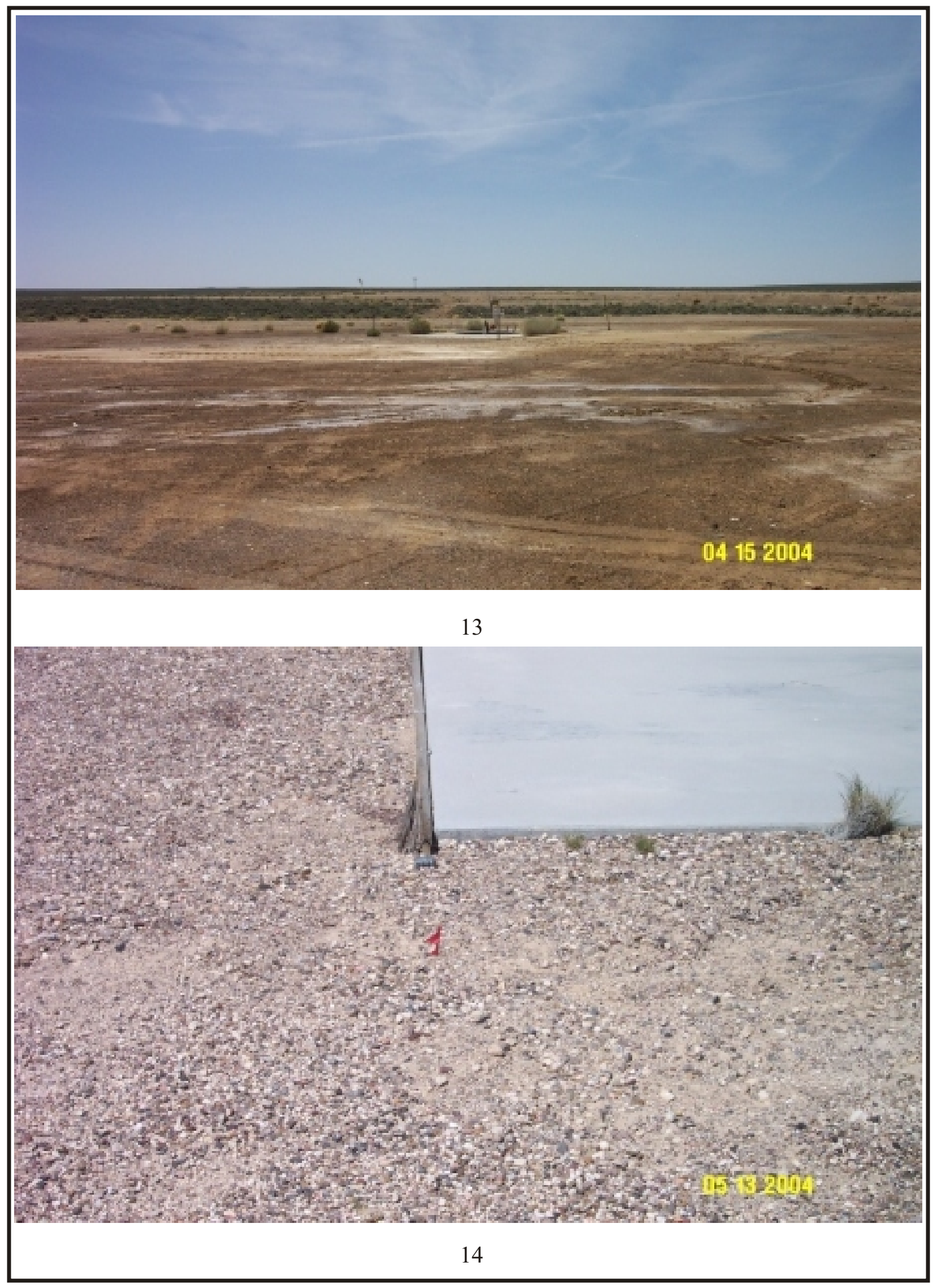




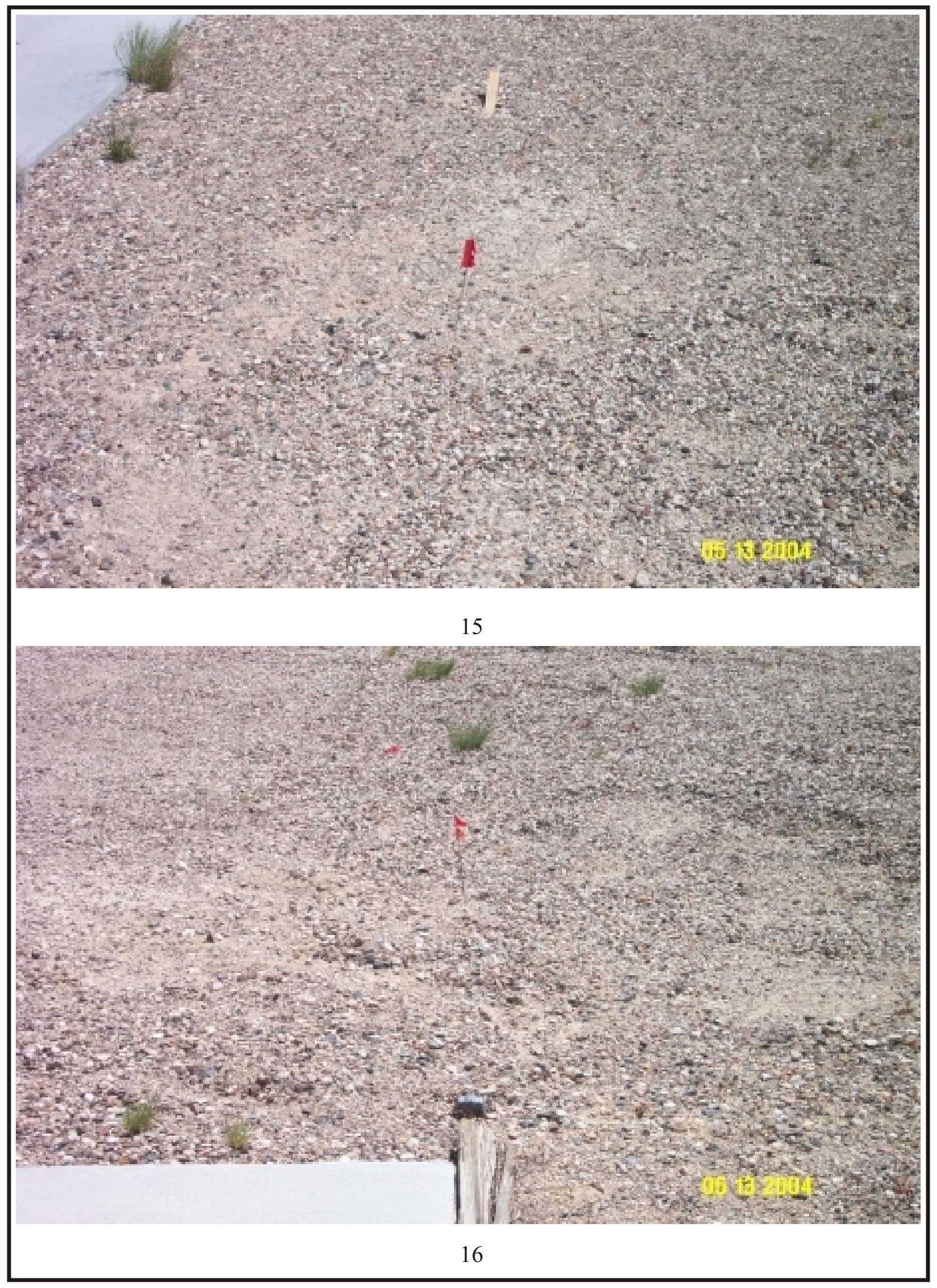




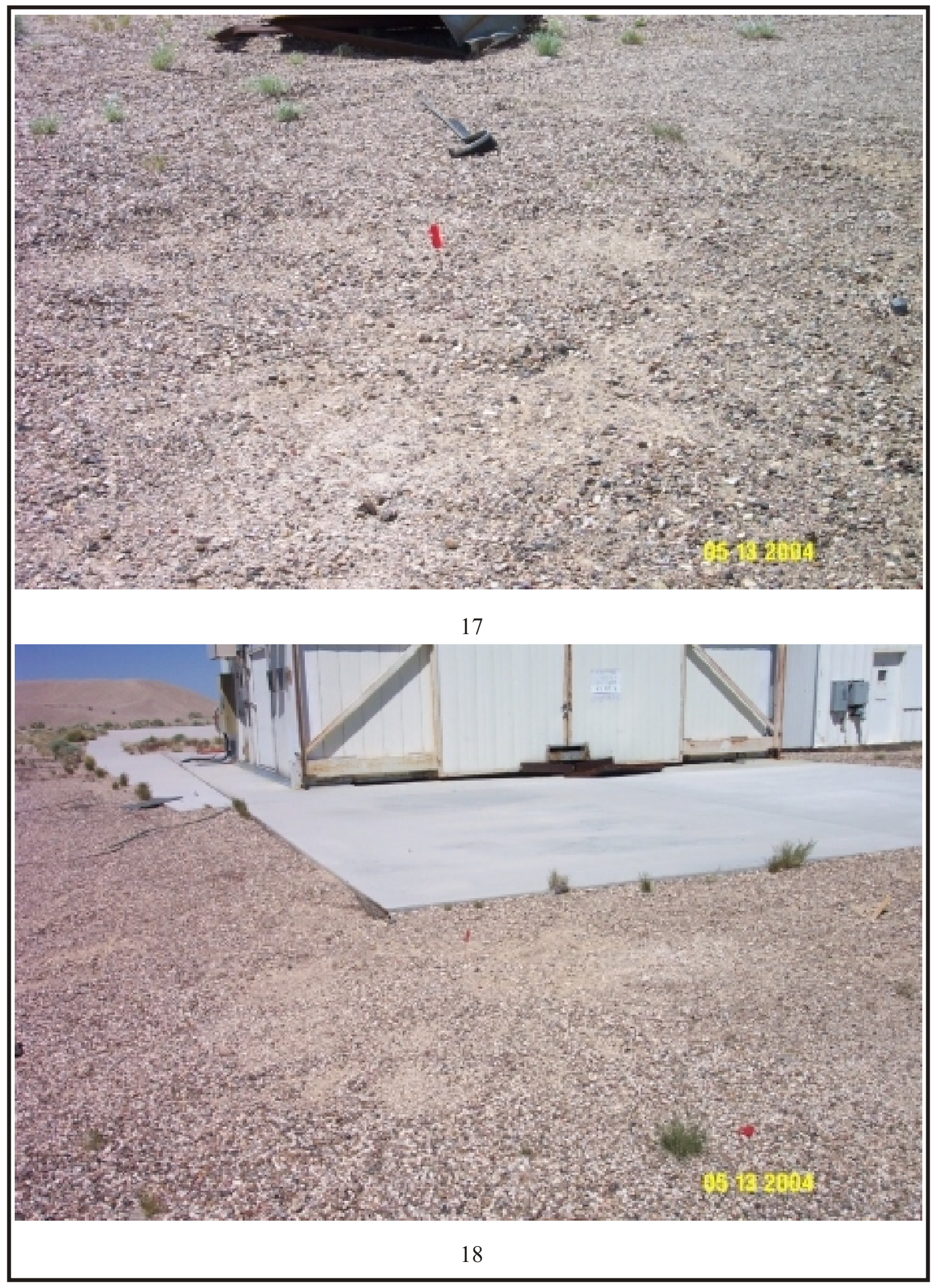




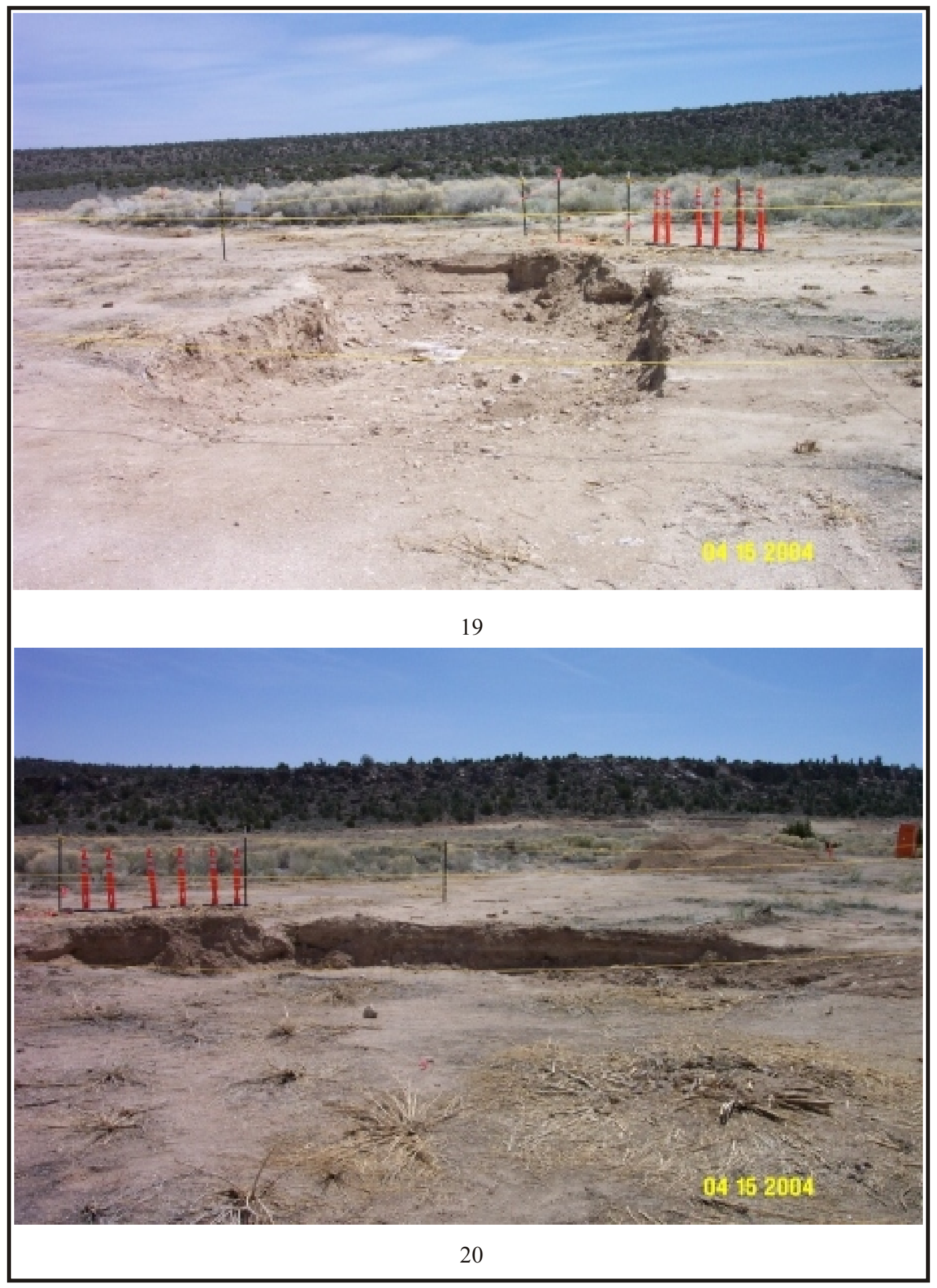




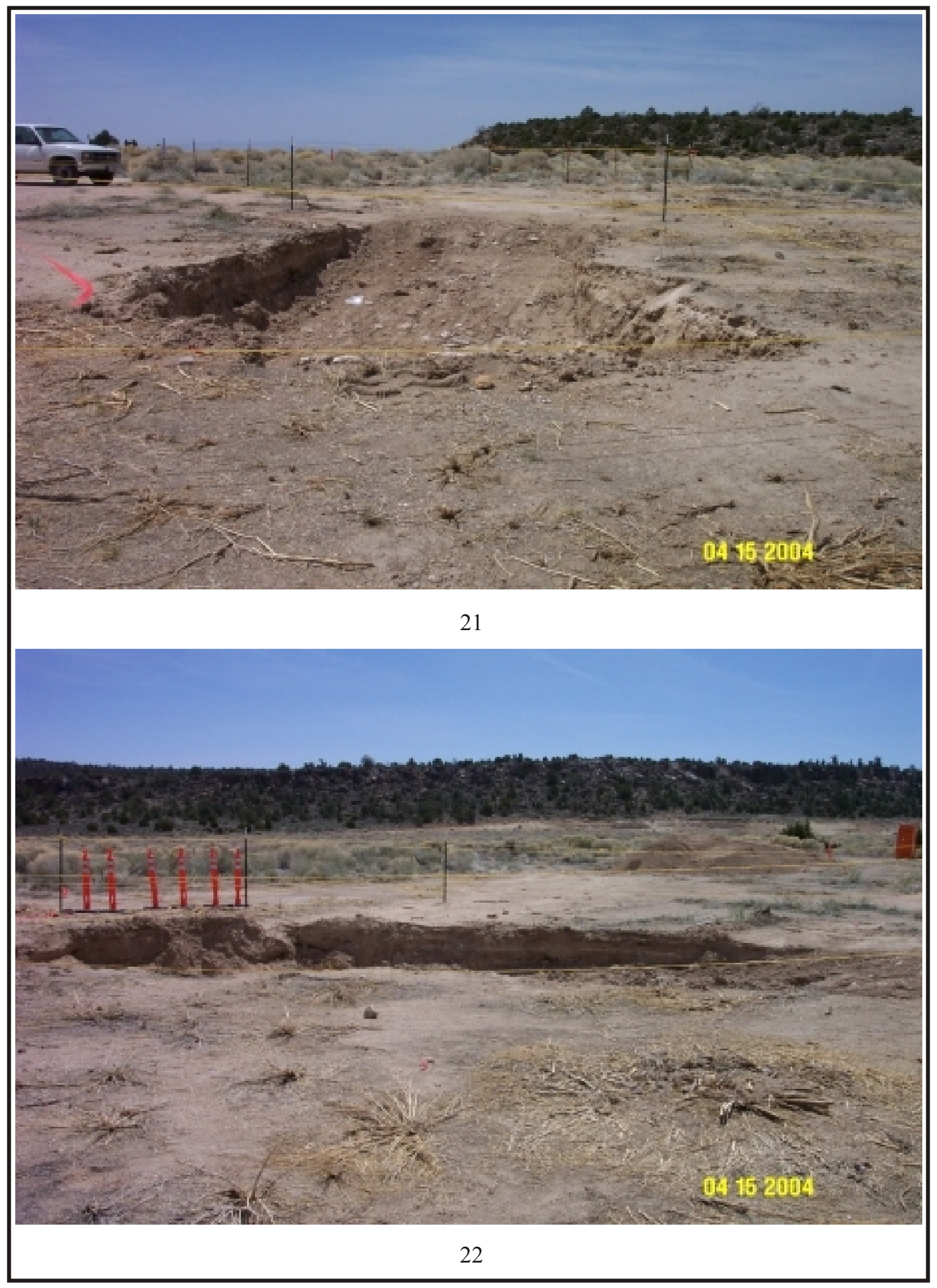




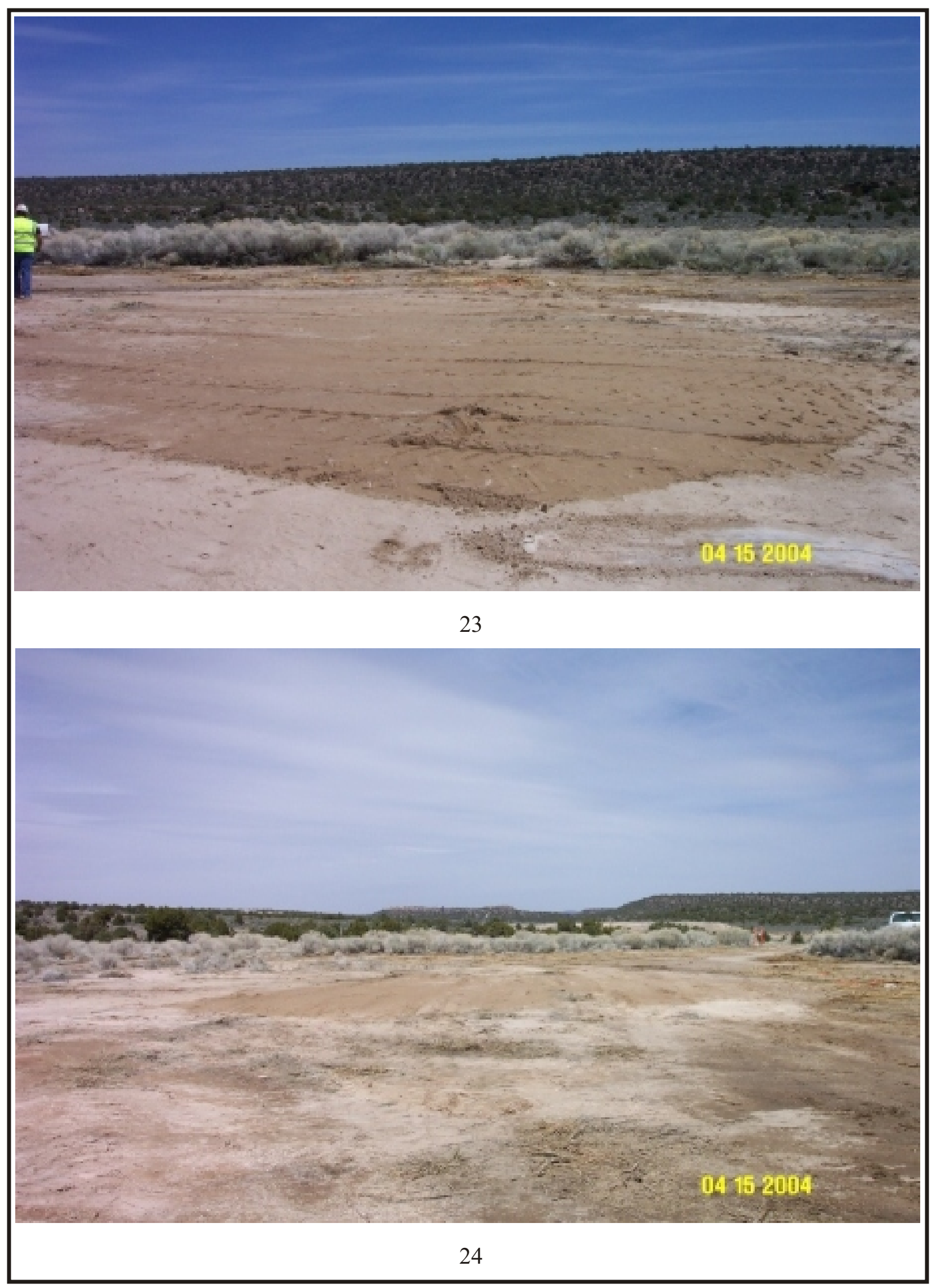




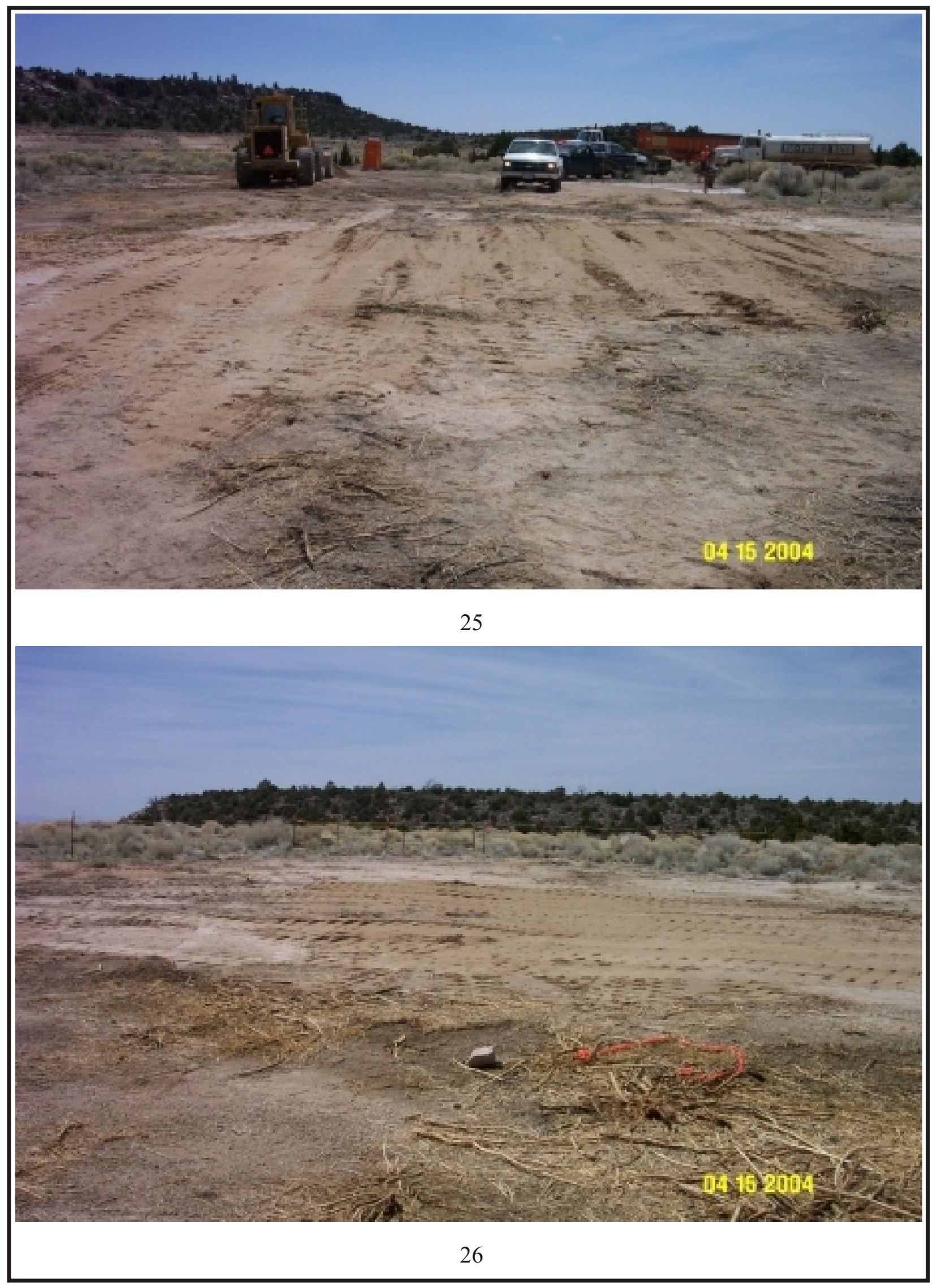




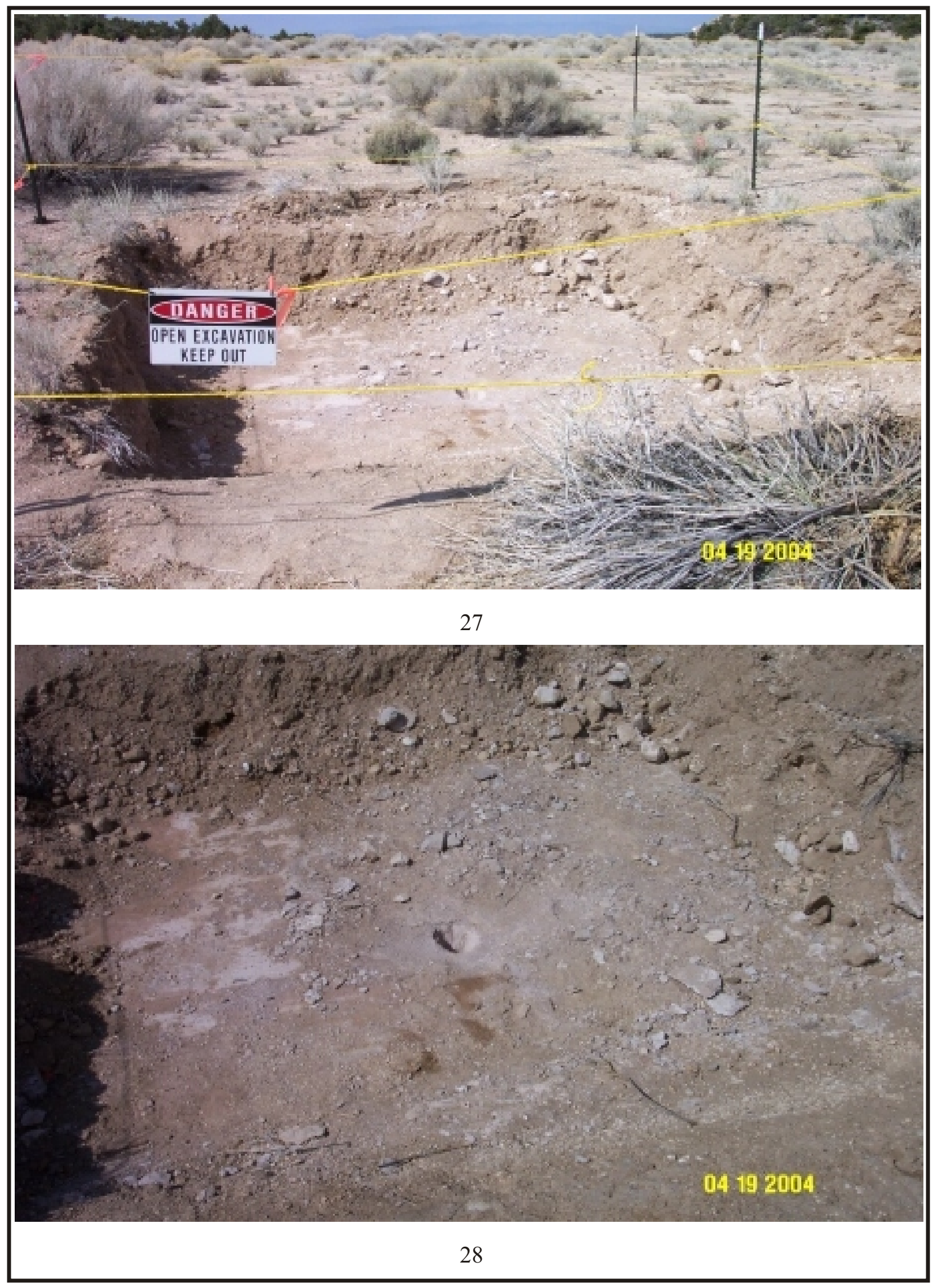




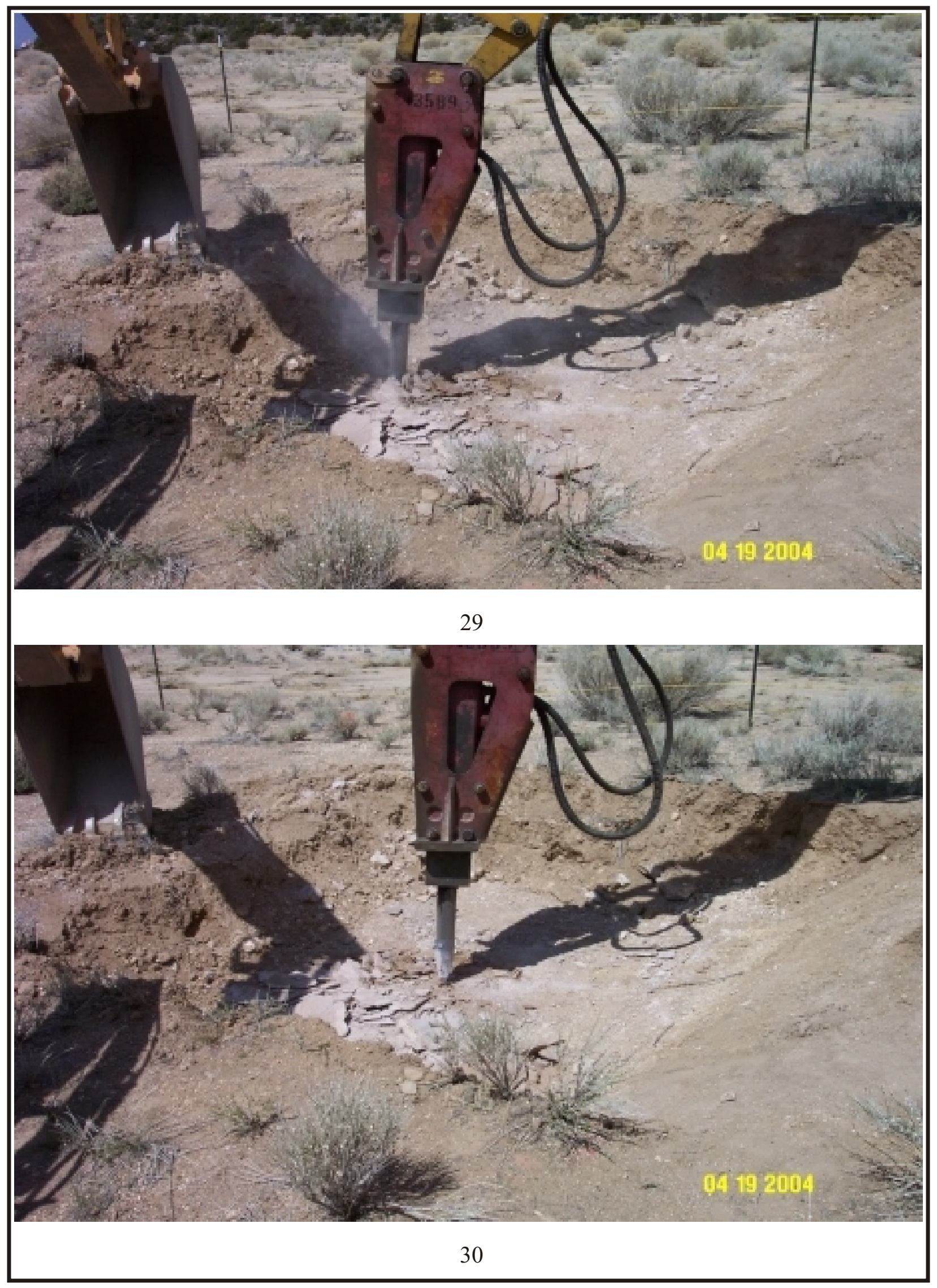




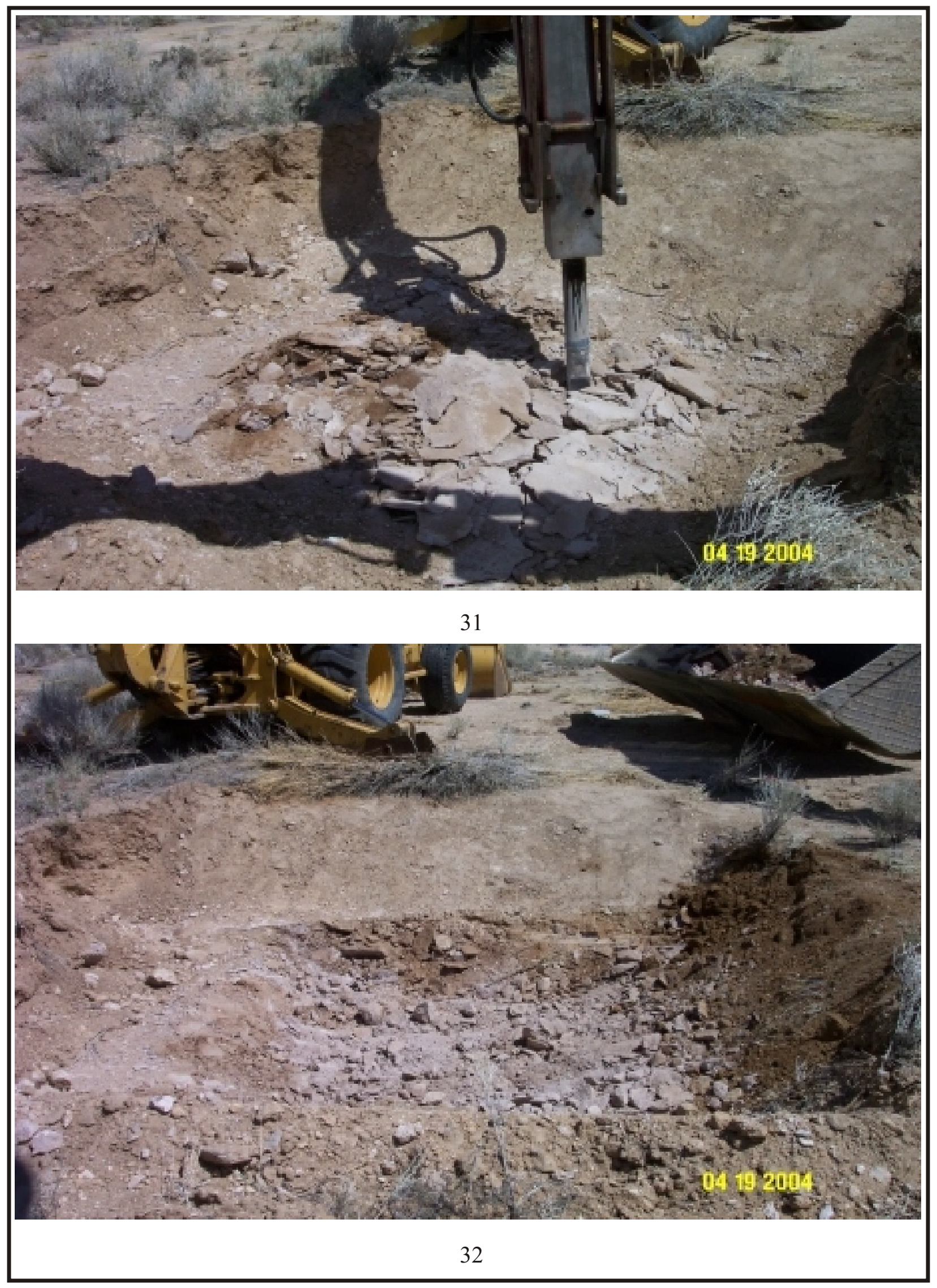




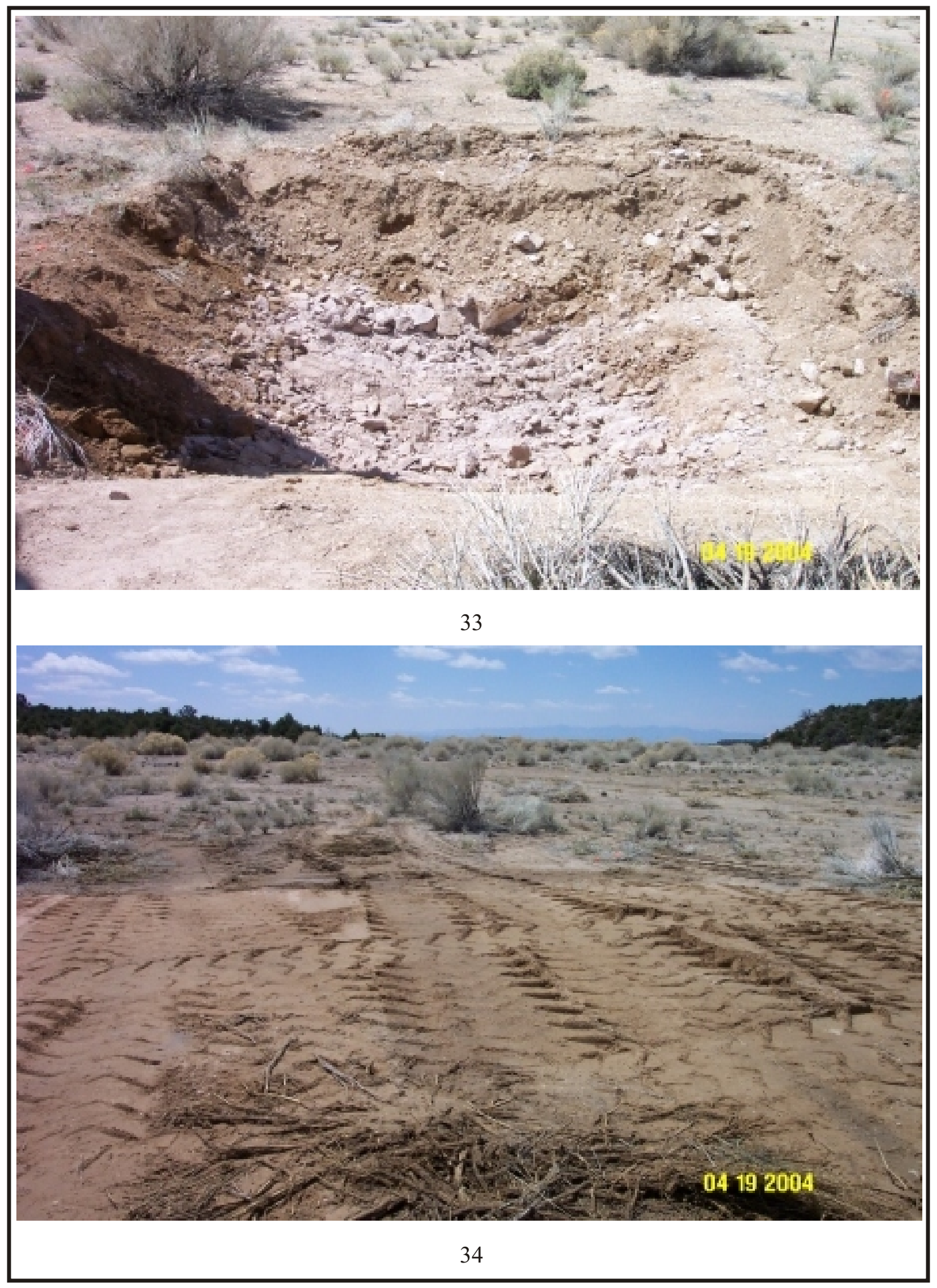




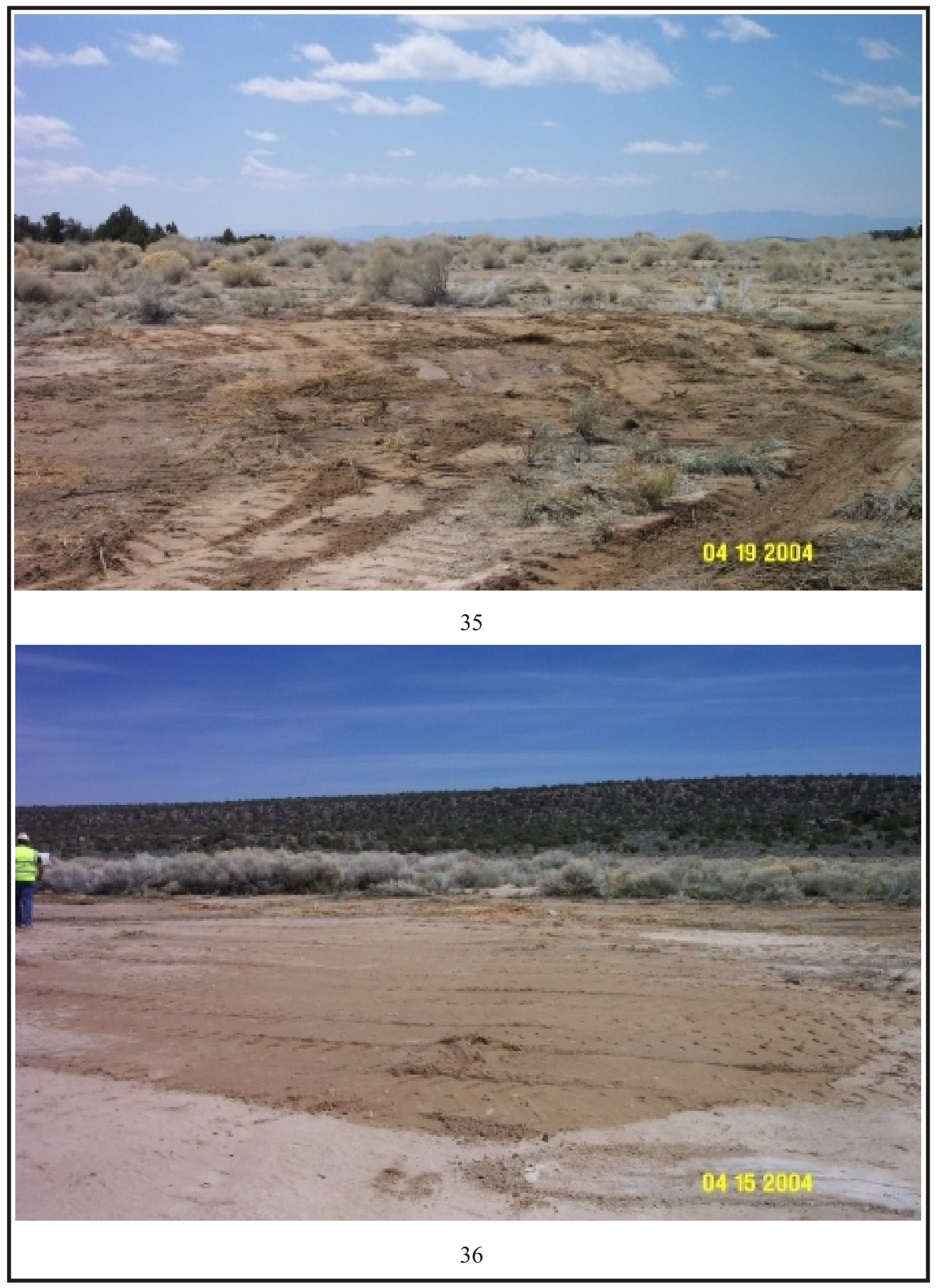


CLOSURE REPORT - CAU 396

Section: Library Distribution List

Revision: 0

Date: June 2004

\section{LIBRARY DISTRIBUTION LIST}


CLOSURE REPORT - CAU 396

Section: Library Distribution List

Revision: 0

Date: June 2004

THIS PAGE INTENTIONALLY LEFT BLANK 


\section{LIBRARY DISTRIBUTION LIST}

U.S Department of Energy

National Nuclear Security Administration

Nevada Site Office

Technical Library

P.O. Box 98518, M/S 505

Las Vegas, NV 89193-8518

U.S. Department of Energy

Office of Scientific and Technical Information

P.O. Box 62

Oak Ridge, TN 37831-0062

Southern Nevada Public Reading Facility c/o Nuclear Testing Archive1 (Uncontrolled)

P.O. Box 98521, M/S 400

Las Vegas, NV 89193-8521

Manager, Northern Nevada FFACO

Public Reading Facility

c/o Nevada State Library \& Archives

Carson City, NV 89701-4285
1 (Uncontrolled)

1 (Uncontrolled, electronic copy)

1 (Controlled)

1 (Uncontrolled) 
CLOSURE REPORT - CAU 396

Section: Library Distribution List

Revision: 0

Date: June 2004

THIS PAGE INTENTIONALLY LEFT BLANK 